UNIVERSIDADE DE SÃO PAULO

FACULDADE DE FILOSOFIA, LETRAS E CIÊNCIAS HUMANAS DEPARTAMENTO DE CIÊNCIA POLÍTICA PROGRAMA DE PÓS-GRADUAÇÃo EM CIÊNCIA POLÍTICA

THIAGO HINOJOSA BELMAR

\title{
Grupos de interesse e o processo de modernização do futebol brasileiro: da redemocratização ao Bom Senso Futebol Clube
}

DISSERTAÇÃO DE MESTRADO

Volume I

Versão corrigida

São Paulo 
THIAGO HINOJOSA BELMAR

\title{
Grupos de interesse e o processo de modernização do futebol brasileiro: da redemocratização ao Bom Senso Futebol Clube
}

Dissertação de Mestrado apresentada ao Programa de Pós-graduação em Ciência Política, da Universidade de São Paulo, como parte dos requisitos necessários à obtenção do título de Mestre em Ciência Política.

Orientador: Prof. Dr. Wagner Pralon Mancuso

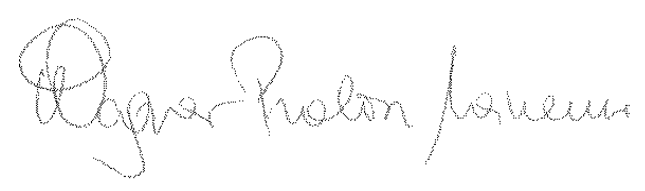

\author{
Volume I \\ Versão Corrigida
}

São Paulo

2016 
Aos que amam o futebol. 


\section{Agradecimentos}

Agradeço, primeiramente, ao meu orientador, Wagner Pralon Mancuso, pelas críticas, sugestões e pelo apoio de sempre. Também à banca de qualificação, composta por Sergio Praça e Bernardo Buarque de Holanda, que fizeram comentários essenciais para a dissertação.

Não poderia deixar de agradecer aos funcionários da secretaria de pós-graduação do Departamento de Ciência Política da USP, especialmente Vasne, Rai e Márcia. Sem a contribuição deles, nada disso seria possível.

Por fim, agradeço aos amigos Caio, Marília, Daniela, Davi e Daniel, pelo apoio que sempre me deram; à minha família (Airton, Leila, Bruna e Francisca) que sempre acreditou e nunca deixará de acreditar em mim; e à minha companheira de todos os momentos, principalmente dos mais difíceis, Ana Paula, a quem devo tudo. Não seria possível realizar essa dissertação sem seu apoio.

Muito obrigado a todos. 


\section{Resumo}

Esta dissertação aborda o tema do futebol, inserido na discussão teórica da ciência política, especialmente a que trata dos grupos de interesse, com destaque para a teoria das coalizões de defesa (Sabatier e Jenkins-Smith, 1999). Especificamente, é estudado o processo de "modernização" do futebol brasileiro, marcado pela transformação do esporte em uma atividade voltada para a visão do mundo dos negócios, envolvendo quantidades relevantes de dinheiro, ações de marketing, patrocínio de empresas e participação de investidores e empresários no meio futebolístico. Esse processo é abordado em torno de duas questões principais, a saber, a relação de trabalho entre clubes e atletas e a administração dos clubes. Uma torna o futebol uma atividade cada vez mais profissional, enquanto a outra traz a mentalidade empresarial para o esporte. São estudados momentos-chave deste processo, a partir da redemocratização da política brasileira, partindo da Lei Zico, passando pela Lei Pelé, Lei Maguito Vilela, CPIs do Futebol, Estatuto do Desporto, Timemania e Lei de Responsabilidade Fiscal do Esporte. Conclui-se que ocorreram mudanças significativas no futebol brasileiro, com o processo de modernização, mas que a atuação dos grupos de interesse foi fundamental para que algumas mudanças não ocorressem, que outras fossem adiadas e também para que algumas fossem efetivadas. 


\begin{abstract}
This dissertation deals with the football theme, inserted into the theoretical discussion of interest groups in political science, especially the theory of advocacy coalitions (Sabatier and Jenkins-Smith, 1999). Specifically, the process of "modernization" of Brazilian football, marked by the transformation of sport in a focused activity for the business world view is studied, involving significant amounts of money, marketing, corporate sponsorship and participation of investors and entrepreneurs among football. This process is covered in around two main issues, namely the working relationship between clubs and athletes and the management of clubs. The first makes football an increasingly professional activity, while the second brings a business mindset for the sport. Key moments of this process are studied, from the democratization of Brazilian politics, starting from the Zico Law, through the Pele Law, Maguito Vilela Law, Football's CPIs, Sports Statute, Timemania and Fiscal Responsibility Law of Sports. It was concluded that there were significant changes in Brazilian football, with the modernization process, but that the role of interest groups was essential for some changes did not occur, to others be delayed and also for some to take effect.
\end{abstract}


Lista de Figuras

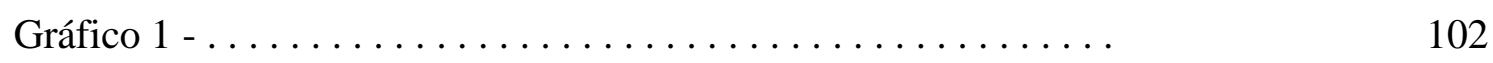




\section{Lista de Tabelas}

Tabela 1 -

Tabela 2 - 


\section{Conteúdo}

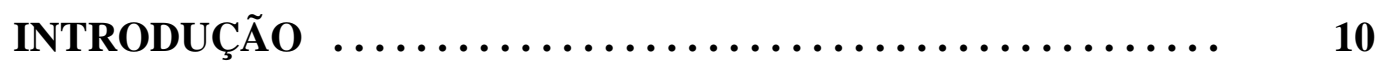

CAPÍTULO 1: LITERATURA E MÉTODO ............. 16

CAPÍTULO 2: HISTÓRICO DO FUTEBOL NO BRASIL ........ 24

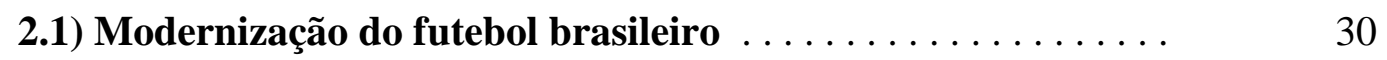

CAPÍTULO 3: MODERNIZAÇÃO DO FUTEBOL NO PROCESSO POLÍTICO ........................... 35

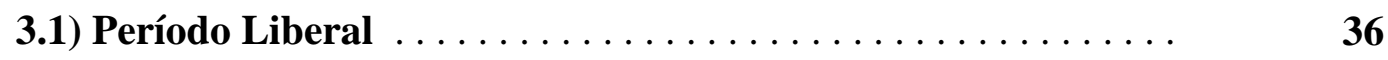

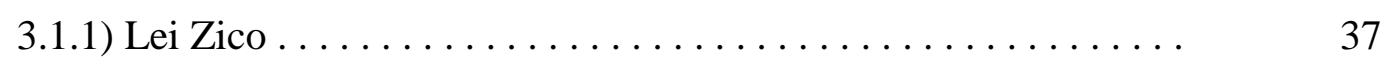

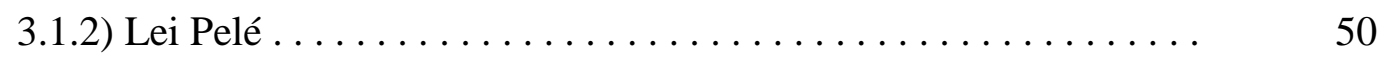

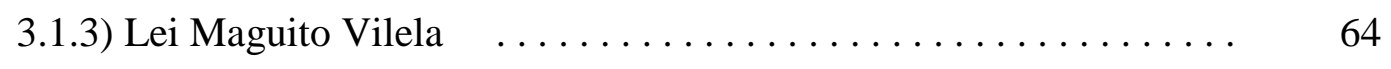

3.1.4) CPIs do Futebol . . . . . . . . . . . . . . . . . 69

a) CPI da CBF/Nike na Câmara dos Deputados ............. 69

b) CPI do Futebol no Senado $\ldots \ldots \ldots \ldots \ldots \ldots \ldots \ldots \ldots$

3.2) Período Regulatório $\ldots \ldots \ldots \ldots \ldots \ldots \ldots \ldots \ldots \ldots \ldots$

3.2.1) Estatuto do Desporto e Projeto de Lei 5186/05 . . . . . . . 85

3.2.2) Timemania . . . . . . . . . . . . . . . . . . . . 99

3.2.3) Lei de Responsabilidade Fiscal do Esporte . . . . . . . . . . . . . 104

CAPÍTULO 4: GRUPOS DE INTERESSE E MODERNIZAÇÃO DO FUTEBOL BRASILEIRO ....................... 110

4.1) Os grupos de interesse envolvidos $\ldots \ldots \ldots \ldots \ldots \ldots \ldots \ldots$

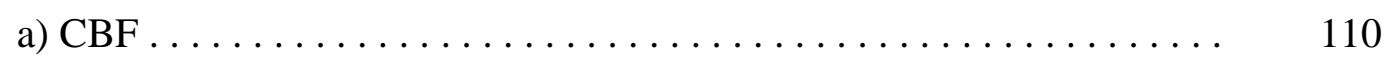

b) Federações estaduais . . . . . . . . . . . . . . . . . . 111

c) Clubes . . . . . . . . . . . . . . . . . . . . . . . 112

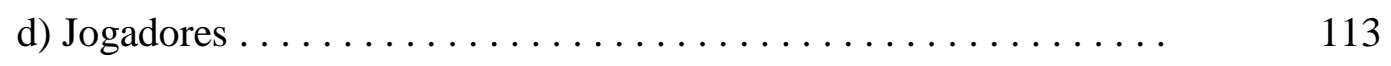

e) Meios de comunicação $\quad \ldots \ldots \ldots \ldots \ldots \ldots \ldots \ldots \ldots . \ldots \ldots . \ldots \ldots$

4.1.2) Bancada da Bola $\ldots \ldots \ldots \ldots \ldots \ldots \ldots \ldots \ldots \ldots \ldots . \ldots \ldots$

4.2) Atuação dos grupos de interesse . . . . . . . . . . . . . . . 119

CONSIDERAÇÕES FINAIS $\ldots \ldots \ldots \ldots \ldots \ldots \ldots \ldots \ldots \ldots \ldots$

REFERÊNCIAS BIBLIOGRÁFICAS ............... 135 


\section{Introdução}

O esporte é um fenômeno cultural com lógica e história próprias, e pode ser entendido como um conjunto de práticas e consumos oferecidos a agentes sociais por instituições para cumprir alguma demanda social (Bourdieu, 1983). Pode ser praticado tanto de forma livre, bem como um espetáculo de massas. Ele pode criar espaços de sociabilidade, nas interações que se dão nos clubes, entre atletas, ou entre associados, e na identificação que acaba sendo criada com os elementos pertencentes ao clube. Mas pode ir além e se tornar um evento com caráter de espetáculo e, a partir daí, entrar na lógica da comercialização (Haag, 2013), que pode ser cada vez mais intensificada, tornando o fenômeno praticamente todo voltado para a mercantilização e para atividades voltadas para a geração de lucro, por meio de diferentes estratégias, como a utilização do marketing (Gonçalves e Carvalho, 2006). Um esporte que se destaca bastante nesse tipo de desenvolvimento, e que será alvo desta dissertação, é o futebol, que começa a ser praticado de forma amadora, logo passa a se tornar uma atividade profissional e, cada vez mais, se torna atração de forças econômicas e políticas.

Esta dissertação aborda, amplamente, o futebol como tema de estudo. Dentro do futebol, o interesse principal é analisar um processo de "modernização" do futebol brasileiro, caracterizado por transformações no esporte que o levaram de um fenômeno restrito ao lazer e à competição esportiva, ligado à paixão pelos clubes, para um fenômeno correspondente ao mundo do entretenimento, cada vez mais tomado pelo marketing e pelos negócios, envolvendo quantias relevantes de dinheiro, transformando aquilo que era apenas lazer, competição e paixão em atividade lucrativa e profissional, inclusive sendo foco de esquemas de corrupção, desvios de dinheiro, enriquecimento ilícito de dirigentes, estelionato, etc. ${ }^{1}$

\footnotetext{
${ }^{1}$ Como relatado nos mais diversos meios de comunicação, como em: Escândalo derruba presidente da Fifa. Folha de São Paulo, 3 de junho de 2015. Número 2 da Fifa é elo de propina, diz jornal. Folha de São Paulo, 2 de junho de 2015. Corrupção no futebol põe na prisão ex presidente da CBF e 7 dirigentes. Folha de São Paulo, 28 de maio de 2015.
} 
A proposta é analisar o processo de modernização, através de dois de seus aspectos sobressalentes, que representam seu movimento transformador, a saber: as relações de trabalho entre clubes e atletas, que aproximou $o$ futebol ao profissionalismo, equiparando os jogadores aos trabalhadores comuns; e a administração dos clubes de futebol, que trouxe o esporte para mais perto do mundo dos negócios, passando de algo amador, de pequenas receitas, que pouco se envolvia com questões tributárias, para algo que passou a movimentar muito dinheiro, a gerar lucro, atrair investidores e, por consequência, ações de marketing, passando a se tornar um negócio, e, por tal, se envolvendo em questões tributárias, mudando sua relação com o Estado, sendo cada vez mais alvo deste, no sentido de ser cobrado por ele para que fosse taxado de acordo com a nova realidade.

No entanto, não se estudam esses elementos de maneira geral. Há um recorte e um contexto teórico que permeia a análise. Especificamente, o recorte foi estudar como entram os grupos de interesse no desenvolvimento desses dois elementos pertencentes ao mundo do futebol. Estes elementos reúnem uma série de atores com interesses distintos e que lutam por eles de acordo com seus recursos. Então, como os diferentes grupos de interesse atuam em cada uma dessas áreas? Qual o tamanho da influência, ou da responsabilidade deles nas decisões tomadas pelos diferentes âmbitos do poder político brasileiro nas questões que dizem respeito às relações de trabalho entre jogadores e clubes, e também à administração dos clubes de futebol nacionais?

O trabalho de Hirata e Junior (2014) a respeito da atuação dos grupos de interesse durante a tramitação do projeto que culminou com a lei Pelé é uma das poucas tentativas (se não a única), ao menos na ciência política, de estudar as mudanças ocorridas no futebol por esse aspecto, ressaltando o papel da política e dos grupos envolvidos nela. Os autores se valem de documentos oficiais referentes à tramitação do projeto para identificar a participação dos grupos e argumentam que, de fato, houve atuação, mas que os documentos não mostram um papel decisivo daqueles. A intenção aqui é dialogar com tal trabalho, reconhecendo a característica inovadora do artigo, ao procurar entender a participação dos grupos de interesse num

José Maria Marin está entre dirigentes da Fifa presos na Suíça. BBC Brasil, 27 de maio de 2015. 
processo legislativo relativo ao futebol, e buscando complementar tal estudo, utilizando não apenas as informações encontradas nos documentos oficiais, mas também em fontes secundárias importantes, como os relatos de meios de comunicação da época, e expandindo a análise para eventos relevantes posteriores à aprovação da lei Pelé, como o próprio artigo sugere, em seu fechamento.

Em primeiro lugar, deve-se saber o que aconteceu em todo o processo de mudança no futebol brasileiro. Quais foram as transformações ao longo do desenvolvimento do esporte no Brasil e quais foram os momentos-chave que provocaram alterações? Quais foram os atores que idealizaram as mudanças? Instituições foram utilizadas nesse sentido? As mudanças propostas inicialmente foram efetivadas conforme idealizadas? Se sim, por quais motivos? Quem foi determinante para que o desenrolar dos eventos se desse como tal? Se não, por quê? Quais atores foram relevantes, ou determinantes, para que as mudanças não ocorressem, ou ocorressem parcialmente, com uma série de contrapartidas? Que meios esses atores utilizaram?

Após verificar o que aconteceu ao longo do processo, importa explicar como e por quê. Responder às perguntas que aparecem conforme se revelam os acontecimentos. O que a pesquisa propõe é que houve, sim, transformações importantes nas duas áreas que abrangem a modernização do futebol brasileiro, que é foco do estudo. O futebol passou por uma série de mudanças, em todo o mundo, acompanhando as dinâmicas sociais e econômicas, especialmente do sistema capitalista e do processo de globalização, e no Brasil não foi diferente.

Será trabalhada a hipótese de que a determinante das mudanças, e dos vetos a elas, foi a atuação de diferentes grupos de interesse. O que será defendido é que, ao longo do período estudado, o processo de modernização do futebol brasileiro se intensificou, passando por medidas iniciais, ainda fora do contexto da política, como inserção de patrocínios, exposição de marcas, transmissões de televisão, ações de marketing e negociações milionárias de jogadores, sendo, posteriormente, alvo de discussões dentro do processo político, desde a lei Zico até atualmente, abarcando decisões tomadas pelos atores políticos, mas que foram, em muitos casos, influenciadas pelas ações de grupos de interesse de diferentes ordens. O discurso, ao longo do tempo, no futebol brasileiro, seguindo o caminho de países europeus, passou 
por uma mudança no sentido de aproximar o esporte ao mundo dos negócios e à forma de administrá-lo ao modo empresarial. Inicia-se esse discurso com as mudanças significativas ocorridas na década de 1980, que inserem o futebol no mundo do capital, e, de acordo com os acontecimentos e os momentos-chave que diziam respeito a essa questão, tanto no meio político como apenas no meio futebolístico, forma-se um novo paradigma, completamente voltado para a modernização de tal esporte que, ao menos na sua forma mais visível, integra-se totalmente ao mundo do marketing e dos negócios, afetando, inclusive, a forma de torcer para os clubes e pela seleção.

Nesse sentido, a hipótese é que os grupos de interesse foram determinantes desse resultado, de formas diferentes quanto aos dois eixos da modernização aqui analisados, porém, de qualquer maneira, mesmo que de forma mais truncada e lenta em determinados casos do que em outros, promovendo mudanças importantes. Não significa dizer que os esforços no sentido de barrar ou adiar certas alterações não tenham sido importantes. Pelo contrário, são muito importantes e também será atribuído aos grupos o sucesso nesses esforços.

No caso das relações de trabalho, a hipótese é que houve uma convergência de interesses envolvendo o Estado, parte da imprensa e entidades representantes de jogadores de futebol, que resultou em mudanças significativas em tal âmbito, ainda que depois de muita luta e de muita resistência, vinda de outra convergência de interesses, formada por dirigentes de clubes, federações e da CBF. Os clubes, as federações e a CBF, por meio de reuniões internas e com o governo, e da proximidade com parlamentares, com doações para campanhas, conseguiram prorrogar prazos para a entrada em vigor de algumas medidas desfavoráveis, amenizar alguns pontos delas, como a adoção de indenizações nas transferências de atletas para outros clubes, mas, em geral, perderam mais do que ganharam, pois o passe foi extinto. Por outro lado, governo, jogadores e associações relacionadas a eles mais ganharam do que perderam, pois o governo propôs o fim do passe e conseguiu aprovar a medida, que favoreceu os jogadores, que atuaram através da formação de entidades para defesa de seus interesses, reuniões com o governo e parlamentares e ainda contaram com o apoio de jornalistas. 
Já na questão da administração dos clubes, a hipótese é que as disputas envolvendo diferentes interesses foram muito mais acirradas. Trabalhou-se muito e conseguiu-se, em diversos momentos, por vezes adiando ou amenizando, provocar decisões desfavoráveis às grandes transformações, principalmente pela atuação dos clubes e da CBF, no sentido de tentar manter o status quo, ainda que tivessem que acatar pequenas mudanças para que ele fosse mantido. Estes grupos, se relacionando de maneira muito próxima com parlamentares, doando dinheiro para campanhas políticas, se reunindo internamente, assim como com o governo, e, se aproximando fortemente com a TV Globo, conseguiram benefícios fiscais e parcelamento de dívidas, sem ter de arcar com grandes contrapartidas e sem sofrer sanções rigorosas. Os jogadores e associações não conseguiram grandes vitórias perante aos clubes nessa área. Foi criado um movimento de representantes de destaque da categoria, o Bom Senso FC, cujos esforços ainda têm resultados incertos, pois as disputas ainda estão em andamento. As grandes vitórias não vieram de forma explícita, na prática, mas o discurso de que o futebol e os clubes devem ser administrados como empresas e deve ter dirigentes que tenham tal mentalidade cresceu bastante e ainda cresce, inclusive em novas gerações dos próprios dirigentes de clubes, que se voltam contra federações, contando com o apoio de diversos meios de comunicação, que se mostram, constantemente, favoráveis a mudanças desse tipo, juntamente com essa nova organização dos atletas. Há de se acompanhar como se darão os resultados das discussões atuais, que preveem uma lei mais rigorosa aos dirigentes de clubes, de federações e da CBF.

Os dois aspectos se dão de forma conjunta, dentro do processo de "modernização" e, a pesquisa, através deles, mostrará que houve um processo de mudança no futebol brasileiro, que trouxe a formação de um novo paradigma, o de tornar o esporte um bom negócio. No entanto, esse processo se deu ao longo de muitos anos, muito porque alguns grupos de interesse resistiram a ele, atuando para barrar medidas importantes nas arenas decisórias e obtendo vitórias e derrotas durante esse período. Portanto, tanto a atuação de grupos a favor das mudanças, quanto de grupos contra elas foram decisivos para a configuração dos resultados finais do processo de mudança no futebol no Brasil.

O caminho a ser percorrido no texto é, primeiramente, situar o fundo teórico que será explorado para entender o caso empírico, na revisão de literatura. Depois, é 
debatida a metodologia utilizada na pesquisa, seguida de um histórico sobre o futebol no Brasil, desde sua origem amadora até a intensa inserção no mundo dos negócios, com uma seção dedicada ao processo de modernização do futebol no país. Em seguida, discutem-se, em um capítulo, o tema principal analisado, com seus dois aspectos principais, dividido em fases diferentes, subdivididas, em primeiro lugar a fase chamada aqui de liberal (redemocratização a FHC 2), compreendendo os momentos-chave da Lei Zico, da Lei Pelé, da Lei Maguito Vilela, e das CPIs do futebol; posteriormente, a fase denominada aqui de regulatória (Lula a Dilma 1), que abrange os momentos-chave do Estatuto do Desporto, da Timemania e da Lei de Responsabilidade Fiscal do Esporte. Por fim, considerações finais apresentam uma análise, com base no que foi visto da atuação dos grupos de interesse no capítulo anterior, utilizando teorias da ciência política, sobre grupos de interesse e sobre funcionamento legislativo, debatendo a(s) hipótese(s). 


\section{Capítulo 1: Literatura e Método}

O trabalho tem como inspiração teórica debates que envolvem o papel dos grupos de interesse perante as decisões em torno das mais variadas políticas públicas. O caso do processo de modernização do futebol no Brasil, especificamente representado pelas relações de trabalho entre clubes e atletas, e pela administração das entidades desportivas, é interpretado aqui dentro do viés teórico da importância dos grupos de interesse nos processos políticos que dizem respeito a decisões sobre políticas públicas. O futebol passou a ser assunto, se não dos principais, pelo menos de grande importância (maior do que já teve em outras épocas), da agenda política nacional, sendo alvo de uma série de discussões na arena política - e também fora dela. Como qualquer outra política, muitos grupos de interesses ligados ao esporte, atentos a decisões que poderiam alterar seus destinos, acabaram adentrando ao universo político, procurando fazer prevalecer decisões que provocassem benefícios ou que barrassem prejuízos a eles. Em diversas ocasiões, de fato, como a pesquisa pretende mostrar, eles obtiveram sucesso e foram atores chave no resultado final.

Todavia, antes de abordar como o fizeram, é interessante situar o que se entende por grupo de interesse, quais são suas características principais e como atuam. Existe uma extensa literatura que trata do tema dos grupos de interesse na política. Não se pretende esmiuçar toda essa literatura neste trabalho, mas sim destacar a parte da mesma que é enxergada como um horizonte teórico da pesquisa e que se aproxima do que é entendido aqui como fator explicativo para o que se deu no âmbito empírico do tema estudado.

Em primeiro lugar, grupos de interesse serão definidos como conjuntos de indivíduos ou de organizações que compartilham características - como ideias, desejos e objetivos -, podendo contar com alguma organização formal ou não, e que tentam influenciar as decisões públicas, podendo atuar sobre o Estado tanto para mudar a situação presente quanto para preservá-la, se for o seu interesse (Baird, 2012).

Com diferentes objetivos, os grupos podem atuar com os diversos atores, como o poder legislativo, diretamente ou não com os deputados, assim como com o poder executivo, diretamente com a presidência ou com os ministérios, com as agências reguladoras (Baird, 2012), e com os partidos, por proximidade ideológica ou 
por financiamentos de campanhas, ou apenas relações próximas por meio de reuniões, físicas ou não (Rasmussen e Lindeboom, 2013). Por vezes, o próprio poder público convoca os grupos para debater as questões envolvidas, por meio de audiências ou ofícios enviados. Em outros momentos, as relações são menos claras, não aparecem em ambientes públicos e se dão em relações mais próximas entre poder público e representantes de grupos (Pedersen, 2013).

De qualquer maneira, os grupos de interesse procuram atuar diante das possibilidades de criação, manutenção ou mudança de determinadas políticas públicas. Estas, por sua vez, em geral, são compostas de diversas fases, ligadas entre si e os grupos podem atuar durante todas elas, bem como nas diferentes etapas do processo legislativo (Mancuso, 2004). Eles procuram influenciar funcionários de diferentes níveis de governo para alcançar seus objetivos, tentando fazer com que prevaleça suas crenças em relação às políticas públicas, sabendo que as regras das esferas de governo serão importantes para sua atuação, pensando suas estratégias as considerando, por exemplo, prevendo que os votos de parlamentares seguirão as orientações das lideranças partidárias (Mancuso, 2004).

À primeira vista, acompanhando, sem um estudo mais rigoroso, a atuação dos grupos nas diversas fases das políticas, é comum se ter a impressão de que tal atuação se dá apenas nos momentos de formulação das mesmas, como reação à política oferecida pelo governo. Uma vez adotada essa política, pode parecer que os grupos não atuam mais. Mas eles podem atuar tanto antes como depois da formulação, procurando influenciar a maneira como a política é planejada, e também quando tal política passa por alguns ajustes, como nas regulamentações de leis (Ripley, 1995).

Os grupos de interesse podem ir além de uma atuação que abrange apenas as movimentações de um grupo em si e formar coalizões de militância, que travam embates em torno das negociações em torno de uma política, cada uma defendendo aquilo que acredita ser o melhor para a política em questão. Eles fazem escolhas racionais em torno de seus interesses e formam coalizões para defendê-los (Olson, 1999).

Em geral, as coalizões são formadas por atores que compartilham visões muito próximas de alguma questão específica e atuam de maneira conjunta em defesa de 
suas visões (Sabatier e Jenkins Smith, 1999). Os embates se dão principalmente em processos de mudança de políticas públicas, o que exige que se adote uma perspectiva de tempo de uma década ou mais, como no caso do processo de modernização que ocorre no futebol brasileiro, a partir da década de 1980, o qual será analisado nesta pesquisa. É interessante, pensando nessa perspectiva de longo prazo, que se considere a intenção de um conjunto de atores individuais ou coletivos, de organizações públicas e privadas, de se preocuparem com uma questão específica de alguma política pública e de tentarem, regularmente, influenciar as decisões a respeito da questão.

As questões de política pública, nesse modelo de Sabatier e Jenkins Smith (1999), envolvem a participação não somente do legislativo, de agências do Executivo e grupos de interesse atuando em apenas um nível de governo. É importante também o papel da comunidade científica, como acadêmicos, analistas e consultores. Informações científicas podem ser uma boa base para dar legitimidade aos discursos das coalizões, criando novos paradigmas para determinados temas, que podem se tornar vigentes por um bom tempo. Os novos paradigmas podem estabelecer um novo sistema de valores, concretizados com a criação de elementos institucionais, como leis, decretos e políticas.

A formação dos novos paradigmas se dão como resultado daqueles embates entre duas ou mais coalizões que competiram, em uma arena política, pela hegemonia de um determinado pensamento e de valores em relação a uma política. Nesse sentido, a coalizão até então dominante seria representada pelo paradigma anterior e a coalizão desafiante traria uma nova perspectiva, que alteraria o status quo, formando um novo paradigma.

Para que se crie uma motivação para uma possível mudança de determinada realidade política, as coalizões utilizam discursos com conteúdos diferentes, que contam versões diferentes em relação a uma política, buscando alterar ou manter o status quo. Quanto mais adesões uma versão tiver, maior a chance da realidade ser alterada ou mantida. A partir daí, o discurso é transformado em interesses e ações concretas (McBeth, Shanahan, Arnell, Hathaway, 2007). Stone (2002) afirma que nas versões contadas, a linguagem e os símbolos inseridos na narrativa são utilizados estrategicamente, afim de reforçarem as ideias de cada um dentro dos embates. Uma 
versão tem boas chances de ser aceita caso conte com respaldo científico, o que não impede que uma narrativa tenha ampla divulgação sem a base científica. Nesse caso, o que definirá o resultado será a forma como a versão é contada.

Uma perspectiva prática dos resultados dos embates entre os grupos ou entre as coalizões de interesse, pode ser encontrada em Mancuso (2004), através da noção de "sucesso" e "insucesso", baseada na observação de convergência entre as demandas explícitas de um grupo de interesse (no caso do artigo, o setor industrial) e as decisões tomadas pelo poder público. Tanto os sucessos como os insucessos podem ser pontuais ou definitivos, bem como completos ou parciais.

Serão sucessos pontuais quando a decisão tomada em qualquer instância do processo legislativo de nível federal convergir com a posição apresentada pelo grupo, antes da deliberação final. Serão completos os sucessos pontuais nos casos em que o que foi decidido e a posição da indústria convergirem totalmente. Se não convergirem totalmente, os sucessos pontuais são parciais. Os sucessos pontuais ocorrem em decisões de comissões legislativas que não encerram a tramitação da matéria, em votações em plenário de uma Casa, seguida por alguma instância da outra Casa, e em votações em plenário das duas Casas, com caráter de encerramento de uma determinada questão, e que podem receber vetos da presidência. Os sucessos definitivos ocorrem nos casos em que a convergência entre determinado grupo e as decisões tomadas se dão numa decisão final de alguma matéria. São definitivos completos quando as duas posições são totalmente convergentes e definitivos parciais quando não forem totalmente convergentes.

Serão insucessos pontuais os casos em que houver divergência entre a decisão tomada e a posição do grupo, em decisões parciais, e insucessos definitivos quando houver divergência em decisões finais. Quando a divergência for total, os insucessos definitivos serão completos, e quando não for total, os insucessos definitivos serão parciais.

Algumas características institucionais podem indicar sucesso ou insucesso em uma determinada questão, por exemplo em uma transformação de um projeto em norma jurídica, ou quando alguma matéria for rejeitada, prejudicada, retirada pelo autor ou arquivada ao final da legislatura. Será sucesso ou insucesso dependendo da posição adotada pelos grupos. O resultado, argumenta Mancuso (2004), tende a ser influenciado pela convergência de agendas entre um grupo e o poder executivo que, 
no sistema político brasileiro, detém prerrogativas importantes, como poder de veto, possibilidade de propor matérias em caráter de urgência e proposição do orçamento (Limongi e Figueiredo, 1998). É importante, portanto, para os grupos, tentar fazer com que as preferências do Executivo coincidam com as suas. Se as preferências convergirem, os grupos atuarão juntos a tal poder. Caso contrário, os grupos lutarão para que os objetivos se aproximem, o que significa dizer que o considerável poder que o Executivo detém pode muito bem ser compatível com a atuação dos grupos de interesse organizados, mesmo a condicionando, e abrir espaço para que estes tentem dividir a participação nos resultados de uma determinada questão.

A ideia é que essas referências teóricas funcionem como uma inspiração teórica para tentar entender o que se deu na atuação dos grupos de interesse a partir do processo de modernização do futebol no Brasil, por vezes argumentando que a explicação do caso empírico e a teoria são quase que perfeitamente encaixadas, e por outras, que a teoria serve como uma referência de explicação, mas que o caso empírico não se deu exatamente daquela forma. De qualquer maneira, esses temas da bibliografia serão utilizados aqui, desde a definição do que são os grupos, até como atuam, as coalizões formadas e os resultados da atuação deles. Em resumo, a ideia é, a partir das referências, estudar um processo de mudança de uma determinada política, no caso a relativa ao futebol, e como os grupos de interesse e as coalizões de interesse atuam nesse processo e quais grupos ou coalizões tiveram sucesso ou insucesso e por quê.

A pesquisa realizada foi de natureza predominantemente qualitativa, tratandose de um estudo de caso. As principais fontes de análise foram dados oficiais referentes à tramitação da Lei Zico, da Lei Pelé e das leis, decretos e regulamentos subsequentes, uma busca no acervo digital dos jornais Folha de São Paulo e Estado de São Paulo, bem como notícias de outros veículos de mídia - em geral e esportivos, como o jornal "O Lance!" e a revista "Placar" -, a leitura de artigos e livros referentes às leis, e ao esporte, em geral, encontrados em arquivos tais como Scielo, Dedalus e Ludopédio, e, por fim, uma entrevista com o relator do projeto da Lei Pelé na Câmara dos Deputados.

A tramitação dos projetos foi analisada, através dos dados disponíveis pelo site da Câmara dos Deputados, do Senado e da Presidência da República, com os arquivos disponibilizados por esses endereços eletrônicos, como publicações nos 
Diários Oficiais, que apresentavam discussões nas comissões e outras arenas, que foram palco das análises dos projetos de lei.

Para que fossem obtidas informações adicionais, foi feita uma pesquisa no acervo digital dos jornais Folha de São Paulo e Estado de São Paulo, buscando pelas palavras-chave "Lei Pelé", "Eurico Miranda"(ator importante, na época deputado federal e vice-presidente do Clube de Regatas Vasco da Gama), "dívidas clubes futebol", "lobby clubes futebol", "Zico", "Lei Maguito Vilela", "Estatuto do Desporto" e "Timemania". Todas as notícias encontradas que faziam referência ao debate sobre os temas aqui estudados, envolvendo atores políticos e grupos de interesse serviram como informação e foram organizadas num arquivo, que foi analisado e foi base para captar as movimentações realizadas pelos diferentes grupos de interesse e pelos atores políticos, o que foi comparado ao que se passou na tramitação do projeto e com informações trazidas pela bibliografia lida.

Artigos e livros sobre legislação esportiva, sobre esportes, sobre importância econômica do futebol, sobre relações de trabalho no futebol, sobre gestão no futebol e sobre grupos de interesse e relações entre estes e o poder político, foram outras fontes de grande importância, encontradas em acervos como o do Scielo, Dedalus, Ludopedio e Ludens, que trouxeram informações sobre os dispositivos legais, sobre questões técnicas e também sobre dados relativos aos assuntos, por exemplo, números e informações sobre a administração dos clubes de futebol.

Por fim, foi utilizada uma entrevista realizada com o relator do projeto da lei Pelé na Câmara dos Deputados, Antônio Geraldo (então PFL-PE), com perguntas de caráter discursivo, em profundidade.

Tanto os dados obtidos na leitura das notícias de jornais e revistas, como aqueles encontrados nos documentos oficiais, como tramitação de leis e relatórios, serviram de base para a utilização da ferramenta metodológica da análise de narrativa política. Trata-se de uma ferramenta interessante para uma pesquisa que se propõe a reconstituir debates que se deram em torno de uma determinada questão ou política pública, ao longo de um período abrangente, como o da presente pesquisa, que aborda o debate sobre a modernização do futebol, desde o final da década de 1980 até o ano de 2014. 
Autores como Jones e McBeth (2010), McBeth, Shanahan, Arnell, Hathaway (2007), Stone (2002) e Roe (1994), de maneira geral, apontam que a narrativa política tem uma estrutura, que envolve o contex to em que uma política está sendo debatida, o enredo ou desenrolar dos debates, as personagens envolvidas e as soluções políticas dadas. Nesse processo, os atores tentam direcionar seus discursos a um resultado político de sua preferência (Jones e McBeth, 2010).

A análise da narrativa política se encaixa no estudo das mudanças políticas, que envolvem os embates das diferentes coalizões de defesa (Sabatier e Jenkins-Smith (1999), pois as narrativas podem ser documentadas durante um longo período de tempo e elas apresentam crenças políticas fundamentais, diante das quais os diferentes atores interessados nas questões disputarão para que suas crenças prevaleçam (McBeth, Shanahan, Arnell, Hathaway, 2007). O discurso que se torna vencedor acaba impulsionando a mudança política, institucionalizando a política preferida pelos vencedores (Hajer, 1993). As narrativas podem, ainda, influenciar na aprendizagem política, embasadas ou não na informação científica possível (Shanahan, Jones, McBeth, 2011).

Tal ferramenta permite que se identifiquem as diferentes ideias e estratégias utilizadas pelos atores na tentativa de fazer prevalecer seus objetivos nos resultados finais de um processo decisório que resulta em alguma mudança de paradigma de determinada questão ou política. Os discursos em si podem ser indicativos do que as coalizões diretamente pensavam nos momentos específicos, como também podem ser estratégias para que conseguissem chegar a determinados objetivos (McBeth, Shanahan, \& Jones, 2005), mesmo que aquilo que estivesse no conteúdo dos discursos não fosse o que realmente os atores desejavam, mas sim apenas uma ferramenta para alcançar algum outro objetivo (Stone, 2002). Aqui, a intenção é não tanto tentar desvendar interesses escondidos nas palavras dos representantes dos grupos, mas mais aquilo que pronunciaram publicamente, tanto nas arenas decisórias como fora delas.

É importante deixar claro que, tanto a utilização da análise dos discursos, como qualquer outra alternativa metodológica, tem limitações, principalmente no que diz respeito à reconstituição de processos complexos, como muitas decisões políticas. Como argumenta Mancuso (2004), é muito difícil que se possa mostrar toda e qualquer ação de algum grupo ou indivíduo que comprove de maneira definitiva que 
um resultado se deveu a tal ação. Sempre podem existir outras explicações para o que fez com que se desse aquele resultado, como as convicções pessoais dos tomadores de decisão, ou a pressão de outras personagens, como os seus eleitores e a opinião pública em geral. Por vezes, nem mesmo os próprios tomadores de decisão conseguem dizer com precisão que fator foi definitivo para sua posição final. A dissertação tem consciência disso e tentou reconstituir o debate das questões sobre a modernização no futebol brasileiro considerando que vários elementos podem acabar escapando da análise. No entanto, procurou-se aproveitar ao máximo aquilo que esteve ao alcance com os métodos e fontes escolhidos. 


\section{Capítulo 2: Histórico do futebol no Brasil}

O futebol surge no país, no final do século XIX, como atividade amadora, caracterizado por pagamentos de salários ainda muito baixos, quando existia tal pagamento. Na maior parte dos casos, eram pagas gratificações não exatamente na forma de um salário, mas certa quantia por participar dos jogos. As receitas dos clubes eram, exclusivamente, vindas da bilheteria dos jogos e pouco existia de relações comerciais (Aidar e Faulin, 2006). A necessidade de profissionalização começava a ser discutida desde meados da década de 1930, quando passavam a se desenvolver, entre jogadores e seus empregadores, relações que eram próprias do universo do trabalho (Gonçalves e Carvalho, 2006). Ainda assim, o período foi marcado por princípios como associacionismo, finalidade não lucrativa, dirigentes não pagos e clubes, federações e confederações livres da intervenção do Estado (Manhães, 1986).

A partir do final da década de 1930, e começo da de 1940, começa a se estabelecer uma interferência do governo, por conta do crescimento da profissionalização, que gerava conflitos de competência entre as diferentes federações que desejavam administrar o futebol, a saber, a Confederação Brasileira de Desportos (CBD) - mais antiga e defensora do amadorismo -, e uma confederação de futebol, mais nova, que buscava a ampla profissionalização dos jogadores (Manhães, 1986). O decreto-lei 3199, de 1941, é assinado durante o governo Vargas e cria o Conselho Nacional de Desportos (CND), órgão que controlaria praticamente todas as atividades relacionadas ao esporte no país, presidido pelo jurista João Lyra Filho.

Tratava-se de um órgão burocrático, vinculado ao Ministério da Educação e Saúde, que objetivava incentivar o amadorismo e monitorar o profissionalismo. Como destacado anteriormente, o órgão foi criado com o objetivo de colocar ordem nas disputas entre as confederações citadas anteriormente, que queriam assumir a administração do futebol perante o crescimento do profissionalismo. O CND passa a centralizar todas as atividades, mediando os mais diversos conflitos (Manhães, 1986).

As competências do CND são reguladas por dois decretos, 5342/43 e 7674/45, mas apenas para manter a preponderância do órgão, deixando, pelo primeiro deles, os registros dos contratos a cargo do $\mathrm{CND}$, e, pelo segundo, o controle das 
movimentações financeiras das entidades, por meio da indicação dos livros necessários para o registro delas (Manhães, 1986), também nas mãos do órgão. Além disso, proibia o emprego de capitais para geração de lucro (Melho Filho, 1995).

Até a década de 1950, as entradas para os jogos ainda eram a principal fonte de receita para os clubes - e continuam sendo até a década de 1980 - e começa a aumentar a ligação entre torcedor e clube (Marques, 2005). A partir dos anos 1960, o profissionalismo vai tomando forma, mas, ainda assim, os salários continuam baixos e as relações entre clubes e atletas, informais.

Na década de 1970, o poder do CND é ampliado com a lei 6251/75, tornandose o órgão legislativo, executivo e judiciário do esporte. As interferências do governo militar se mostravam claras, como em dois exemplos. Primeiramente, nas relações estabelecidas entre o então presidente da República, Costa e Silva, e o presidente da Confederação Brasileira de Desportos, João Havelange, no sentido de aumentar o poder financeiro e de influência deste último e, ao mesmo tempo, o prestígio do Governo Federal, através de sucessos da seleção brasileira de futebol (Chaim, 2014). Posteriormente, no afastamento de Havelange, realizado pelo então presidente da República, Ernesto Geisel, que fez a troca pelo almirante Heleno Nunes, membro do Diretório Nacional da ARENA, partido do governo (Alves e Pieranti, 2007).

Ainda na década de 70, a interferência estatal demonstra sua força, na questão da relação entre atleta e clube, que passa a ser regulada pela lei n. 6354/76, assinada por Ernesto Geisel, e estabelece o mecanismo do passe, depois de muitos debates, vindos desde 1971, dentro do universo esportivo e da sociedade civil, sobre a profissionalização dos jogadores de futebol e sua possível equiparação ao trabalhador comum (Correia, 2010).

Aqui, é preciso fazer parênteses para o passe ser conceituado, já que ele será importante na pesquisa, pois a sua extinção, que virá com a Lei Pelé, provocará mudanças relevantes nas relações de trabalho entre atletas e clubes. A definição oficial do mecanismo do passe pode ser encontrada na lei 6354/76, Art. 11: “Entendese por passe a importância devida por um empregador a outro, pela cessão do atleta durante a vigência do contrato ou depois de seu término, observadas as normas 
desportivas pertinentes". ${ }^{2}$

O passe era um mecanismo, presente no contrato dos jogadores com seus clubes, que garantia a estes que, caso um jogador quisesse quebrar o contrato, seja para atuar em outro clube, seja para simplesmente não jogar mais pelo primeiro clube, este seria ressarcido por tal quebra, recebendo uma quantia em dinheiro. É diferente do que existe hoje, a multa rescisória, porque atualmente a quebra do contrato em vigência prevê um valor a ser pago por quem quer que rompa o contrato. Tanto clube como jogador - ou outro clube, interessado em contar com o jogador -, devem pagar tal valor. No caso do passe, se o clube rompesse o contrato, não tinha a obrigação de pagar nenhuma indenização, apenas o jogador, caso quisesse sair. Outra diferença é que, hoje, se o contrato chegar ao fim, o jogador pode assinar contrato com outro clube, sem precisar pagar nada ao clube com o qual tem vínculo. Quando existia o passe, mesmo que o contrato chegasse ao fim, a indenização ao clube ainda deveria ser paga. Por fim, o jogador só poderia ter passe livre, ou seja, ser dono do seu passe, a partir dos 32 anos de idade. Hoje, o jogador pode se tornar profissional a partir dos 16 anos, e não tem idade para ser dono de seus direitos. O que existe é um período mínimo para o tamanho do contrato e um máximo para o término (6 meses e 5 anos, respectivamente).

A lei 6.354 abarcava diversos elementos referentes à profissão de jogador de futebol, incluindo o passe. Todas as questões envolvendo o contrato de trabalho dos atletas e suas obrigações com os clubes empregadores eram reguladas por essa lei, como transferências e empréstimos para outros clubes, as penalidades por descumprimento de contrato, além de questões técnicas da profissão, como período para preparação física. A prática do futebol profissional passa a ser regulamentada através do decreto 80.228/77 (Boudens, 2000).

A regulamentação do profissionalismo abriu algumas oportunidades para organização da categoria dos atletas de futebol. Em 1977, é formada a Associação Profissional de Atletas de Futebol, com o jogador do Vasco da Gama, Zé Mário, como liderança, auxiliado por Zico. Além desta associação, também aparecem a Associação de Garantia ao Atleta Profissional (AGAP) e o Fundo de Garantia de Amparo ao Atleta (FUGAP), os quais, juntamente com a primeira associação, ainda

${ }^{2}$ Lei 6354, de 2 de setembro de 1976. Dispõe sobre as relações de trabalho do atleta profissional de futebol e dá outras providências. 
que de forma tímida, apenas por meio de auxílio aos atletas, procuravam lutar pelos direitos dos mesmos (Correia, 2010). Em 1979, é formado o Sindicato dos Atletas de Futebol do Estado do Rio de Janeiro, também liderado por Zé Mário, que se relacionava bem com alguns dirigentes e procurou representar os direitos dos jogadores em muitas oportunidades, em negociações com tais dirigentes (Correia, 2010). Esses foram, portanto, os primeiros movimentos de organização dos atletas de futebol, ainda pouco atuantes.

Os anos 1970 ainda viram um novo ator passar a fazer parte do cotidiano futebolístico, a televisão. De início, as transmissões dos jogos eram livres, e a TV pública era detentora dos direitos de transmissão. Inicialmente, nenhum valor era pago aos clubes; posteriormente, começou-se a pagar valores muito baixos. O período apresentava características, como a exposição de marcas em placas de publicidade nos estádios, que, posteriormente, resultariam no surgimento dos patrocinadores em larga escala, expandidos para as camisas dos clubes. (Aidar e Faulin, 2013; Marques, 2005).

Depois do crescimento da participação da televisão nos jogos de futebol, durante a década de 70, outro ator relevante entra no jogo, na década de 80 . Já que o futebol passa a gerar grande exposição, principalmente através das transmissões na televisão - já nas mãos da iniciativa privada -, os patrocinadores passam a ganhar força, e aumentam sua participação na geração de receitas dos clubes e também das ligas. Os direitos de transmissão dos jogos passam a envolver pagamento de grandes valores (Marques, 2005). Ao mesmo tempo em que os recursos aumentavam, devido à participação da televisão e dos patrocínios, os salários dos jogadores também aumentavam e o aumento passa a se dar de maneira constante. A dinâmica mercadológica já está instalada e toma boa parte do ambiente do esporte. Os clubes começam a busca para vender suas marcas, procurando novas receitas e parcerias, visando ampliar mais ainda seus mercados, angariando mais torcedores, que, já se pode dizer, eram uma espécie de consumidores. (Haag, 2013).

Porém, a década de oitenta, no país, foi marcada por uma crise econômica e pela reestruturação política. Os efeitos atingiram os clubes, que entraram em uma situação financeira precária, recorrendo com frequência a endividamentos bancários e à negligência no recolhimento de impostos para a União. A saída, para a maioria deles, foi procurar obter receitas vendendo os passes dos seus melhores atletas, impulsionados pela dificuldade em pagar os salários - que aumentavam, assim como 
os valores dos passes - e em arcar com as crescentes exigências nos contratos. A venda dos passes dos atletas era uma considerável fonte de receita, visto que muitos clubes, se não contassem com essa verba, dependeriam somente das arrecadações de bilheteria - as quais nem sempre rendiam muito, pois já ocorria queda no público pagante dos jogos - e das contribuições de seus associados (Proni, 1998).

Nas décadas anteriores, desde os anos 1930, já aconteciam transferências de jogadores brasileiros para clubes estrangeiros. Mas tal cenário de complicações financeiras, causadas em grande parte pela crise econômica - e também pela má administração dos clubes, ainda muito caracterizada por atividades amadoras, contrastantes com o ambiente profissional e de negócios que se desenvolvia -, fez com que o volume de negociações, na década de 80 , fosse muito maior, com os clubes estrangeiros pagando valores cada vez maiores, e tendo facilidade em contratar os atletas brasileiros, dada a desvalorização da moeda nacional na época (o cruzeiro) (Proni, 1998).

Já no final da década de oitenta, o ímpeto por interesses comerciais se intensifica, o CND passa a não ter mais influência nos destinos das federações e clubes, e o Clube dos 13 é criado para organizar o campeonato nacional, em 1987, depois de a Confederação Brasileira de Futebol (CBF) alegar não ter condições de dar conta do campeonato brasileiro naquele ano. A televisão aparece como a fonte de receita mais importante (Aidar e Faulin, 2013). A década de 80 acaba e a de 90 se inicia, portanto, com o crescimento vertiginoso dos interesses comerciais, a valorização dos passes dos jogadores, juntamente com seus salários, o que colocava o futebol no mundo dos negócios, não compatível com as práticas de organização de épocas anteriores, ainda presentes. O momento atraía incentivos para uma reestruturação legal e institucional, até mesmo para criar um ambiente jurídico novo, que permitisse a adaptação dos clubes à nova lógica que adentrava no cenário futebolístico, amplamente influenciado pelo contexto neoliberal que passava a penetrar nos mais diversos setores da economia brasileira (Proni, 1998). Os contratos de parceria entre clubes e empresas se tornavam cada vez mais comuns, não só nas alianças destinadas a patrocínios (Gonçalves e Carvalho, 2006), mas também nas gestões comerciais dos clubes, com o objetivo de dividir os lucros com as entidades, como no caso da parceria entre Palmeiras e a multinacional Parmalat - mesmo que boa parte não tenha durado até o fim dos contratos (Leoncini e Silva, 2005).

Apesar de, em comparação às grandes empresas e a outros esportes, como o 
futebol americano, possuir representatividade financeira muito menor do que comumente é considerado (Gaspareto, 2013), o futebol se transformou, e é até hoje, de acordo com o relatório final do Plano de Modernização do Futebol Brasileiro (2000) da Fundação Getúlio Vargas (FGV) (Leoncini e Silva, 2005), um negócio que envolve a circulação de bilhões de dólares em todo o planeta e gera disputas para administrar as entidades que regem a modalidade, em busca do controle de um negócio cujos valores vêm se multiplicando (Proni, 1998). Trata-se de um produto de grande valor para o sistema capitalista, já que, como muito se argumenta, o futebol se trata de uma paixão, para a qual o torcedor não vê substitutos (Aidar e Faulin, 2013). Os próprios casos de corrupção, recentemente descobertos por ação do FBI e da polícia suíça, exemplificam o poder econômico que esse esporte desenvolveu e que, cada vez mais, ele pode ser um assunto relevante a ser estudado.

O caminho para a profissionalização da gestão se abre e, no discurso de pessoas de negócio, de agentes públicos, de alguns parlamentares, de alguns dirigentes de clubes e de boa parte dos meios de comunicação, torna-se uma necessidade que o futebol seja tratado como negócio e os clubes sejam geridos como empresas.

Porém, muitos deles acabaram resistindo a fazer a transição para uma gestão profissional, mantendo certos laços sociais e comunitários, muito comuns nas administrações em décadas passadas. As práticas dessas décadas não foram deixadas de lado e passaram a conviver com as práticas voltadas aos negócios. Os dirigentes queriam as duas coisas. Por outro lado, o Estado, que antes pouco se posicionava e mantinha leis que abrigavam mecanismos não condizentes com o profissionalismo, como o passe, passa a ser agente regulador e legitimador da mudança institucional. A própria Constituição de 1988 já havia incluído o esporte como assunto de interesse estatal e com objetivos sociais ${ }^{3}$. Ao mesmo tempo, são incentivadas as práticas de mercado e da gestão empresarial (Gonçalves e Carvalho, 2006), até porque uma parte dos clubes, sozinhos, como se viu, não estava totalmente empenhada em passar por transformações, e ainda convivia com os problemas que apareceram nos anos oitenta.

Esse, portanto, é um período que de grande movimentação no sentido de transformar o futebol numa atividade econômica, de marketing, etc, e será tema no próximo capítulo, que explicita o processo de "modernização" do futebol brasileiro.

\footnotetext{
${ }^{3}$ Constituição da Republica Federativa do Brasil, Capítulo III, Seção III, Art. 217.
} 


\section{1) Modernização do futebol brasileiro}

O futebol brasileiro passou por um desenvolvimento histórico que culminou com sua popularização e, em determinado momento, com a atração do interesse da televisão e de patrocinadores. A década de 1980 foi um momento de muita intensidade desse processo. O dinheiro e as marcas passam a fazer parte do dia a dia do futebol no país. Ocorre uma mudança na forma de organizar e administrar o esporte. O Estado deixa de exercer a influência dos tempos de CND, tanto com Vargas como com os militares. Os destinos começam a ser definidos pela televisão, pelos patrocinadores, investidores, juntamente com os dirigentes dos clubes, das federações e da CBF (Mezzadri et al., 2011).

O que é entendido nesta dissertação como o processo de "modernização" do futebol brasileiro é o caminho histórico de tal esporte, que parte de uma atividade amadora, ligada aos clubes e seus associados, profissionaliza-se, recebe intervenção estatal por um longo período e, por fim, passa a responder de maneira positiva, por grande parte de seus atores, aos incentivos do mundo financeiro e do marketing, cada vez mais se tornando um negócio.

Está relacionado ao que Martins (2012) entende por "modernização" do futebol, a saber, a alta integração e incorporação do esporte à valorização do capital, diferente do conceito de modernização trabalhado por Florenzano (1998), que trata das mudanças ocorridas dentro do jogo em si - que se torna mais voltado à força física em países europeus na década de 1960 -, não de suas relações com a sociedade e o mercado.

O futebol entendido como negócio passa a ser o foco. Essa adequação ao mundo da valorização do capital é representada pelo aumentos nos investimentos na modalidade, através dos patrocínios de camisa e de campo de jogo, pelas transmissões pela televisão de partidas, representando investimento das emissoras, pelo mercado futebolístico nacional criado, e pela valorização dos jogadores famosos e suas transferências para o exterior, formando um mercado de jogadores (Martins, 2012). O processo, no mundo futebolístico, é visto como no mundo social e econômico. A intenção é se basear no que é visto nos países mais influentes ${ }^{4}$ e buscar

\footnotetext{
${ }^{4} \mathrm{O}$ primeiro exemplo, que influenciou inclusive outras ligas de clubes de países da Europa, foi o da liga italiana, que, na década de 1980, aprovou uma legislação liberal, permitindo os clubes de futebol se transformarem em empresas. A partir daí, começou a se tornar prática recorrente a exposição de marcas nas camisas dos clubes (Proni, 1998). Não demorou e a
} 
transformações voltadas para os interesses destes países, como a exportação de jogadores.

O paradigma do futebol como negócio passa a ser adotado como o novo grande discurso da área. Há muita resistência por parte de diversos setores, como dirigentes de clubes e federações, que eram acostumados ao estilo amador de administrar os clubes e os campeonatos. O que não significa dizer que todos os dirigentes se voltaram contra tal discurso. Administrar o clube à maneira de uma empresa interessava a alguns dirigentes (Martins, 2012).

O exemplo estudado no trabalho de Martins (2012), o da chamada “democracia corintiana”, é um dos primeiros a adotar a mentalidade "moderna". O Sport Club Corinthians Paulista passava por um momento conturbado, tanto dentro como fora de campo, e a modernização era vista como a saída para superar a crise. O clube já possuía grande torcida e sua direção queria aproveitar o potencial mercadológico que o nome do time trazia, especializando a gestão nos departamentos de futebol, organizando-os financeiramente, trazendo rentabilidade e viabilidade nos negócios (Martins, 2012).

O dirigente Waldemar Pires trazia novidades gerenciais, como a organização de um conselho de orientação, que contava com empresários de diversas áreas, como psiquiatria, representada por Flávio Gikovate; publicidade, com o nome de prestígio de Washington Olivetto, quem, inclusive, cunhou o termo "democracia corintiana"; e jornalismo, com José Roberto de Aquino.

Outro ponto era o pagamento de salários generosos, especialmente para jogadores considerados "estrelas", os quais a direção do clube acreditava que seriam fundamentais para a rentabilidade do mesmo. Foram feitos contratos publicitários que ajudavam a pagar estes salários e também estampavam a camisa com suas marcas, casos de Bradesco (contrato de publicidade de Cr\$200 milhões, o primeiro com esses valores no Brasil), e da Bombril, que representou Cr\$10 milhões ao clube, por um jogo, a final de um campeonato paulista (Martins, 2012).

Esse efeito dos patrocínios teve o auxílio da televisão, que, ao transmitir os

influência chegou ao Brasil. Além disso, a própria FIFA, a partir de 1974, com a entrada de João Havelange na presidência da entidade máxima do futebol, começava a implantar um projeto de expansão do futebol pelo mundo, realizando estratégias empresariais e de marketing, por meio de parcerias com a fornecedora de material esportivo Adidas e com a empresa Coca-Cola (Proni, 2000). E a própria escolha dos Estados Unidos como sede da Copa do Mundo de 1994 demonstrou um interesse em ampliar os horizontes do mercado do futebol (Reis, 2003). 
jogos ao vivo, gerava uma ótima oportunidade para as marcas serem exibidas, além dos próprios atletas. Também contribuiu para o tratamento do torcedor como consumidor, com ideiais de oferecer um bom "espetáculo" para quem assiste, atraindo ainda mais patrocinadores e investidores.

A nova administração procurava, ainda, implementar uma nova maneira de se relacionar com os atletas, buscando ter o mínimo possível de conflitos, e dando liberdade para os jogadores se posicionarem e tomarem decisões que dizia respeito a eles. No entanto, não conseguiu modernizar por completo tal esfera, pois a relação de trabalho ainda não era marcada pela liberdade nos contratos de trabalho (Martins, 2012), ou seja, o mecanismo do passe ainda vigorava.

Tal gestão foi pioneira no futebol brasileiro, mesmo que ainda não tivessem provocado alguma reação que significasse alterações na legislação e na estrutura esportiva. Mas, certamente, contribuiu para que se começasse a discutir tais mudanças. Além disso, influenciou o Clube de Regatas Flamengo a tentar uma direção progressista (Martins, 2012), com a presidência de Márcio Braga, também, à época, deputado federal, atuante não só no Flamengo como no Congresso, na causa da modernização do futebol brasileiro.

Outros, ao longo do tempo, aderiram e colocaram seus clubes dentro do processo de modernização, firmando parcerias com empresas, que, em alguns casos, resultaram em sucesso, como a parceria Palmeiras-Parmalat, as relações, em determinados momentos, entre Corinthians e Excel; Cruzeiro e Corinthians, e Hicks Muse; Vasco da Gama e Nations Bank, que acabaram, alguns deles, trazendo resultados positivos dentro de campo. De qualquer maneira, houve resistência e também houve compra do discurso e ainda hoje é assim, porém com mais dirigentes aderindo ao discurso e procurando, na linguagem que eles e muitos veículos da imprensa utilizam, modernizar a gerência dos clubes.

A própria imprensa tem papel relevante nesse processo. A cobertura de fatos ligados a elementos do futebol ligado ao mundo das empresas, dos negócios e do marketing, em grande parte dos veículos, foi, e ainda é, feita com bons olhos. As notícias e os textos de opinião, em sua maioria, se referem a tais mudanças como coisas que terão efeitos absolutamente positivos para os clubes e para o futebol brasileiro, de forma geral. Assim como grande parte das críticas a dirigentes se dá no sentido de contestar ações de resistência à adoção do modelo empresarial e de profissionalismo. 
O processo de modernização culmina com o que o futebol é hoje no Brasil, com papel de exportador de jogadores para países da Europa, para o Japão e, mais recentemente, para países do Oriente Médio, do Leste Europeu, para a China e para os Estados Unidos. Também cumpre o papel de país que foi sede da última Copa do Mundo, que, aliada ao já existente movimento de transformação do cenário futebolístico, potencializou grandes mudanças nos estádios pelo país, transformados em arenas modernas, ao estilo das grandes europeias, com cadeiras ao longo de praticamente todo o estádio, estruturas atualizadas, conforto ao torcedor, oferecimento de serviços não comuns ao típico torcedor de arquibancada e políticas de preços elevados de ingressos para os jogos.

Por fim, e não menos importante, chega-se também ao acirramento da profissionalização dos jogadores e incentivos cada vez maiores para a administração dos clubes ser voltada para características empresariais, o que não significa estritamente transformar os clubes em empresas, mesmo que alguns tenham passado por tal processo em alguns momentos, mas uma gestão voltada para o mercado, racionalizando decisões, especializando departamentos e criando estruturas burocráticas parecidas com as de empresas (Martins, 2012).

Nesse cenário se inserem os dois elementos estudados na pesquisa, que têm importância fundamental para o processo de mudança citado. As relações de trabalho entre clubes e atletas se tornam cada vez mais profissionalizadas, por meio do fim do passe - ainda que se tenha passado por um período de convivência entre as formas mais profissionais de relações entre eles e a existência do passe, extinto após a regulamentação da lei Pelé (Martins, 2012). Por outro lado, a administração dos clubes, por maior resistência que possa ter ocorrido e continue ocorrendo, segue num movimento de profissionalização voltado ao pertencimento ao mundo dos negócios. A especialização, a profissionalização e a produtividade se tornam elementos cruciais, voltados para o mundo financeiro (Mezzadri et al., 2011).

Toda essa discussão se dá no mundo do futebol, mas é inserida, durante todos esses anos de processo, no meio da política. Muitas questões entram em debates no Congresso Nacional, algumas passam pelo Executivo e medidas partem de tais poderes. Já em 1983, o então deputado federal e dirigente do Clube de Regatas Flamengo, Márcio Braga, pediu e a Câmara dos Deputados realizou um ciclo de 
debates sobre o futebol brasileiro, do qual participaram dirigentes da $\mathrm{CBF}$, das federações, de clubes, jornalistas e o então jogador do Corinthians, Sócrates. Estes últimos e alguns dirigentes, como os da democracia corintiana, apontavam para um cenário de desorganização, amadorismo e divisão de poderes desigual entre federações e clubes, com o instituto do voto unitário para eleições da CBF, o que dava peso igual para os clubes grandes e para os pequenos, o que, segundo aqueles atores citados anteriormente, prejudicava os grandes e o futebol nacional, em favor dos campeonatos locais, que não trariam receitas significantes para os grandes (Martins, 2012). Outras discussões no âmbito político se deram ao longo do tempo e serão discutidas mais à frente, inclusive passando pelo ímpeto de se transformar o status jurídico dos clubes, a fim de adequá-los à maneira empresarial.

O universo político, por conseguinte, não discutiu todos esses temas de forma isolada, sem receber as opiniões e a influência dos atores envolvidos nas discussões, que podem gerar mudanças significativas para eles. É nesse ambiente que os grupos de interesse tentam influenciar as possíveis decisões do poder público, que podem ter efeitos positivos ou negativos para eles.

A pesquisa buscará, por fim, entender como a política influenciou esse processo de modernização do futebol no Brasil, e, principalmente, qual foi o papel dos grupos de interesse nas decisões que os parlamentares e o poder executivo tomaram ou deixaram de tomar, com respeito a aspectos de tal processo. 


\section{Capítulo 3: Modernização do futebol no processo político}

A partir daqui, é necessário mostrar como o processo de modernização, descrito no capítulo anteriores, se deu dentro do ambiente político brasileiro. Como ele, especificamente pelos dois temas que o representam - relações de trabalho e administração dos clubes -, passou pelos diferentes âmbitos do poder e, especialmente, como os grupos de interesse atuaram dentro desse contexto, mantendo o status quo ou alterando-o, procurando influenciar as decisões do poder público, nos momentos decisivos dessas áreas dentro do processo político.

O capítulo irá apresentar o desenrolar dos eventos referentes a dois períodos distintos da trajetória recente do futebol no Brasil: um primeiro período, chamado aqui de liberal, que vai do governo de Fernando Collor de Mello (PRN) até o segundo mandato de Fernando Henrique Cardoso (PSDB), e que abrange momentos decisivos na liberalização do futebol brasileiro, como as discussões sobre o fim do passe e a formação dos clubes-empresas, trazidas à tona durante a tramitação da Lei Zico, da Lei Pelé e suas alterações, da Lei Maguito Vilela e das CPIs do futebol, na Câmara e no Senado; e o segundo período, aqui denominado regulatório, que abarca os dois governos de Luiz Inácio Lula da Silva (PT) e o primeiro mandato de Dilma Rousseff (PT), caracterizado por medidas mais diretas de ação governamental nas políticas esportivas, como a criação de um estatuto que daria as diretrizes da política de esportes do país (Estatuto do Desporto), a negociação de dívidas das entidades esportivas com o governo, a criação da Timemania e o debate sobre uma Lei de Responsabilidade Fiscal do Esporte, ainda em discussão no legislativo.

Os capítulos anteriores mostraram como o futebol brasileiro começou a entrar no processo de modernização, embalado pelo contexto internacional, em que as maiores forças do futebol vinham se modernizando há algum tempo. Como foi visto, o mundo do futebol passou a ser envolvido pelo mundo econômico e do marketing, que trouxe para o esporte a mentalidade empresarial, que se intensifica com o passar dos acontecimentos. Foi criado o Clube dos 13 e a Constituição de 1988 inseriu o esporte em seu conteúdo, como preocupação estatal, voltada para o caráter social.

A redemocratização da política brasileira também inclui o esporte, de maneira 
geral, e o futebol, especificamente, na liberalização, depois de muitos anos de regime militar autoritário, com a proposição, nos anos seguintes, de medidas que alterariam a lei da década de 70, trazendo maior liberdade na relação trabalhista para os atletas. Depois do ciclo de debates proposto pelo então deputado federal e dirigente do Flamengo, Márcio Braga, e realizado na Câmara dos Deputados, em 1983, citado no capítulo anterior, a primeira tentativa de liberalização se dá durante o governo Collor (1990-1992), em que é criada uma Secretaria de Esportes, que teve como responsável o ex-jogador Zico ${ }^{5}$ (Artur Antunes Coimbra), simbolicamente um nome expressivo nessa nova fase, pois foi um jogador muito admirado e visto como alguém que possuía uma visão crítica e moderna sobre o futebol, tendo, inclusive, feito críticas à CBF em 1989, afirmando que a Copa do Brasil se tratava de um torneio "caçaníqueis" ". Inicia-se uma discussão em torno de medidas que mudariam a realidade do esporte no Brasil, especialmente as relações de trabalho entre clubes e atletas.

\section{1) Período Liberal}

O que se deu nesse período foi uma tentativa de inserir o esporte numa lógica de transformações liberais pelas quais o Brasil passou após a redemocratização, com os governos de Collor, Itamar Franco e Fernando Henrique Cardoso. Estes governos procuraram implementar políticas de abertura de mercado no país, abrindo espaço para empresas multinacionais entrarem no mercado brasileiro, além de praticarem políticas de privatização de empresas estatais, em áreas como telefonia, energia, dentre outras.

O esporte não deixou de fazer parte desse plano de liberalização da economia por parte do governo. O que será abordado aqui é que o esporte, que já vinha, como visto, passando por transformações que o inseriam na lógica do mercado e do marketing, será alvo de esforços do governo e também do Congresso Nacional - não sem sofrer resistências de alguns setores -, para também ser efetivado como um esporte liberal, que seja amparado por leis e regulamentos que garantem a liberdade

\footnotetext{
${ }^{5}$ Zico foi o escolhido de Collor, após serem cogitados nomes como o de Carlos Alberto Torres e de Paulo Roberto Falcão. Carlos Alberto Torres será o novo secretário de Esportes, diz Bebeto. Folha de São Paulo, Especial II-Era Collor, 06 de março de 1990.

${ }^{6}$ Zico vai a Teresópolis para ver Collor jogar. Folha de São Paulo, Esportes, 9 de maio de 1990.
} 
de trabalho dos atletas, equiparando-os a trabalhadores comuns, e que procuram dar aos clubes uma estrutura empresarial, sob a justificativa de que tal medida resolveria o problema de uma suposta desorganização administrativa dos mesmos, que ocasionaria diversas perdas financeiras, dívidas com o governo, falta de pagamentos a jogadores e, consequentemente campeonatos deficitários e fracos tecnicamente.

\subsection{1) Lei Zico}

Nesta seção, será reconstituído o debate que se deu em torno do projeto de lei que resultou na chamada "lei Zico". As principais ideias iniciais eram a regulamentação das relações de trabalho entre clubes e jogadores, por meio da proposição de extinção do mecanismo do passe, e a adequação da gestão dos clubes à dinâmica profissional e mercadológica, por meio da proposta de opção de transformação dos clubes em empresas.

Quanto ao passe, a proposta era que fosse extinto de imediato, para os jogadores já profissionalizados, e, definitivamente em 1994, e os contratos de trabalho tivessem, no máximo, três anos de vigência. No entanto, depois de passar pela Comissão de Educação e Esportes da Câmara e pela votação em plenário da Câmara e do Senado, o fim do passe foi aprovado para ocorrer de maneira gradual. Os jogadores teriam passe livre a partir dos 28 anos de idade, conquistando $15 \%$ a partir dos 23 anos, com mais $15 \%$ a cada ano, e os $25 \%$ restantes aos 28 anos.

No caso das mudanças na administração dos clubes, por meio da transformação dos clubes em empresas, o modelo inicial previa as possibilidades dos clubes se transformarem totalmente em sociedades comerciais, constituir sociedades comerciais independentes para administrar os esportes ou contratar empresas para tal realização. A Comissão de Educação e Esportes da Câmara dos Deputados, o plenário da Câmara e do Senado aprovaram a possibilidade de os clubes escolherem se tornar empresas ou não.

As decisões sobre o projeto, como um todo, foram adiadas por diversos momentos. Zico queria a aprovação do projeto ainda em 1991. Não conseguiu e a apreciação ficou para 1992, passando pelas comissões e sendo levada para a votação em plenário, que ocorreu somente no início de 1993.

No início da década de 1990, passou-se a discutir a necessidade de uma nova 
legislação para o esporte, a fim de, principalmente, modernizar e democratizar as instituições esportivas, com algumas ideias ${ }^{7}$ como a do ex-presidente do Santos Futebol Clube e então candidato a deputado federal pelo PDS, em São Paulo, Miguel Assad, de separar o futebol profissional da parte social dos clubes, deixando o futebol sob responsabilidade da iniciativa privada. Por outro lado, também havia propostas de políticos ligados a clubes que iam na direção contrária ao discurso modernizante, como a de fortalecer os pequenos clubes e os campeonatos regionais, se diferenciando do que era feito em países europeus, considerados modelo. Era a proposta de Eurico Miranda, à época candidato a deputado federal pelo PL-RJ e vice-presidente do Vasco da Gama.

A principal proposta, no entanto, veio através do denominado "Projeto Zico", que, inicialmente, foi denominado "Lei de Normas Gerais do Desporto", que, a princípio, propunha acabar com o voto unitário nas federações esportivas. Cada entidade vinculada às federações possuía um voto, com peso igual nas eleições de seus representantes e na tomada de decisões. Zico acreditava que tal mecanismo favorecia os pequenos clubes, provocando um inchaço no número de clubes nos campeonatos, trazendo problemas técnicos e financeiros. Ele queria que os votos dependessem de critérios técnicos, baseados no desempenho dos clubes, o que consideraria como fator relevante, por exemplo, a conquista de títulos. O advogado especialista em legislação esportiva, Valed Perry, previa uma batalha jurídica em torno da questão ${ }^{8}$, pois as federações se apoiariam no artigo 217 da Constituição Federal, o qual tratava da autonomia das entidades esportivas em relação às suas organizações. Por outro lado, o secretário adjunto de Esportes, Antonio Simões da Costa, argumentava que autonomia não significava soberania nem independência frente às leis. Zico ainda iria propor o fim do Conselho Nacional de Desportos ${ }^{9}$, com o objetivo de deixar o fomento ao esporte para a Secretaria dos Desportos e a organização de campeonatos para as federações, tirando de vez o poder centralizador do CND, já amenizado na década de 1980, deixando o órgão apenas com poder consultivo.

\footnotetext{
7 "Esportistas" apresentam propostas vagas. Folha de São Paulo, Eleições, 25 de setembro de 1990.

${ }^{8}$ Zico já tem pronto projeto contra voto unitário. Folha de São Paulo, Esportes, 25 de agosto de 1990.

${ }^{9}$ Secretário Zico tem plano para acabar com CND. Folha de São Paulo, Esportes, 7 de setembro de 1990.
} 
O projeto foi elaborado e entregue ao presidente da república em 1990, inicialmente com previsão para tramitar no Congresso ainda neste ano, porém foi encaminhado para tal em 1991. O secretário dos esportes ${ }^{10}$, Zico, proporia uma série de mudanças no futebol nacional. Havia pressão da própria Fifa, por meio do então presidente João Havelange ${ }^{11}$, para que o futebol brasileiro se adaptasse ao que a entidade entendia por uma nova lógica financeira e técnica, o que significaria seguir o que os clubes europeus faziam. Várias das mudanças, na realidade, já vinham ocorrendo, conforme relatado no capítulo anterior, mas o governo, por meio da secretaria de esportes, pretendia regulamentar as novas tendências, inseridas numa lógica liberal. Os principais pontos do projeto de lei eram a regulamentação das relações de trabalho entre clubes e jogadores, por meio da proposição de extinção do mecanismo do passe, e a adequação da gestão dos clubes à dinâmica profissional e mercadológica, por meio da proposta de opção de transformação dos clubes em empresas.

Em respeito às relações de trabalho, a ideia original era que o passe fosse extinto, para os jogadores já profissionalizados, definitivamente em 1994 e os contratos de trabalho tivessem, no máximo, três anos de vigência. No caso dos jogadores que ainda iriam se profissionalizar, o projeto previa que os clubes teriam direito ao primeiro contrato, que teria duração de quatro anos. No caso das mudanças na administração dos clubes, por meio da transformação dos clubes em empresas, o modelo inicial previa as possibilidades dos clubes se transformarem totalmente em sociedades comerciais, constituir sociedades comerciais independentes para administrar os esportes ou contratar empresas para tal realização ${ }^{12}$. O projeto ainda vinculava a filiação a uma confederação à transformação em empresa ${ }^{13}$, dentro das possibilidades oferecidas, mas deixava livre a filiação a federações.

Essas alterações, no entanto, contrariavam muitos interesses de boa parte dos clubes e federações de futebol. A Confederação Brasileira de Futebol reagiu pouco

\footnotetext{
${ }^{10}$ De início, enfrentando falta de recursos para a respectiva secretaria: Secretaria de Zico não tem nem orçamento. Folha de São Paulo, Esportes, 8 de abril de 1990.

${ }^{11}$ Para a Fifa, Brasil tem que evoluir. Folha de São Paulo, Esportes, 24 de julho de 1990.

${ }^{12}$ Projeto de Zico põe fim ao passe e ao CND. Folha de São Paulo, Esportes, 31 de outubro de 1990.

${ }^{13}$ Já havia, inclusive, empresas interessadas em parcerias com clubes, aguardando a aprovação do projeto, como a Parmalat, que negociava com o Palmeiras e concorria com a Coca Cola. Coca-Cola atrapalha acordo Palmeiras/Parmalat. Folha de São Paulo, Esportes, 01 de março de 1992.
} 
tempo depois da apresentação da primeira proposta, após a realização de uma reunião da diretoria de entidade, com a participação de alguns presidentes de federações, como a de Eduardo Viana, do Rio de Janeiro, que considerou o projeto "um atentado contra a estrutura do futebol brasileiro". ${ }^{14} \mathrm{O}$ argumento utilizado foi justamente aquele previsto pelo advogado Valed Perry, sobre a constitucionalidade de medidas como a do fim do voto unitário das federações, baseando-se no artigo 217 da Constituição. O diretor jurídico da $\mathrm{CBF}$, Carlos Eugênio Lopes, alegava que a entidade tinha autonomia garantida pela lei máxima do país e somente seu estatuto poderia intervir em sua organização, por se tratar de uma associação civil. Havia, no entanto, dirigentes que apoiavam o projeto, como Marcio Braga, então candidato à presidência do Flamengo e deputado federal não reeleito, que considerava que o projeto mudaria a estrutura do futebol e, por isso, assustaria muita gente ${ }^{15}$. Alguns jogadores também se mostravam a favor, como Toninho, então zagueiro do Palmeiras e presidente do Sindicato dos Jogadores de São Paulo, que achava que os clubes deveriam apoiar o projeto $^{16}$.

Muitos dirigentes não queriam que retirassem uma das principais fontes de renda de seus clubes, que era o dinheiro vindo das vendas dos passes dos jogadores principalmente para clubes do exterior - e entendiam que a medida elevaria ainda mais os salários e as reivindicações dos atletas empregados. Além disso, argumentavam que a extinção do passe provocaria falência de muitos times pequenos, o que, consequentemente, causaria desemprego de muitos atletas e treinadores. No entanto, em reunião ${ }^{17} \mathrm{com}$ a União dos Grandes Clubes Brasileiros (também conhecida como "Clube dos 13"), o vice-presidente do CND, Álvaro Mello, garantiu aos clubes que a ideia era apenas tirar o poder intervencionista que a lei 6251/75 continha e que a questão do fim passe não acabaria com a receita vinda dos valores dos passes dos atletas, só flexibilizaria, sem prejudicar os clubes, uma lei que não dava liberdade aos atletas.

O projeto inicial foi discutido num seminário organizado pela secretaria de esportes e, neste evento, Zico adotava o discurso de que não faria alterações na

\footnotetext{
${ }^{14}$ Diretoria da CBF rejeita proposta de Zico para mudança no futebol. Folha de São, Paulo, 6 de novembro de 1990.

${ }^{15}$ Folha de São Paulo, Acontece/Esportes, Frases. 13 de novembro de 1990.

${ }^{16}$ Clubes agora querem conciliação com Zico. O Estado de São Paulo, Esportes, 16 de novembro de 1990.

${ }^{17}$ Ibid.
} 
proposta, que somente a CBF havia declarado oposição, especificamente em relação ao ponto da possível mudança nas eleições para presidência da entidade, e que os principais eixos do projeto não seriam alterados, como a transformação dos clubes em empresas e a extinção do passe, medidas que o secretário acreditava que fossem capazes de eliminar "pessoas que sempre se aproveitaram do esporte em benefício próprio, além de acabar com a escravidão imposta ao jogador brasileiro" ${ }^{18}$, sem especificar quais pessoas. No entanto, o próprio Zico admitia que sofria pressões fortes de "pessoas que tinham medo de perder o poder", sem novamente especificar quem seriam tais pessoas ${ }^{19}$. Além disso, pode-se considerar que o então secretário já havia sofrido uma pequena derrota, pois pretendia que a proposição fosse votada pelo Congresso ainda em 1990, porém a votação só ocorreria no ano seguinte, após o recesso parlamentar.

A assinatura pelo presidente da República e o envio ao Congresso ocorreu no dia 22 de abril de 1991. Dois dias depois, Zico pedia demissão da secretaria de esportes, alegando não conseguir conciliar as atividades de secretario com seu tempo com a família. Em seu lugar, assumiu Bernard Rajzman, ex-jogador da seleção brasileira de vôlei. O novo secretário dizia apoiar o projeto de Zico e teria apoio, assim como Zico, de atletas profissionais, parte dos clubes e entidades que dirigiam esportes amadores, e resistência por parte da CBF, federações estaduais e parte dos grandes clubes do país ${ }^{20}$.

Mesmo com a demissão, Zico continuou atuando a favor do seu projeto. Em junho de 91, o ex-secretário foi até Brasília para defender a proposição e criticar a suposta tentativa de antecipação das eleições para presidente na $\mathrm{CBF}^{21}$, que teria como tentativa manter Ricardo Teixeira no cargo, o que não aconteceria, segundo o próprio Teixeira, se os 84 clubes das duas primeiras divisões pudessem $\operatorname{votar}^{22}$, como previa o projeto de Zico.

A ideia seria antecipar a eleição de janeiro de 1992 para setembro de 1991,

\footnotetext{
${ }^{18}$ Anteprojeto sofre resistências. Folha de São Paulo, Cidades/Esportes, 01 de dezembro de 1990.

${ }^{19}$ Zico diz que não muda projeto para o esporte. Folha de São Paulo, Esportes, 30 de novembro de 1990.

${ }^{20}$ Zico pede demissão; Bernard é o novo secretário. Folha de São Paulo, Brasil, 24 de abril de 1991.

${ }^{21}$ Zico vai a Brasília promover projeto. Folha de São Paulo, Esportes, 26 de junho de 1991.

${ }^{22} C B F$ quer antecipar eleição para presidente. Folha de São Paulo, Esportes, 26 de junho de 1991.
} 
pois antes de tal mês, acreditava a $\mathrm{CBF}^{23}$, o projeto não seria votado pelo Congresso Nacional. Uma assembleia extraordinária com as 27 federações que votavam para as eleições da CBF autorizou a alteração da data do pleito, que ficou para julho, e seria realizada com chapa única, a de Ricardo Teixeira. A entidade, por meio de seu diretor técnico, Domingos Legal, e seu diretor de patrimônio, Melquíades Mariano, afirmava que a antecipação não tinha relação com a proposição de Zico, e sim com um suposto calendário cheio no ano de 1992. Também dizia contar com o apoio dos clubes, através do Clube dos 13 - apesar de alguns clubes se manifestarem contra a manobra, como o Palmeiras, cujo presidente também era presidente do Clube dos 13, e Márcio Braga, presidente do Flamengo -, e que mesmo se os 84 clubes pudessem votar, Teixeira teria apoio ${ }^{24}$. Os mesmos representantes da entidade, apesar de negarem a relação do adiamento com a votação do Projeto Zico, faziam severas críticas aos pontos da lei do passe, afirmando que o fim do mecanismo levaria os clubes à falência, e também repudiavam o fim do CND.

Por parte da imprensa, o discurso era favorável ao que seria considerado uma evolução para o futebol brasileiro, que seria o projeto de Zico. A Folha de São Paulo, por exemplo, fez um quadro ${ }^{25}$ com os vencedores e perdedores em relação ao adiamento das eleições na CBF, colocando Teixeira, federações e Havelange como ganhadores e o "futebol brasileiro" como perdedor, alegando que este continuaria refém dos interesses pessoais de seus dirigentes. O jornalista Fernando Santos escreveu que haveria uma pressão de João Havelange sobre os parlamentares, em relação à votação do Projeto Zico. O então presidente da Fifa, e sogro de Ricardo Teixeira, teria avisado que tiraria o Brasil da Copa do Mundo, caso o projeto provocasse alguma interferência no mandato de seu genro. Inicialmente, Havelange pressionava o Brasil para se modernizar, adequando-se ao que era feito na Europa ${ }^{26}$. No entanto, o tema das mudanças na forma de eleger o presidente da $\mathrm{CBF}$, que aumentaria o número de clubes votantes, daria menos peso a clubes que sobreviviam de troca de favores com a entidade e ameaçava prejudicar Teixeira, fez com que a Fifa se opusesse ao projeto. O jornal ainda fez uma "anatomia" do futebol nacional,

\footnotetext{
${ }^{23} \mathrm{Ibid}$.

${ }^{24}$ Diretor da CBF diz que clubes apoiam Teixeira. Folha de São Paulo, Esportes, 13 de julho de 1991.

${ }^{25}$ Ibid.

${ }^{26}$ Crise reforça posição da Fifa contrária ao "Projeto Zico". Folha de São Paulo, Esportes, 08 de outubro de 1991.
} 
colocando-o como um corpo doente, começando pela cabeça, a CBF, passando pelo estômago, que seriam as federações, submissas à CBF e que teriam interesses "maléficos", até a situação dos clubes, que tinham que vender seus craques para o exterior para sobreviver. Ainda previa que o projeto de Zico seria facilmente rejeitado no Congresso, devido à pressão da Fifa, da $\mathrm{CBF}$, das federações ${ }^{27}$ e também de alguns clubes que estariam com medo de terem que se tornar empresas e praticar administrações competentes.

A antecipação das eleições na CBF acabou gerando críticas também por parte do governo, o que demonstrava a vontade do poder público de seguir o discurso modernizante. O secretário de esportes, Bernard Rajzman, considerava que a CBF estava tentando se desviar ${ }^{28}$ dos benefícios ao futebol que o projeto de lei traria e ainda considerava ilegal o fato de Teixeira ser eleito para mais quatro anos de mandato, sendo que já havia cumprido dois anos do mandato até então vigente, e que a lei em vigor (6251/75) falava em três anos, com possibilidade de reeleição para mais três.

O projeto seria analisado pela Comissão de Educação e Esportes da Câmara dos Deputados, que avaliaria eventuais emendas ao substitutivo do documento, apresentado pelo relator Artur da Távola (PSDB-RJ). Caso não houvesse emendas, o substitutivo iria diretamente para o Senado, para lá também ser analisado e votado. A Comissão queria aprovar o projeto na íntegra, ainda em 1991, para a futura lei vigorar em 1992. O presidente da Associação Portuguesa de Desportos e deputado federal pelo PRN, Arnaldo Faria de Sá, dizia que o projeto seria aprovado com mudanças na Câmara ${ }^{29}$, enquanto o jogador do São Paulo Futebol Clube, Raí, pedia que os parlamentares aprovassem o texto ${ }^{30}$.

A comissão aprovou o substitutivo do projeto, da maneira como foi proposto inicialmente, ao clube-empresa e não em relação ao passe. Os jogadores teriam passe livre a partir dos 28 anos de idade, conquistando $15 \%$ a partir dos 23 anos, com mais $15 \%$ a cada ano, e os $25 \%$ restantes aos 28 . Os contratos seriam de, no mínimo, 3 meses e, no máximo, 3 anos. A possibilidade de transformação dos clubes em empresas também foi aprovada. O que não passou foi a ampliação do colégio eleitoral

\footnotetext{
${ }^{27}$ Anatomia da crise. Folha de São Paulo, Esportes, 09 de outubro de 1991.

${ }^{28}$ Eleição na CBF é contestada em Brasília. Folha de São Paulo, Esportes, 31 de julho de 1991.

${ }^{29}$ Folha de São Paulo, Esportes, 05 de agosto de 1991.

${ }^{30}$ Folha de São Paulo, Esportes, 16 de dezembro de 1991.
} 
da CBF. O projeto tinha caráter terminativo e, por isso, teria ainda que aguardar cinco sessões para que qualquer deputado pudesse requerer a votação em plenário, antes de ir para o Senado.

Os clubes não queriam alteração em seu status jurídicos para sociedade comercial, pois tal mudança traria mais transparência nas negociações comerciais, pagamento de imposto sobre rendimentos líquidos, participação em campeonatos rentáveis e diminuiria o controle dos Conselhos Deliberativos sobre o departamento de futebol.

A Folha de São Paulo fez um quadro ${ }^{31}$, contendo uma espécie de classificação dos dirigentes de futebol no Brasil, sempre numa visão que criticava as práticas antigas e elogiava o que contribuísse para a modernização do futebol. Os tipos de dirigentes seriam: os marionetes, que seriam levados ao poder por pessoas impossibilitadas, por diversos motivos, de assumir o cargo, para defender os interesses destes últimos; os carreiristas, que teriam como meta tornar o cargo uma profissão, o que se daria mesmo em caso de contrariedade aos interesses dos clubes; os bicheiros, que usariam o esporte para lavagem de dinheiro do jogo do bicho; os paraquedistas, que seriam pessoas ricas, que nunca quiseram ser dirigentes, convidadas para assumir clubes endividados; os apaixonados, que seriam resquícios da época considerada amadora, e que usariam dinheiro do próprio bolso para ter um time vencedor; os mafiosos, que seriam capazes de qualquer coisa pelo seu clube, até mesmo desrespeitar leis; e os políticos, que usariam o futebol para influenciar eleitores e fazer carreira política.

Em 11 de novembro, assume um novo secretário de esportes. Dessa vez, Marcio Braga foi o escolhido. Justamente ele, que brigava constantemente com a CBF, e contra clubes que apoiavam a entidade, apoiando a aprovação do projeto Zico. Em entrevista à Folha de São Paulo, antes de assumir o cargo, Braga afirmava que priorizaria a aprovação do projeto, além da extinção do CND, que considerava uma intervenção estatal exacerbada, o que se encaixava na visão liberal que predominava na política nacional. O grande destaque da entrevista, no entanto, foi para a sinalização de Braga de que abriria espaço para alterações no projeto de Zico, numa possível tentativa de agradar clubes e federações que eram contrários, além da CBF. O secretário falava em fazer modificações para atender "reclames mais modernos do

\footnotetext{
${ }^{31}$ Folha de São Paulo, Esportes, 10 de outubro de 1991.
} 
que a lei propôs em sua época" ${ }^{32}$, sem especificar quais seriam tais reclames. Especificamente no que dizia respeito à CBF e a Ricardo Teixeira, Braga dizia ${ }^{33}$ :

“A relação nunca foi muito boa. Não só com Ricardo Teixeira, mas também com seus antecessores. Eu acho que com a modificação trazida pela "Lei Zico" vamos ter uma convivência perfeita: o Estado não tem nada que intervir nas entidades privadas."

Parece evidente no discurso de Márcio Braga que seria dado espaço para que a $\mathrm{CBF}$, e federações e clubes que a seguiam, tivessem seus interesses atendidos, dado o destaque do então secretário para o caráter privado destas entidades, que utilizavam com frequência o argumento que o Estado não poderia intervir em suas estruturas administrativas.

De fato, a votação na Câmara mostrou que houve recuo em medidas importantes do projeto, que entrou em pauta em tal casa em 26 de janeiro de 1993, depois de um ano e dez meses de sua apresentação, passando pelas comissões de Justiça e de Educação, Cultura e Desporto. A própria demora em sair uma definição já foi um sinal de derrota para as mudanças. Zico queria a aprovação do projeto ainda em 1991. Não conseguiu e a apreciação ficou para 1992, passando pelas comissões e sendo levada para a votação em plenário ${ }^{34}$, que ocorreu somente no início de 1993. Do total dos deputados à época, que era de 503, 352 compareceram à votação e 312 votaram a favor da aprovação.

A questão do passe passou por um processo de não decisão, pois a ideia do passe livre foi aprovada, mas a regulamentação ficou para decisão do ainda nem criado Conselho Superior do Desporto ${ }^{35}$. Como visto anteriormente, o projeto de Zico revogaria a lei 6.354/76, que dizia respeito às relações de trabalho dos profissionais do futebol e criava o passe, porém, a lei da época dos militares não seria mais revogada ${ }^{36}$. Era um ponto que incomodava muitos clubes, que se preocupavam com a perda de uma fonte de renda valiosa, além da perda técnica, com a possibilidade dos melhores jogadores serem facilmente levados para jogar em times mais ricos, como os

\footnotetext{
${ }^{32}$ Braga diz que vai priorizar "Lei Zico". Folha de São Paulo, Esportes, 02 de novembro de 1992.

${ }^{33} \mathrm{Ibid}$.

${ }^{34}$ Havia a possibilidade de o projeto ser votado sem passar pelo Plenário, como visto anteriormente, se não houvesse um pedido para tal. Mas o pedido foi feito e aceito.

${ }^{35}$ Câmara aprova projeto Zico "light". Folha de São Paulo, Esportes, 27 de janeiro de 1993.

${ }^{36}$ Questão do passe ainda está indefinida. Folha de São Paulo, Esportes, 01 de março de 1993.
} 
europeus. O secretário dos esportes, Márcio Braga, argumentava que a questão era muito importante e, por isso, não deveria ser "engessada",37.

Por outro lado, como previa Braga, a diminuição da intervenção estatal foi aprovada, pois o esporte profissional e o olímpico não seriam mais financiados pelo governo, mas apenas auxiliados. Foi aprovada a criação do Conselho Superior do Desporto, que substituiria o Conselho Nacional de Desportos (CND), e teria poder apenas consultivo e caráter colegiado, com seus 15 membros nomeados pelo presidente da República. A secretaria de esportes, que vinha sendo ameaçada de extinção, foi mantida. Por fim, a possibilidade de os clubes de futebol se transformarem em empresas foi aprovada e alguns clubes gostaram da decisão, como o Fluminense, que já havia aprovado, em seu estatuto, uma mudança no status jurídico para sociedade anônima ${ }^{38}$, o que faria com que $51 \%$ das cotas fossem mantidas para o clube e $49 \%$ passassem para acionistas particulares, e o São Paulo, cujo presidente à época, José Eduardo Mesquita Pimenta, planejava criar a "São Paulo S/A", sociedade anônima da qual o clube seria o principal acionista, composta por executivos remunerados e que visaria obter lucro ${ }^{39}$.

A maneira como o projeto foi aprovado na Câmara não agradou ao exsecretário, Zico ${ }^{40}$, que achou que houve muitas alterações, especialmente em questões cruciais como o fim do passe e a alteração na forma de votação de federações, que ficou aberta para estas definirem da maneira que achassem apropriada, e da CBF, que foi mantida como era, além de qualquer possibilidade de alteração imediata ter sido minada anteriormente, com a antecipação das eleições de janeiro de 1992 para julho de 1991, que terminou com a reeleição de Ricardo Teixeira. Para Zico, tal decisão representava um atraso. Ele achava que o futebol brasileiro seguiria sendo comandado por alguém que não teria qualificação nenhuma na área - referindo-se a Teixeira. Sobre o passe, considerava que os atletas teriam que batalhar muito para fazer valer seus interesses. Alguns deles manifestaram insatisfação com o que foi aprovado,

\footnotetext{
${ }^{37}$ Câmara cria "Lei Sarney" para o esporte. Folha de São Paulo, Esportes, 28 de janeiro de 1993.

${ }^{38}$ Ibid.

${ }^{39}$ Futebol do São Paulo pode se transformar em empresa. Folha de São Paulo, Esportes, 03 de dezembro de 1993.

40 “Jogadores vão ter que lutar”. Folha de São Paulo, Esportes, 28 de janeiro de 1993.
} 
como o então lateral do Corinthians, Giba, que considerou que não seria melhorada a situação dos jogadores ${ }^{41}$, que continuariam "presos" aos clubes.

$\mathrm{O}$ ex-secretário não foi o único a fazer críticas ao projeto. O deputado do PT do Rio Grande do Sul, José Fortunati, depois de ler o texto aprovado, o qual tinha a rubrica do relator Artur da Távola (PSDB-RJ) em todas as suas páginas, percebeu que foram alterados ${ }^{42}$ dois artigos, diferindo do que estava no texto quando os deputados analisaram a matéria, um que criava cargos a mais para a secretaria dos esportes e outro que foi suprimido, que destinaria $5 \%$ da renda dos jogos para o INSS, este reconduzido para outro projeto, que trataria da dívida dos clubes de futebol com a Previdência Social. Fortunati cobrou explicações de Artur da Távola e de Márcio Braga, que se mostrou a favor das alterações ${ }^{43}$ e não soube dizer quem seria o autor das mesmas. Alguns senadores já se mobilizavam para tentar barrá-las, como Eduardo Suplicy (PT-SP) e Humberto Lucena (PMDB-PB). O então ministro da Educação e do Desporto, Murílio Hingel, dizia que, em caso de aprovação dessas mudanças, no Senado, iria propor ao presidente Itamar Franco que as vetasse.

$\mathrm{O}$ relator negou que tivesse participação nas alterações e que teria apenas a tarefa de dar parecer oral do projeto substitutivo, apresentado pelos líderes do PDT, Éden Pedroso (RS), do PFL, Luís Eduardo Magalhães (BA) e do PP (então PSTR), Luiz Carlos Hauly (PR). Os senadores resolveram vetar as mudanças, em reunião entre os gabinetes de Pedro Simon (PMDB-RS) e de Eduardo Suplicy, e representantes do Ministério da Educação. Também seria modificada a composição do Conselho Superior de Desportos e seriam priorizados recursos para o esporte educacional. O senador do PT paulista ainda iria tentar aprovar emenda que propunha o passe livre para os atletas profissionais. Márcio Braga, pouco tempo depois, confessou ser o autor do pedido para a realização das alterações de última hora no projeto $^{44}$, mas não disse como foi possível realizar tal ato, que seria algo que foi decidido dentro do Congresso e que apenas queria dar uma estrutura melhor ao novo Conselho. Após o episódio, foi criado um novo substitutivo para ir ao plenário do Senado, que retirava as alterações, sem a participação de Braga, que havia participado

\footnotetext{
${ }^{41}$ Dirigente quer lei do futebol. Folha de São Paulo, Esportes, 28 de janeiro de 1993.

${ }^{42}$ Mudança na Lei Zico cria 42 cargos. Folha de São Paulo, Esportes, 30 de janeiro de 1993.

${ }^{43}$ Márcio Braga apoia emenda fantasma que cria 42 cargos. Folha de São Paulo, Esportes, 01 de fevereiro de 1993.

${ }^{44}$ Deputado Braga confessa autoria de cargos. Folha de São Paulo, Esportes, 04 de fevereiro de 1993.
} 
das discussões na Câmara e, dessa vez, foi substituído pelo assessor do ministro da Educação, Antônio Barbosa. Braga acreditava que estava sendo alijado do processo.

O projeto foi aprovado no Senado, porém com a adição de emendas, propostas pelo relator na Casa, Ronaldo Aragão (PMDB-RO) - que havia sido contemplado, dias antes, com uma viagem, bancada pela $\mathrm{CBF}$, para assistir a uma partida na Copa nos Estados Unidos - e a matéria foi enviada novamente para a Câmara dos Deputados. Apesar de algumas mudanças, como o aumento no número de membros do Conselho Superior de Desportos, o ponto da possibilidade de transformação dos clubes em empresas foi mantido, continuou existindo a chance de o fim do passe ser aprovado e a interferência estatal no esporte permaneceria diminuída.

Quando voltou à Câmara, para nova votação, foi aprovado com as mudanças colocadas pelo Senado. Foram introduzidos artigos que permitiam aos clubes praticarem a realização de bingos em suas sedes, desde que comprovassem atividades em três modalidades olímpicas. O bingo era uma antiga fonte de renda para os clubes, que não vinha mais sendo utilizada e, a partir dessa medida, poderiam voltar à ativa, mas sob o olhar da Receita Federal, o que fazia com que os clubes nem revelassem os valores dos investimentos, das arrecadações e dos repasses para as empresas contratadas para promover o jogo ${ }^{45}$.

O presidente Itamar Franco sancionou ${ }^{46}$ a lei em 06 de julho de 1993, com alguns vetos, como o do artigo que permitia deduzir do imposto de renda as contribuições feitas aos clubes esportivos, e a regulamentou em 11 de novembro, através do decreto 981/93. A questão do clube-empresa foi aprovada, e os clubes poderiam tornar seus times de futebol empresas ou sociedades anônimas e manter a parte social como clube. Quanto ao passe, o secretário Márcio Braga dizia que os atletas passariam a ter contratos regidos pela Consolidação das Leis do Trabalho, estariam livres para decidir sobre a cessão ou transferência do seu passe e ganhariam direito de arena, com a transferência para os jogadores de $20 \%$ do valor dos contratos de transmissão de imagens pela televisão. As entidades - clubes, federações e confederações - teriam 180 dias para se adaptar às novas regras. $\mathrm{O}$ discurso do secretário, voltado para o paradigma da modernização do esporte, era de que a nova legislação seria capaz de resolver o que ele e outros consideravam problemas

\footnotetext{
${ }^{45}$ Clubes fazem bingos para diminuir despesas. Folha de São Paulo, Esportes, 06 de março de 1994.

${ }^{46}$ Chega a hora do futebol-empresa. O Estado de São Paulo, Esportes, 08 de julho de 1993.
} 
estruturais do futebol brasileiro, que causariam os problemas em campo que a seleção vivia, com dificuldades para se classificar para a Copa do Mundo de 1994:

"A culpa é de quem? Do técnico que não consegue dar conjunto e eficiência ao time, da qualidade dos jogadores, que nessa hipótese não seria das melhores, ou da estrutura do futebol brasileiro? Não tenho dúvida alguma que é da estrutura, que se montou sob a proteção da legislação anacrônica e autoritária que o Congresso e o governo Itamar acabam de revogar com a promulgação da lei 8.672, a Lei Zico (...)

(...) A moderna legislação desportiva, que entrou em vigor há menos de 40 dias, facilitará a reestruturação do nosso futebol" (Márcio Braga, em texto publicado na Folha de São Paulo em 13 de agosto de 1993)

Haveria, no entanto, no ano de 1994, a emenda de revisão constitucional prevista na Constituição de 1988 que, segundo jornalistas escreviam à época ${ }^{47}$, seria vista como uma grande oportunidade para grupos que não queriam as mudanças que viriam com a Lei Zico conseguirem a aprovação de uma emenda que acabaria com a liberdade que a lei concedia, por meio da impossibilidade de criação de ligas, as quais tirariam poder das federações estaduais e da CBF. A possível emenda tinha o apoio da entidade máxima do futebol brasileiro, da Fifa, da Federação Paulista de Futebol e da Federação Fluminense de Futebol, e a oposição de Pelé, Zico, Telê Santana e Flamengo. Porém, a revisão constitucional acabou não resultando em tantas consequências ${ }^{48}$ de grande impacto, ao menos para o futebol. Apenas seis emendas foram aprovadas, pois o clima político não se mostrava favorável a mudanças, devido a casos como a CPI de PC Farias e a CPI do Orçamento, a qual resultou na cassação de deputados. Também a população havia decidido, em plebiscito, manter a república presidencialista e o presidente Itamar Franco não mostrava muito empenho em praticar mudanças. Havia, ainda, um temor de parlamentares da oposição de que se formasse novamente o "Centrão", trazendo ameaças aos direitos sociais conquistados na Constituição Cidadã. Devido a esses fatores, a revisão constitucional não teve muito impacto.

Para que pudesse ser concretizado numa lei (Lei n. 8672/93, "Lei Zico"), o

\footnotetext{
${ }^{47}$ Tirem o futebol das mãos dos amadores. Juca Kfouri, Folha de São Paulo, 24 de dezembro de 1993.

${ }^{48}$ O fracasso da revisão constitucional de 1994. Senado Notícias, 29 de janeiro de 2015. Disponível em: http://www12.senado.leg.br/noticias/materias/2008/08/19/o-fracasso-darevisao-constitucional-de-1994
} 
projeto de Zico foi alterado em relação ao que se idealizava inicialmente. Alguns pontos foram mantidos, mas amenizando os efeitos de algumas regras que trariam alterações grandes, como o fim da lei do passe. A missão de profissionalizar diversas práticas do futebol nacional acabou ficando como iniciativa dos próprios dirigentes dos clubes. De qualquer maneira, uma possibilidade de algo novo surgia, pois alguns clubes poderiam escolher transformar seus departamentos de futebol em empresas. Outras formas de gerar receitas acabaram surgindo no meio do processo, que não estavam nem presentes no projeto inicial, como a utilização dos recursos vindos dos bingos.

O processo que culminou com a Lei Zico já foi um momento chave nas políticas para o esporte no Brasil, e especificamente, para o futebol no país. Foi apresentado um projeto de uma lei que nortearia as políticas voltadas ao futebol, propondo o imediato fim do passe, que, após a tramitação, teve como destino ser extinto aos poucos, ao longo de alguns anos. Propôs também a transformação dos clubes em empresas, de maneira facultativa, o que foi aprovado.

Os grupos de interesse, neste caso, boa parte dos clubes, a CBF e as federações já demonstravam como seriam fundamentais para os resultados das decisões políticas. Eles interferiram de várias maneiras e sinalizaram como seriam os momentos seguintes. A atuação do governo, junto a uma convergência de interesses, envolvendo parte dos clubes, jogadores e alguns veículos da mídia, deveria ser muito mais intensificada para que se conseguisse algum resultado que alterasse o status quo. No entanto, o princípio de um discurso novo, voltado para a modernização do futebol, já era apresentado e proposto na arena política. Os anos seguintes seriam marcados por mais movimentações em torno desse discurso, e as relações de trabalho entre clubes e jogadores, assim como a administração dos clubes, seriam temas fundamentais no contexto das ações políticas que se dariam no âmbito das mudanças no mundo do futebol brasileiro.

\subsection{2) Lei Pelé}

Nesta seção, será analisado o debate que ocorreu em torno das principais questões que trazia o projeto que resultaria na chamada "lei Pelé". A ideia inicial do ministro extraordinário dos esportes, Pelé, era de dar passe livre aos atletas aos 27 
anos, em 1997. Porém, já na apresentação de uma proposta formal, que foi a resolução n.1, foram apresentadas diversas sugestões de mudanças, após reuniões entre ministério e clubes. Depois de discussões e acordo entre o ministro dos esportes e representantes dos clubes e de jogadores, o resultado final da resolução, foi o seguinte: ficou estabelecido o prazo de um ano para a resolução passar a vigorar e a liberação do passe para os atletas com 27 anos ocorreria a partir de 1 de janeiro de 1998. Em 1999, teriam passe livre atletas com 26 anos e, no ano 2000, aqueles com 25 anos.

Como a resolução não tinha poder de alterar a lei vigente, Pelé apresentou um novo projeto de lei, o 3633/97. O projeto continha as seguintes propostas: extinção do passe dois anos após a entrada em vigor da lei; tempo mínimo de contrato de 6 meses; multa de rescisão contratual de metade do valor do que seria pago ao jogador no restante do contrato; idade mínima para profissionalização de 15 anos; e transformação obrigatória dos departamentos de futebol dos clubes em empresas.

O projeto entrou na Câmara dos Deputados em regime de urgência, recebeu 127 emendas e teve o caráter de urgência retirado, após pressão de parlamentares ligados a clubes e à CBF, como Eurico Miranda, Ricardo Gomyde, Arnaldo Faria de Sá e Jovair Arantes, em reunião com o ministro. O relatório do projeto só foi aprovado depois que o relator acertou com os deputados contrários ao projeto a extensão do prazo para a lei vigorar, que ficou em três anos após a aprovação.

O substitutivo do relator foi aprovado na Comissão Especial que analisou o projeto, e depois, em plenário na Câmara, e no Senado, com mudanças no que foi proposto inicialmente por Pelé. Os clubes formadores de atletas poderiam exigir indenização em suas transferências; o primeiro contrato profissional teria que ser com o clube que formou o jogador; os clubes-empresas não precisariam pagar imposto de renda sobre o resultado financeiro se reinvestissem o lucro no próprio clube; e os clubes poderiam se tornar sociedades civis com fins econômicos - proposta de dirigentes de clubes - e o prazo para tal não seria mais um ano.

Para entender todo esse processo, é necessário relembrar que, em 1995, iniciase o mandato de um novo governo, com Fernando Henrique Cardoso (PSDB) como presidente, que cria um ministério extraordinário para a área do esporte. Pela primeira 
vez na história do Brasil, era criado um ministério exclusivo para tratar das questões relativas ao esporte. $\mathrm{O}$ escolhido do presidente para ser o ministro dos esportes era Edson Arantes do Nascimento, o Pelé. Artur Antunes Coimbra, o Zico, tivera apenas status de secretário dos esportes. Pelé já ganhou a posição de ministro. Essa característica já sinaliza que temas que envolviam o esporte seriam tratados mais de perto pelo Estado, a fim de garantir a execução de medidas liberalizantes na área. Grande parte do foco desse tratamento foi destinado ao futebol e a indicação de Pelé era um demonstrativo disso.

Pelé estava empenhado em promover mudanças significativas no futebol brasileiro, procurando liberalizar e profissionalizar o esporte. As medidas mais importantes mexeriam com as relações de trabalho entre clubes e atletas, e com a administração dos clubes. No caso das relações de trabalho, o ministro dizia já sentir, desde a época de jogador, que o mecanismo do passe prendia os jogadores aos clubes, cerceando a liberdade dos atletas de buscarem empregos que pudessem ser mais vantajosos para eles.

Um caso emblemático foi o do ex-jogador Afonsinho, que, na década de 1970, já se mostrava insatisfeito com seu clube e procuraria outro lugar para trabalhar. Seu time era o Botafogo Futebol e Regatas, que tinha como técnico Mário Jorge Lobo Zagallo. O técnico exigia que Afonsinho não se apresentasse usando barba para treinar e para jogar, o que o jogador não acatou, entendendo como um cerceamento de sua liberdade. A partir daí, ele começou a ter problemas com o clube, que o afastou, o colocou para treinar em separado e até mesmo o emprestou para um outro clube. Afonsinho entrou na justiça pedindo a concessão de seu passe junto ao Botafogo e, após muitas dificuldades, conseguiu a vitória (Florenzano, 1998). Porém, a ação não acabou desencadeando uma sequência de outras iniciativas de conquista do passe, em grande parte porque os jogadores não tinham respaldo de muitas pessoas ou instituições, o que os inibia, além da ameaça de ficarem sem trabalhar.

Aliada ao empenho de provocar mudanças no futebol, pela ideia que Pelé tinha de que, desde quando jogava, os jogadores já não tinham liberdade para trabalhar, a influência de um caso estrangeiro também inspirava o então ministro. Tratava-se da Lei Bosman, que referia-se à ação que o jogador belga Jean-Marc Bosman promoveu contra o Liége, clube de seu país, pelo qual atuava, por não 
conseguir se transferir para outro clube. Depois de alguns anos de trâmites, o jogador acabou recebendo veredito favorável, garantindo a livre circulação de jogadores no continente europeu, além de ter sido anulada a regra que limitava a três a presença de atletas estrangeiros em uma equipe (Giglio e Rubio, 2013). Nesse caso, portanto, a ação promovida por um jogador acabou desencadeando efeitos gerais, trazendo benefícios para qualquer jogador que estivesse "preso" a algum clube.

Antes de o ministro Pelé propor qualquer projeto, já existia um projeto de lei que propunha a extinção do passe nas relações de trabalho entre atletas e clubes. Era o Projeto de Lei n. 1159/95, apresentado pelo deputado Arlindo Chinaglia (PT-SP), que alterava a lei 6354/76, justamente aquela que criava o mecanismo do passe, além da lei Zico. O deputado considerava que o passe era uma maneira dos dirigentes fazerem valer seus interesses, com o intuito de intermediar negociações de atletas, fazendo dinheiro. Propunha o fim do passe e que a Justiça do Trabalho resolvesse as questões trabalhistas envolvendo jogadores profissionais. A iniciativa, no entanto, esbarrou justamente nos interesses desses dirigentes, e ficou parada, graças à ação do parlamentar Jovair Arantes (então PSDB-GO) que defendia interesses de um clube era vice-presidente do conselho deliberativo do Atlético Goianiense -, e foi relator da Comissão de Educação e Desporto, que analisava o projeto de Chinaglia, o qual ainda não tinha sido aprovado em tal comissão, o que atrasava qualquer chance de ser votado. $^{49}$

A primeira iniciativa do ministério, no sentido de apresentar algo institucional, foi, em 1996, com uma resolução, através do Indesp (Instituto Nacional de Desenvolvimento do Desporto), baixada por Pelé, que era esperada para vigorar a partir de 1 de janeiro de 1997, de maneira gradual. Os jogadores acima de 26 anos já teriam o passe livre em 1997. Em 1998, passariam a ter o direito os acima de 25 anos, e, em 1999, os de 24 anos. Tal configuração foi diferente do que ficou estabelecido com a Lei Zico, que era o passe livre aos 28 anos de idade, vindo de maneira gradual a partir dos 24 anos; também foi diferente do proposto inicialmente por Pelé, que seria dar passe livre aos atletas com 24 anos, já a partir de 1997.

\footnotetext{
${ }^{49}$ Líder do PSDB põe na comissão "inimigos" de Pelé. Folha de São Paulo, Esportes, 01 de outubro de 1997.
} 
A mudança resultou de discussões realizadas entre ministério e clubes. Ainda assim, a resolução sofreria resistência de clubes, mas apoio do sindicato dos atletas profissionais de São Paulo. Dirigentes de clubes fariam uma reunião com a Confederação Brasileira de Futebol (CBF) para pedir ação direta de inconstitucionalidade no Supremo Tribunal Federal contra a resolução. O deputado federal pelo PPB-RJ e dirigente do Vasco da Gama, Eurico Miranda, dizia que a lei do passe dizia respeito à lei de 1976, e que só poderia ser mudada após passar pelo Congresso. A proposta dos clubes era que a idade para o passe livre fosse de 28 anos e a carência para a entrada em vigor da possível nova lei fosse de três anos. O assessor de Pelé, Hélio Viana, dizia que aceitaria uma carência para adaptação dos clubes, mas que não de três anos, proposta que também não agradava aos sindicatos dos atletas do Rio de Janeiro e de São Paulo. ${ }^{50}$

Reagindo, Eurico Miranda apresentou um projeto de lei (2437/96) que dizia respeito aos mesmos temas envolvidos na resolução do ministério dos esportes, enfatizando os contratos de trabalho dos atletas profissionais. Queria que o Congresso Nacional pudesse fixar o valor, os critérios e as condições de pagamento do passe (Boudens, 2000). Achava que o fim do passe traria problemas perante a FIFA, desemprego para os atletas e escravização pelos empresários, e exigia que os clubes pudessem ter retorno do capital investido na formação dos atletas. Ainda dizia que os jogadores eram livres para aceitar ou não as condições dos contratos.

Depois de acordo entre o ministro dos esportes e representantes dos clubes e de jogadores, foi aceito o prazo de um ano para a resolução passar a vigorar e a liberação do passe para os atletas com 27 anos, a partir de 1 de janeiro de 1998. Em 1999, teriam passe livre atletas com 26 e, no ano 2000, aqueles com $25 \operatorname{anos}^{51}$. Quem tivesse 30 anos, a partir de 1997 já poderia ser dono de seu passe, além daqueles que tivessem o preço do passe fixado nas federações por mais de seis meses. A resolução n.1 foi assinada em meados de outubro de 1996, e não revogava a lei do passe, o que uma resolução não poderia fazer.

\footnotetext{
${ }^{50}$ Clubes contra-atacam o passe livre. Folha de São Paulo, Esportes, 17 de setembro de 1996. 51 "Lei Pelé" faz estreia e provoca discórdia. Folha de São Paulo, Esportes, 01 de janeiro de 1997.
} 
Pouco depois da assinatura da resolução, o então presidente do Botafogo, Carlos Augusto Montenegro, se posicionava, dizendo que poderia abrir mão do passe, desde que os contratos não tivessem limites de duração e houvesse proteção aos clubes nos casos de transferência para o exterior, pedindo um período de um ano e meio para que não precisasse mais existir o passe. Enquanto isso, a $\mathrm{CBF}$, depois de Assembleia Geral, decide determinar às federações e clubes que não aplicassem a resolução, e que continuassem a se basear na lei 6354, de 1976, no que se referisse ao regime jurídico do passe (Boudens, 2000), sob o argumento de que o Indesp não tinha poder legal para regulamentar a questão, o que era correto, pois uma resolução não poderia ditar uma norma que divergia da lei vigente e, de fato, a resolução do Indesp não teve esse poder.

Quanto aos jogadores, ainda que os sindicatos de atletas fossem a favor da proposta, grande parte dos jogadores se mostrava contra o fim do passe ${ }^{52}$, provavelmente por receio das equipes pequenas, as que empregavam a maioria dos atletas, acabarem perdendo o interesse em jogadores com idade acima de 24 anos. $\mathrm{O}$ presidente do Sindicato dos Atletas de São Paulo, Rinaldo José Martorelli, dizia:

"Essa categoria [a dos jogadores de futebol] tem um aspecto que dificulta a ação do sindicato. As diferenças salariais são muito grandes, o que torna os interesses dos jogadores também muito diferentes. Além disso, o passe intimida os jogadores de altos salários a tentar defender os que ganham menos. Eles temem ter a carreira prejudicada. [...] Os atletas estão mais preocupados com a sua profissão. A concorrência aumentou e o mercado quer jogadores com mais responsabilidade."53

Ao longo do ano de 1997, o ministério dos esportes elabora, baseado nas discussões que nortearam a assinatura da resolução n.1/96, um projeto de lei para mudar as regras que balizavam o esporte no Brasil. O projeto, de autoria do poder executivo, pelo ministro Pelé, era o de número 3633/97 e foi o texto que serviu de base às discussões e que foi levado ao Congresso, primeiramente à Câmara dos Deputados. Foi o projeto que mais prendeu a atenção, apesar de ter tramitado em

\footnotetext{
${ }^{52}$ Apesar de muitos jogadores considerarem o passe como um mecanismo escravizador (Correia, 2010).

${ }^{53}$ Proni, Marcelo Weishaupt."Esporte Espetáculo e Futebol Empresa". Tese de doutorado. Faculdade de Educação Física da Universidade Estadual de Campinas.1998. p. 243.
} 
conjunto com outros projetos que diziam respeito às regras do esporte brasileiro, como o PL n. 1159/95, de autoria do deputado Arlindo Chinaglia (PT), também o projeto n. 2437, de 1996, do deputado Eurico Miranda (PPB), além do projeto n. 3558, de 1997, do deputado Maurício Requião (PMDB). A lei resultante, todavia, foi muito mais parecida com o projeto de Pelé do que com qualquer outro destes citados. Ele criava novas regras para o desporto no país, revogando as leis 6354, de 1976, e a Lei Zico (8672/93). O projeto dizia respeito a matérias de diversas comissões temáticas, como Seguridade Social e Família, Trabalho; Educação, Cultura e Desporto; Constituição e Justiça; e Finanças e Tributação. Por esse fato, ele entra para uma Comissão Especial, o que fez com que algumas questões mais técnicas não fossem tão debatidas (Boudens, 2000).

A ideia inicial era que o passe seria extinto dois anos após a entrada em vigor da lei. O tempo mínimo de contrato seria de 6 meses e a multa de rescisão contratual equivaleria à metade do valor do que seria pago ao jogador no restante do contrato. A idade mínima para profissionalização seria de 15 anos e os pais precisariam acompanhar a assinatura dos contratos até os 21 .

Quanto à administração dos clubes, o projeto propunha tornar obrigatória a transformação dos clubes em empresas. Pelé também prometia estudar formas de renegociar as dívidas das entidades, que eram vistas como impossíveis de serem pagas, de tão grandes que eram, segundo o ministro. Os clubes seriam obrigados a virar empresas, ou, ao menos, transformarem seus departamentos de futebol em empresas, porque o futebol daria lucro e os clubes e dirigentes estariam se favorecendo disso, já que as entidades esportivas eram consideradas sem fins lucrativos, e por isso, tinham benefícios fiscais. ${ }^{54}$ Os clubes, as federações e a $\mathrm{CBF}$, novamente reagiram à proposição, por meio dos seus representantes no Congresso. Por exemplo, Eurico Miranda e Ricardo Gomyde (PCdoB-PR) apresentaram emendas, pretendendo acabar com a obrigatoriedade da transformação dos clubes ou de seus departamentos profissionais, propondo diminuir os efeitos da medida, ao reduzi-la a uma opção, não mais uma obrigação, de se tornarem empresas.

\footnotetext{
${ }^{54}$ Pagando impostos numa proporção menor do que empresas que tinham fins lucrativos. Por exemplo, apenas $5 \%$ da renda bruta das bilheterias ia para contribuições referentes a gastos com pessoal. Uma empresa pagava $20 \%$ de sua renda bruta para esse tipo de gasto.
} 
Um texto do projeto foi elaborado pelo membro do Conselho Administrativo do Indesp na época, Carlos Miguel Aidar, prevendo anistia dos débitos de tributação federal e isenção fiscal de 5 anos de tributos federais para os clubes de futebol, exceto FGTS e Imposto de Renda retido de seus funcionários. Aidar se dizia contra tal saída, mas apresentou de tal forma para atrair os clubes aos pontos mais importantes, como a transformação compulsória dos departamentos de futebol profissional em empresas. Porém, a Secretaria Geral da Presidência da República não aceitou as isenções fiscais para os clubes. A transformação em empresas, com isso, voltaria a ser opcional, e o governo ofereceria o parcelamento das dívidas referentes a tributos federais. Porém, com o projeto já em tramitação, voltou-se a ideia de os clubes que tivessem desporto profissional teriam que virar empresas. Ou o clube todo seria constituído sob a forma de sociedade comercial, ou teria que criar sociedade comercial para administrar todas as atividades ligadas às suas equipes profissionais ${ }^{55}$.

O projeto chegou à Câmara em outubro de 1997, com pedido para apreciação em regime de urgência. Mesmo com tal pedido, acabou sendo alvo de 127 emendas, destacando-se, quanto ao passe, as de autoria de Eurico Miranda, Arnaldo Faria de Sá (PPB-SP) e Jovair Arantes, que queriam restaurá-lo. Ricardo Gomyde (PCdoB-PR) queria quatro anos para o fim e Sandra Starling (PT-MG) queria o fim imediato. A urgência foi retirada por solicitação da Presidência da República no dia 4 de novembro de 1997, já que a manutenção do pedido poderia afetar a apreciação de outros projetos importantes para o Executivo, como a proposta orçamentária para 1998. Porém, em 9 de dezembro, a Câmara aprovou requerimento dos líderes, com pedido de urgência regimental. O relator do projeto foi Antônio Geraldo (PFL-PE), indicado pelo líder de governo, Inocêncio Oliveira (PFL-PE), que, naquele ano, profissionalizou um time de futebol em sua cidade, Serra Talhada (PE), para competir com um rival local, ligado ao governador de Pernambuco, Miguel Arraes (PSB).

A $\mathrm{CBF}$ e os 26 clubes da primeira divisão do campeonato brasileiro se reuniram, num esforço para obter aliados na base parlamentar de apoio ao governo. A expectativa era que não fosse difícil conseguir barrar os artigos sobre o passe e o clube empresa. Os clubes estariam conseguindo reunir vários deputados dedicados a combater o projeto e começavam campanha em TVs, rádios e jornais, criticando o projeto de lei. O presidente da $\mathrm{CBF}$, Ricardo Teixeira, começava a viajar para

\footnotetext{
${ }^{55}$ Pelé recebe projeto que anistia clubes. Folha de São Paulo, Esportes, 13 de maio de 1997.
} 
conversar com políticos que controlavam bancadas numerosas no Congresso, em particular do PSDB, base governista. Procurava até mesmo explorar divergências entre os partidos nos estados, se encontrando com o então prefeito de Contagem (MG) e ex-governador de Minas, Newton Cardoso. Ele seria possível candidato do PMDB ao governo do estado e adversário, dentro do partido, do prefeito de Juiz de Fora, Tarcísio Delgado. Teixeira também se encontrava com Delgado, naquela cidade, onde a CBF desenvolvia projeto de escolinhas de futebol ${ }^{56}$.

No Congresso, os clubes contabilizavam diversos deputados que tinham ligações com agremiações, como Darcísio Perondi (PMDB-RS), irmão do presidente da Federação Gaúcha de Futebol, Emídio Perondi, e Germano Rigotto (PMDB-RS) posteriormente eleito presidente da comissão especial que analisaria o projeto -, que teria sido eleito com votação expressiva da torcida do Caxias, clube contrário ao projeto $^{57}$. Ainda seria indicado, pelo líder do PSDB na Câmara, Aécio Neves - que se declarava a favor do projeto -, para a comissão que analisaria o projeto, dois deputados vistos como inimigos do ministério dos esportes: Jovair Arantes (GO) e Ricardo Johnson (PR). Arantes, como citado anteriormente, era vice-presidente do Conselho Deliberativo do Atlético Goianiense e havia sido relator na Comissão de Educação e Desporto do projeto do deputado Arlindo Chinaglia, que extinguia o passe, o qual ainda nem tinha passado pela primeira comissão.

Ricardo Teixeira fazia seu depoimento contra o projeto. Para facilitar o processo de negociação com os parlamentares, e para tentar convencê-los a barrar o projeto, a CBF montou uma "filial" em Brasília, que contava com campo de futebol iluminado e vestiários para os convidados, geralmente deputados federais, que se reuniam todas as terças-feiras no local, para churrasco e partida de futebol ${ }^{58}$.

No Executivo, FHC recebeu João Havelange, então presidente da FIFA e contrário ao projeto. Os dois almoçaram no Palácio das Laranjeiras, no Rio de Janeiro $^{59}$. Pelé procurava apoio no Congresso para a entrada do projeto em regime de urgência, o que tinha a oposição do relator do projeto. Este ouviria, na comissão

\footnotetext{
${ }^{56}$ Presidente da CBF visita ninhos tucanos. Folha de São Paulo, Esportes, 01 de outubro de 1997.

${ }^{57}$ Ibid.

${ }^{58}$ Lobby reserva lugar no estádio. Folha de São Paulo, 11 de novembro de 1997.

${ }^{59}$ Havelange chega a FHC antes de Pelé. Folha de São Paulo, 03 de outubro de 1997.
} 
especial, Pelé, João Havelange, Ricardo Teixeira, Zico, representantes de atletas, do Clube dos 13, dos árbitros e do Comitê Olímpico Brasileiro. A composição da comissão acabou agradando tanto governo como oposição. Nela, políticos que se encontravam em espectros ideológicos distintos tinham a mesma posição, defendendo seus clubes do coração.

Pelé aceitou retirar a urgência do projeto, para aumentar suas chances de aprovação, em acordo entre o ministro, Eurico Miranda, os líderes partidários e o presidente da Câmara, Michel Temer. A votação ficaria para o final de novembro e o plenário votaria em dezembro. A ideia de Pelé era que os clubes não tivessem mais do que reclamar, já que pressionavam muito por mais tempo para debater o projeto. Houve um início de uma rodada de negociações em almoço na residência do presidente da Câmara ${ }^{60}$.

$\mathrm{O}$ relator decidiu alterar pontos importantes do projeto para tentar ganhar apoio ao seu substitutivo, que seria votado pela Câmara nos próximos meses. Queria enfraquecer as resistências ao projeto. Destaca-se aqui a mudança do texto que acabaria com o passe. Continuava favorável à extinção, mas queria proteger os clubes que formavam jogadores. A ideia era que os jogadores deveriam ser obrigados a assinar o primeiro contrato de trabalho com o clube que os formou. Se o atleta não fechasse acordo com empregador, ele não poderia se profissionalizar. Com o objetivo de impedir que o clube impusesse valores muito baixos de salários ou contratos longos demais, seria incluído um parágrafo que afirmava que o valor da multa rescisória seria proporcional ao rendimento anual. Quanto maior fosse o tempo de contrato, menor seria a multa. Na "Complementação de Voto", dada na reunião de 10 de dezembro, o relator registrou as diversas etapas de elaboração do texto final:

“Apresentei o meu parecer em reunião da Comissão realizada em 4 de dezembro de 1997, concluindo por um substitutivo. Na reunião de 9 de dezembro de 1997, apresentei sugestões para uma nova versão do Substitutivo, que foi amplamente comentada e discutida por diversos deputados. Encerrada a discussão na reunião de 10 de dezembro, durante a réplica, aceitei novas alterações que surgiram dos acordos lá efetuados". (Boudens, 2000)

\footnotetext{
${ }^{60}$ Pelé cede urgência para buscar apoios. Folha de São Paulo, Esportes, 23 de outubro de 1997.
} 
Antonio Geraldo, o relator, considerou de extrema importância também o tempo para adaptação ao fim do passe que foi designado aos clubes. Ele considerava que o relatório de um projeto como o da lei Pelé, que provocaria muitas alterações significativas, não poderia ser aprovado sem que fossem realizados acordos. Nesse sentido, a questão do tempo de adaptação foi fundamental:

"O prazo para que a Lei entrasse em vigor foi fator determinante. Conversei com Pelé e disse a ele que só era possível aprovarmos o Relatório se concedêssemos um prazo razoável para que a Lei entrasse em vigor. O então Ministro Pelé me respondeu: "Confio em você. Faça o que você entender que deve fazer para aprovarmos". Agradeci pela confiança em mim depositada e concedi 3 (três) anos de prazo para que a "Lei que acabou com o passe do atleta profissional" entrasse em vigor, a partir da sua sanção."61

Era, então, assinado o substitutivo do relator, fruto de um consenso ${ }^{62}$ nascido das discussões em Brasília, com os principais atores sendo Antonio Geraldo, Germano Rigotto, Ronaldo Cezar Coelho, assessores de Pelé, líderes de partido, a Casa Civil da Presidência da República e Michel Temer, presidente da Câmara. Muitos deles trouxeram ideias das discussões com esportistas e dirigentes. As bases da proposta de Pelé eram mantidas, no entanto, mudando a permissão que os clubes que formassem os atletas pudessem exigir indenização em suas transferências. No projeto de Pelé, o passe seria extinto dois anos após a promulgação da lei. No substitutivo, o primeiro contrato profissional teria que ser com o clube que formou o jogador. O texto ainda dizia que os clubes-empresas não precisariam pagar imposto de renda sobre o resultado financeiro se reinvestissem o lucro no próprio clube. Queria enfraquecer as resistências ao projeto. Na comissão que analisava o projeto, ocorreram muitos depoimentos de dirigentes de confederações e de associações de clubes de futebol, como Fabio Koff, que sugeriu que os clubes pudessem se tornar

\footnotetext{
${ }^{61}$ Antonio Geraldo, em entrevista concedida ao autor, por meio eletrônico em 11/06/2014.

${ }^{62} \mathrm{Na}$ mesma entrevista, o relator afirmou que conseguiu convencer os deputados que representavam clubes de futebol, como Eurico Miranda, de que a lei Pelé "se transformaria numa importante ferramenta para a modernização do nosso futebol e demais modalidades esportivas".
} 
sociedades civis com fins econômicos, proposta que tinha o apoio do relator, que já havia falado com Pelé sobre tal opção. Antônio Geraldo entregou parecer favorável, com o substitutivo, à Comissão Especial que analisava o projeto. A comissão aprovou tal parecer que, já com o substitutivo, foi ao Plenário, onde foi aprovado no mesmo dia (Boudens, 2000).

O projeto seguiu para o Senado, onde passou a ser denominado PLC 78/97, entrando em caráter de urgência, com a matéria incluída em pauta de convocação extraordinária, em janeiro de 1998, e foi aprovado sem modificações, mantendo o texto que veio da Câmara dos Deputados, baseado no substitutivo de Antonio Geraldo. Algumas resistências foram apresentadas, especialmente por Artur da Távola (PSDB), e por Leomar Quintanilha (PPB-TO), relator do projeto na Comissão de Constituição e Justiça, que era presidente da Federação de Futebol de Tocantins, e propôs 25 mudanças no projeto, entre elas a colocação um prazo máximo, que não havia no projeto, de 10 anos de contrato do atleta, além da opção de mudança para empresa pelos clubes de maneira facultativa, podendo escolher a forma de sociedades civis com fins econômicos. No entanto, um acordo entre Pelé, os líderes e relatores, em que ficava prometido pela liderança do governo levar as recomendações de vetos e aprimoramentos para a regulamentação do presidente, fez o projeto ser aprovado por votação simbólica, apesar das críticas ao texto ${ }^{63}$. O acordo não agradou a todos os senadores, com Jader Barbalho que afirmou:

"Estamos vivendo uma situação surrealista. Não é possível ouvir dos relatores que as emendas procedem, mas que não são acatadas. Não sabia que Pelé ia conseguir driblar o processo legislativo". (Boudens, 2000)

A lei é sancionada em 24 de março de 1998, com alguns vetos que não foram posteriormente derrubados pelo Congresso Nacional. No resultado final, a lei que entraria em vigor teria algumas diferenças em relação ao que Pelé e seus assessores haviam imaginado inicialmente. Os clubes não teriam mais que virar empresas em um ano, mas dois. O vínculo principal do atleta seria o empregatício, não o desportivo, acabando juntamente com o fim da vigência do contrato, o que, significava, na

\footnotetext{
${ }^{63}$ Senadores ameaçam atrasar lei Pelé. Folha de São Paulo, Esportes, 22 de janeiro de 1998.
} 
prática, que, terminando o contrato de trabalho, não haveria mais passe. Mas, na vigência do contrato, o atleta continuaria vinculado ao clube, a não ser que pagasse uma indenização, a multa rescisória, que teria os valores estabelecidos de acordo com o valor do contrato, que teria duração máxima de 2 anos. Quanto maior fosse o tempo de contrato, menor seria a multa. Os jogadores deveriam ser obrigados a assinar o primeiro contrato de trabalho com o clube que os formou. Se não fechasse acordo com empregador, ele não poderia se profissionalizar. Foram algumas contrapartidas que os clubes conseguiram, mas, de qualquer maneira, o projeto foi aprovado rapidamente, pela vontade do governo, dando algumas garantias aos clubes, mas, de fato, provocando uma mudança real na situação da relação de trabalho entre atletas e clubes, já que os jogadores, ainda que mediante o pagamento de uma indenização aos clubes, poderiam se desligar deles e procurar outro local para trabalhar. Não estariam mais, após o prazo de três anos da entrada em vigor da lei, presos pelo passe.

A lei foi regulamentada pelo decreto n. 2574, de 29 de abril de 1998. Mesmo após a regulamentação, ainda houve muita movimentação em torno de pontos que envolviam as relações de trabalho entre os jogadores e os clubes. Representantes de clubes continuavam afirmando que seriam muito prejudicados, pois perderiam atletas para times do exterior. É o caso de Eurico Miranda e de Zezé Perrella, dirigente do Cruzeiro, que acabava de ser eleito deputado federal, nas eleições de 1998. Perrela foi derrotado por Miranda para presidir uma subcomissão na Câmara que serviria para atacar a Lei Pelé, mas essa derrota não significava muito para o novato deputado, já que tanto ele como Miranda eram contra o fim do passe e ambos pretendiam derrubá$10^{64}$. A própria CBF já se movimentava para mudar a questão, além de outras, como o clube-empresa. Na Assembleia que reelegeu Ricardo Teixeira como presidente, foi realizado um acordo para propor alterações na lei, em que clubes e entidades se fortaleceriam para pressionar em tal sentido ${ }^{65}$.

Grandes clubes do Rio de Janeiro - Fluminense, Vasco e Botafogo - pediam ampliação no prazo para virarem empresas e a volta do passe. Os três, juntamente com o Flamengo, queriam a ampliação do tempo máximo de contrato, então de dois

\footnotetext{
${ }^{64}$ Miranda vai presidir subcomissão anti-Lei Pelé. Folha de São Paulo, Esportes, 16 de abril de 1999.

${ }^{65}$ Reeleição na CBF gera ação anti-Lei Pelé. Folha de São Paulo, Esportes, 02 de julho de 1999.
} 
$\operatorname{anos}^{66}$. Já o Clube dos 13 intensificava a atuação no Congresso para mudar a lei. A entidade aceitava o fim do passe, mas pedia a exigência de multas rescisórias elevadas, com acordo entre as partes ${ }^{67}$. Projetos de emenda à Lei Pelé seriam apresentados à Câmara. O deputado federal Mendes Ribeiro Filho (PMDB-RS) já havia apresentado projeto que previa uma tabela escalonada de ressarcimento aos clubes, no caso de um jogador rescindir unilateralmente o contrato. A escala diminuiria com o aumento da idade do atleta e a multa seria baseada nos valores fixados previamente ao contrato ${ }^{68}$. A CBF continuava se mexendo para debater a lei, encomendando um seminário da Fundação Getulio Vargas, para propor mudanças no futebol brasileiro. Boa parte das pessoas que participaram do seminário era contrária à Lei Pelé, como Eurico Miranda, Eduardo José Farah, presidente da Federação Paulista de Futebol, Eduardo Viana, presidente da Federação de Futebol do Rio de Janeiro, Fabio Koff, presidente do Clube dos 13, e Mustafá Contursi, presidente do Palmeiras ${ }^{69}$.

Com a Lei Pelé sancionada e regulamentada, também o debate sobre o fim do futebol amador nos clubes do País se adensou. A desejada lei era tida como o meio necessário para profissionalizar o esporte no país, propondo, além da extinção do passe, tornar obrigatória a transformação dos clubes em empresas. Depois de aprovada a lei, não faltaram propostas para solucionar o problema. Em 1999, uma proposta do deputado Ronaldo Cezar Coelho (PSDB-RJ) previa que os clubes que recebessem em suas instalações estudantes da rede pública para aulas de prática desportiva teriam as dívidas perdoadas com a Receita Federal e a Previdência Social ${ }^{70}$.

Muitos clubes continuavam pressionando o poder público para tentar promover mudanças no que foi decidido para a nova lei, enfatizando o caráter facultativo da transformação em empresas. Eles pediam mais tempo para se adequar e alegavam que os clubes pequenos seriam prejudicados. Alguns chegaram a contratar empresas, para atuar em parceria nos negócios do futebol, como Corinthians e

${ }^{66}$ Clubes do Rio tentam anular Lei Pelé. Folha de São Paulo, Esportes, 09 de dezembro de 1999.

${ }^{67}$ Clube dos 13 agora abre mão do passe por multa. Folha de São Paulo, 05 de março de 2000

${ }^{68}$ Ibid.

${ }^{69}$ Sem oposição, CBF debate a Lei Pelé. Folha de São Paulo, Esportes, 10 de março de 2000.

${ }^{70}$ Futebol no vermelho: problema privado, solução pública. O Estado de São Paulo, 24 de maio de 2014. 
Cruzeiro, com a parceria com a Hicks Muse e, Flamengo e Grêmio, com a ISL. As empresas ajudavam os clubes financeiramente, inclusive para contratar jogadores caros, porém, os clubes não transformavam seus departamentos de futebol, que continuavam amadores. Não podiam, assim, ser enquadrados na medida do governo, que proibia uma empresa de controlar mais de um time ${ }^{71}$.

\subsection{3) Lei Maguito Vilela}

Nesta seção, será reconstituído o debate que se deu em torno dos principais pontos que o projeto da chamada "lei Maguito Vilela" propôs. O principal objetivo do projeto de Maguito Vilela era alterar alguns pontos da lei Pelé, como derrubar a obrigatoriedade da transformação dos clubes em empresas e estabelecer uma indenização pelas vendas dos atletas, chamada de cláusula penal, como forma de recompensar os clubes pelo dinheiro investido na formação ou na compra de jogadores. Depois de passar por uma Comissão Mista, foi aprovada a cláusula penal e a permissão para os clubes formarem empresas, desde que não colocassem seu patrimônio nelas, nem deixassem de ter o controle acionário. Ficou proibido uma mesma empresa administrar mais de um clube, os clubes teriam que manter pelo menos $51 \%$ do capital votante e apenas dirigentes eleitos poderiam assinar contratos em nome do clube ou clube-empresa.

Maguito Vilela, então senador, ex-governador do estado de Goiás, pelo PMDB, e ex-vice-presidente da CBF, era relator de uma comissão no Senado, iniciada em 20 de janeiro de 2000, criada para analisar a Medida Provisória 2.011, que proibia uma mesma empresa de ter o controle sobre mais de um clube. Propôs a realização de audiências públicas com dirigentes de clubes, de federações, jornalistas esportivos e especialistas em futebol para discutir os efeitos da MP no esporte, no país. Paulo Marinho (PFL-MA) era indicado pelo partido para ser o presidente da comissão, substituindo Zezé Perrella (PFL-MG), então presidente do Cruzeiro, que havia renunciado ao posto. Mais dirigentes ou parlamentares ligados a alguns deles compunham a comissão, como Eurico Miranda (PPB-RJ), então vice-presidente do

${ }^{71}$ Clube-empresa.Folha de São Paulo, Esportes, 28 de janeiro de 2000. 
Vasco, contrário à proibição anunciada pela MP, e o próprio Vilela, que era ligado ao clube Jataiense-GO ${ }^{72}$.

O senador acreditava que era "uma agressão obrigar o clube a se transformar em empresa" 73 e propôs, na comissão, que fosse derrubada a obrigatoriedade estabelecida pela lei Pelé. Prometia ouvir até mesmo líderes de torcidas organizadas, alegando a possibilidade de toda a torcida não ser a favor da transformação dos clubes em empresas. Afirmava que manteria, em seu parecer, o ponto da MP que proibia uma mesma empresa de controlar mais de um clube de futebol, mas iria permitir que um mesmo grupo econômico financiasse vários tipos de modalidades esportivas. Pretendia entregar seu relatório ao plenário do Senado em 30 dias ${ }^{74}$. Porém, em março, o projeto ainda estava na comissão, depois de ser alvo de audiências públicas, e a primeira versão do substitutivo do relator ainda estava por ser apresentada. Haveria votação de artigos em separado, caso os parlamentares apresentassem emendas e houvesse discordâncias. Em caso de aprovação na comissão, seria votado em reunião conjunta do Congresso Nacional e, com nova aprovação, iria para sanção do presidente Fernando Henrique Cardoso.

Parte da imprensa considerava a proposta da não obrigatoriedade de clubes se tornarem empresas uma vitória para o que chamava de "setores mais conservadores", que seriam o Clube dos 13, Eurico Miranda e clubes que praticavam esportes olímpicos. Por outro lado, considerava uma derrota para esses setores o fato de não terem conseguido aprovar a volta do passe, já que havia muita resistência a tal medida dentro da comissão. O deputado Gilmar Machado (PT-MG) acreditava que o mais provável seria a alteração da fórmula de cálculo da multa rescisória, a qual os clubes consideravam muito baixa e pressionavam para que fosse aumentada. Machado propunha, ainda, que as empresas que adotassem parcerias com os clubes de futebol fossem taxadas, para que o dinheiro vindo de tal cobrança - bem como o vindo de outras receitas dos clubes, como o de transmissão de partidas pela TV - fosse investido na formação de atletas, através de um fundo nacional a ser criado, que

\footnotetext{
${ }^{72}$ Senador propõe que empresas invistam em vários esportes. O Estado de São Paulo, Esportes, 21 de janeiro de 2000.

${ }^{73}$ Senador quer tornar facultativo o clube-empresa. O Estado de São Paulo, Esportes, 28 de janeiro de 2000.

${ }^{74}$ Comissão deve votar até o dia 15. Folha de São Paulo, Esportes, 29 de março de 2000.
} 
remuneraria os clubes formadores. Já Vilela propôs alteração na Constituição ${ }^{75}$ para que dirigentes de federações e confederações pudessem exercer mais de dois mandatos consecutivos.

A imprensa, em grande parte, continuava a se mostrar favorável a medidas que, em sua visão, contribuiriam para a modernização do país e afastaria dirigentes antiprofissionais ou mal intencionados. O ex-jogador e colunista da Folha de São Paulo, Tostão, argumentava em tom crítico ao projeto de Maguito Vilela:

"No lugar de melhorar a Lei Pelé, o senador Maguito Vilela, relator do processo, auxiliado por Eurico Miranda, diretor do Vasco, e Zezé Perrella, presidente do Cruzeiro - ambos legislando em causa própria -, quer destruir o que existe de bom na lei. O relatório propõe o fim da autonomia dos clubes e acaba com a esperança de se formar uma liga forte, já que as federações e a CBF terão de aprová-la. A escravidão continua com o passe preso, disfarçado, uma vez que o relatório prevê multas altíssimas em caso de rescisão de contrato. A proposta também pede o fim da obrigatoriedade de o clube se transformar em empresa. Isso estimula os desorganizados clubes atuais a continuarem como estão. Gostaria que o Congresso Nacional e o presidente da República vetassem esse projeto retrógrado, mas não tenho esperanças." (Tostão, em O Pensador e o passe em curva, Folha de

São Paulo, Esportes, 19 de abril de 2000)

Pode ser percebido até mesmo um tom de cobrança em relação ao poder público, quando manifesta o desejo de o Congresso e o presidente vetarem o projeto. Porém, o discurso tende a exagerar no diagnóstico, porque, por mais que existisse a intenção de introduzir multas rescisórias muito altas, na prática elas não evitaram que os jogadores conseguissem ser liberados dos clubes para atuar em outros no Brasil e no exterior. Pelo contrário, o número de transferências cresceu muito nos anos 1990 e 2000. Também a não obrigatoriedade em transformar os clubes em empresas não era uma garantia de que nenhum clube se interessasse por gestões mais equilibradas financeiramente e profissionais. Certamente, alguns aproveitariam para não realizar nenhuma mudança em suas estruturas, usando o argumento da autonomia. Mas a possibilidade oferecida aos clubes já poderia permitir que as entidades que quisessem se transformar em empresas, ou praticar parcerias com elas, tivessem a estrutura legal

\footnotetext{
${ }^{75}$ Passe só acaba em 2001, diz comissão. Folha de São Paulo, Esportes, 07 de abril de 2000.
} 
para tanto, como fizeram alguns clubes, por exemplo, o Palmeiras, na parceria com a Parmalat.

Os clubes conseguiram que fosse criada uma regra de transição para se adaptarem ao fim do passe, além de uma medida provisória, que viraria uma nova lei do esporte. A comissão que elaborava o projeto de substituição derrubaria a obrigatoriedade do clube-empresa e a questão das cláusulas penais gerava polêmica. Os deputados queriam manter as regras da CLT e os clubes não, por se considerarem em desvantagem em relação aos clubes do exterior ${ }^{76}$. Pelo projeto, o prazo para o fim do passe continuava, mas respeitando o fim da vigência dos contratos firmados antes de 26 de março de 2001, data em que passaria a vigorar a lei. Ainda entrava no projeto o estabelecimento de multas rescisórias elevadas, apesar de que o texto apresentava problemas de redação nesse ponto, reconhecidos pelo próprio autor, que dizia que os valores ficariam menores. O presidente Fernando Henrique Cardoso prometia vetar qualquer alteração à Lei Pelé, e o ex-ministro (havia deixado o ministério em 1998, para comentar a Copa do Mundo pela TV Globo), recusou convite para comparecer ao Congresso e defender a lei que levava seu nome.

Após as discussões no Congresso, a Comissão Mista que analisou o projeto procurou assegurar uma forma de compensação aos clubes pelo investimento que eles realizavam na formação profissional dos atletas. É promulgada, então, a lei n. 9981, em 14 de julho de 2000, conhecida como "Lei Maguito Vilela", muito influenciada por parlamentares defensores dos interesses dos clubes. Ela alterava alguns pontos da Lei Pelé. A principal novidade era a criação da cláusula penal, nos casos de transferência nacional e internacional, a ser paga pelo atleta ou pelo clube interessado em contratá-lo. O valor a ser pago em caso de rescisão de contrato, pela cláusula penal, ficaria limitado a cem vezes o montante da remuneração pactuada no contrato, não havendo limite em casos de transferências para o exterior. Se o rompimento do contrato se desse pelo clube, estava prevista uma multa rescisória a ser recebida pelo atleta. Alguns consideraram a cláusula penal um "novo passe" (Correia de Melo e Correia de Melo, 2006), mas não se tratava da mesma coisa. Os jogadores não teriam a liberdade de poder sair de um clube a qualquer momento, sem custo, mas poderiam interromper os contratos, mediante o pagamento da indenização, sem ter que

\footnotetext{
${ }^{76}$ Passe só acaba em 2001, diz comissão. Folha de São Paulo, 07 de abril de 2000.
} 
completar 32 anos de idade. Os prazos dos contratos passariam do mínimo de três meses e máximo de dois anos para mínimo de três meses e máximo de cinco anos. Conforme desejavam os clubes, os contratos ganharam períodos maiores.

Fernando Henrique Cardoso vetou um artigo que fixava em quatro anos o tempo do primeiro contrato de um jogador formado nos próprios clubes e também a prerrogativa dos clubes de estipularem o valor da multa rescisória. Também voltava a valer a permissão de contrato de no máximo dois anos para jogadores formados no próprio clube, conforme original da lei Pelé.

O projeto do senador Maguito Vilela propunha ainda que os clubes poderiam formar empresas, desde que não colocassem seu patrimônio nelas, nem deixassem de ter o controle acionário, usando a Constituição para defender a autonomia dos clubes. A lei aprovada não difere muito do que foi proposto nesse ponto. Não houve veto para a proibição de uma mesma empresa administrar mais de um clube (alguns dirigentes, como Zezé Perrella, eram contra esse ponto). Também manteria a mudança de que o clube teria que manter pelo menos $51 \%$ do capital votante e apenas dirigentes eleitos poderiam assinar contratos em nome do clube ou clube-empresa, o que favorecia a manutenção das gestões dos clubes como eram tradicionalmente.

Pelé não queria seu nome na nova lei e criticou a maneira como foi aprovado o projeto, principalmente na questão trabalhista entre clubes e atletas, em que o exministro considerava que a "escravidão" que o jogador brasileiro sofreria, iria continuar acontecendo. Ele não deixou de culpar os atletas por isso, contrapondo uma possível apatia e uma falta de ação, por parte deles, ao forte lobby que os clubes teriam feito no Congresso Nacional:

“Os jogadores também são culpados. Durante a discussão sobre a lei, os clubes se organizaram, colocaram seus parlamentares para defender seus direitos, para fazer lobby no Congresso. Vocês viram algum jogador se manifestar contra a lei? Eles são omissos e vão ter que pagar por isso." 77

\footnotetext{
${ }^{77}$ Pelé culpa FHC por "escravidão" de atletas. Folha de São Paulo, Esportes, 31 de agosto de 2000.
} 


\subsection{4) CPIs do Futebol ${ }^{78}$}

\section{a) CPI da CBF/Nike na Câmara dos Deputados}

O ano de 2000 acabou sendo turbulento para o futebol brasileiro. Além da aprovação da Lei Maguito Vilela, que diminuía alguns avanços conseguidos pela Lei Pelé, duas Comissões Parlamentares de Inquérito foram instaladas no Congresso Nacional. Uma, para analisar os contratos entre CBF e a empresa de material esportivo "Nike", chamada de CPI da CBF/Nike, realizada pela Câmara dos Deputados. A outra, para analisar irregularidades no futebol brasileiro em geral, instalada no Senado e conhecida como CPI do Futebol.

A dissertação não pretende fazer um estudo pormenarizado das CPIs, mesmo porque elas abrangem um material bastante extenso que poderia resultar em um estudo específico sobre o tema. O que interessa aqui é destacar o que foi importante para as questões centrais abordadas, que dizem respeito ao processo de modernização do futebol brasileiro, especificamente as relações de trabalho entre clubes e atletas, e a administração das entidades desportivas.

Apesar de tratarem de temas associados às relações de trabalho, como um esquema de transferência de jogadores para o exterior, e as atividades dos empresários de futebol, as CPIs trataram mais das questões que envolvem a administração de clubes, federações e CBF, já que realizaram investigações profundas sobre a situação administrativa e financeira destas entidades, e propuseram que órgãos como a Receita Federal e o Ministério Público as investigassem e também propuseram mudanças na maneira de lidar com a gestão das entidades. Essas investigações e propostas de mudanças muito se relacionam com o tema da modernização do futebol, porque as CPIs fizeram sugestões e até mesmo idealizaram um novo projeto de lei para o esporte, voltadas para a maneira moderna de administrar as entidades, marcada pelo intenso profissionalismo e afastamento do considerado antigo amadorismo.

\footnotetext{
${ }^{78}$ Todas as informações referentes às CPIs foram extraídas da leitura dos relatórios de ambas em: Senado Federal. Relatório Final da Comissão Parlamentar de Inquérito. Criada por meio do Requerimento $n$. 497, de 2000-SF, "destinada a investigar fatos envolvendo as associações brasileiras de futebol”. Brasília, 2001. e

Câmara dos Deputados. Comissão Parlamentar de Inquérito Destinada a Apurar a Regularidade do Contrato Celebrado entre a CBF e a Nike. Brasília, junho de 2001.
} 
A CPI da CBF/Nike tinha como presidente o então deputado federal Aldo Rebelo (PCdoB-SP), como relator o deputado Silvio Torres (PSDB-SP), primeiro vice-presidente Nelo Rodolfo (PMDB-SP), segundo vice-presidente Pedro Celso (PTDF) e terceiro vice-presidente Eurico Miranda (PPB-RJ) que, como visto anteriormente, era bastante atuante na defesa dos clubes, especialmente para evitar que fossem adotadas medidas que mudassem a lei do passe e que fizesse com que os clubes tivessem gastos com impostos. Destaca-se, ainda, a participação de outros deputados que atuaram em outras questões aqui tratadas, como Darcísio Perondi (PMDB-RS), José Rocha (PFL-BA), Dr. Rosinha (PT-SP) e Luciano Bivar (PSL-PE), que foi presidente do Sport Club Recife em 1989-90, 1997-98 e em 1999-2000, renunciando em $2001 .^{79}$

O objetivo da comissão era analisar, além das relações estabelecidas entre a CBF e a empresa Nike, contratos da entidade com outros patrocinadores, sua administração, relações com as federações estaduais, com empresários e políticos. No total, foram realizados 125 depoimentos. O discurso adotado era de que seria uma ação moralizadora para o futebol nacional:

Ao encerrar essa tarefa, que não contém a pretensão de preencher todas as expectativas da sociedade, estou convicto de que a CPI CBF/NIKE vai dar uma importante contribuição para que a ética, a transparência e o interesse público sejam valores essenciais para habilitar as pessoas e entidades que pretendam comandar o futebol brasileiro e levá-lo à condição de líder inquestionável do futebol mundial. ${ }^{80}$

No contexto do elevado crescimento da comercialização do futebol, a CPI foi motivada por eventos que ocorreram em anos anteriores, que denunciavam práticas irregulares, como a denúncia de Pelé que afirmou, em 1994, que, ao sua empresa, a Pelé Sports, tentar comprar os direitos de transmissão do campeonato brasileiro de tal ano, recebeu uma solicitação de propina vinda do então diretor financeiro da CBF, José Carlos Salim, no valor de um milhão de dólares, a serem depositados num banco na Suíça. A empresa que acabaria levando vantagem na compra de tais direitos era a Traffic, do ex-jornalista esportivo e empresário, José Hawilla. A Traffic acertou

\footnotetext{
${ }^{79}$ Também foi presidente do Sport em períodos posteriores ao da CPI, em 2005-06 e 2013-14. Fonte: http://terceirotempo.bol.uol.com.br/que-fim-levou/luciano-bivar-5827

${ }^{80}$ Palavras do relator, Silvio Torres em: Câmara dos Deputados. Comissão Parlamentar de Inquérito Destinada a Apurar a Regularidade do Contrato Celebrado entre a CBF e a Nike. Brasília, junho de 2001. pp. 8.
} 
contratos de exclusividade para intermediar alguns direitos da $\mathrm{CBF}$, o que se tornaria um monopólio por parte da empresa. Outros fatos relevantes serviram de inspiração para a instalação da CPI, como o que ficou conhecido como "Vôo da muamba", em que houve, na volta da Copa do Mundo de 1994, uma tentativa, por parte da delegação da seleção brasileira, de entrar no país com 17 toneladas de bagagens, sem passar pela alfândega; e também um escândalo de arbitragem, envolvendo o responsável pela Comissão Nacional de Arbitragem da CBF, Ivens Mendes, acusado de graves irregularidades.

O que se torna o motivo principal para a proposta de instalação da CPI é o contrato firmado entre CBF e Nike, em 1996. O contrato era de patrocínio e apoio e foi intermediado pela Traffic Assessoria e Comunicações. A Nike se tornava copatrocinadora da CBF, junto com a Coca-Cola, e poderia usar a imagem da seleção brasileira de futebol e ser patrocinadora e fornecedora exclusiva de material esportivo da CBF. O relatório da CPI agradecia à imprensa pelo apoio e citava setores da mesma que costumavam se empenhar no apoio à medidas que "modernizassem" o futebol brasileiro, como a Folha de São Paulo, por meio da coluna do jornalista Juca Kfouri, que fazia uma série de questionamentos à exclusividade que a Nike tinha com a seleção, ampliando a crítica para possíveis interferências que a empresa praticava em convocações, escalações e escolha de adversários. Todos esses eventos citados e, especificamente, esse da ingerência da Nike na escolha de jogos e adversários da seleção, motivaram o deputado Aldo Rebelo, em 11 de março de 1999, a enviar requerimento ao então presidente da Câmara, Michel Temer, solicitando a abertura da CPI para investigar o contrato da empresa com a CBF.

A instalação da CPI logo foi questionada pela CBF, que exerceu forte oposição a tal fato, baseada no insistente argumento de seu presidente, Ricardo Teixeira, de que a entidade era de direito privado $^{81} \mathrm{e}$, portanto, não poderia ser investigada pelo Congresso Nacional. O relatório da CPI dá conta de que a CBF procurou reunir deputados, dirigentes de futebol, artistas e treinadores para minar a proposta. Segundo o documento, Teixeira convenceu o treinador da época, Wanderley Luxemburgo, e o ex-treinador, Mario Jorge Lobo Zagallo, a enviarem cartas à Câmara dos Deputados negando qualquer interferência da Nike na seleção. Uma série de

\footnotetext{
${ }^{81}$ Apesar de, no próprio depoimento de Teixeira na CPI, o então presidente se referir à entidade como uma empresa.
} 
deputados que tinham subscrito o requerimento para a instalação da comissão teriam sido pressionados a retirarem suas assinaturas, o que foi feito, restando, no entanto, 206 assinaturas, fazendo com que a CPI pudesse ser criada, pois eram necessárias 171 assinaturas. Ocorre que, de imediato, não foi efetivada a instalação, pois foram desarquivadas CPIs criadas na legislatura anterior, que haviam sido encerradas em 1998; que foram aprovadas, mas não instaladas; e que foram abertas às pressas, segundo o relatório. Como o limite previsto pelo regimento interno da Câmara era de cinco CPIs simultâneas, a da CBF iria passar mais 19 meses em espera, pois havia ficado para trás, passando de segunda para oitava na fila.

Depois que novas informações indicando ainda mais interferência da Nike na seleção passaram a ser veiculadas, como a acusação de que Wanderley Luxemburgo intermediava vendas de jogadores brasileiros para o exterior, sonegava ganhos ao Imposto de Renda e convocava jogadores para a seleção somente com o intuito de valorizá-los comercialmente, para depois vendê-los para times do exterior, a CPI foi finalmente criada, em 16 de outubro de 2000.

O primeiro ponto discutido foi a possível falta de democracia existente na Confederação Brasileira de Futebol. O relatório aponta que os presidentes das entidades filiadas à instituição não conheciam os negócios da $\mathrm{CBF}$, utilizando como exemplo os casos do então presidente da Federação Cearense de Futebol, que afirmara que os presidentes das federações não haviam sido consultados em relação ao contrato com a Nike, e do então presidente da Federação Pernambucana de Futebol, que dizia que não havia controle sobre as atividades da $\mathrm{CBF}$ e que, se alguma filiada tentasse fiscalizar, teria de enfrentar retaliações. A ameaça de ficar fora da disputa dos campeonatos contribuía para que as entidades não se rebelassem, pois somente poderia disputar os principais campeonatos nacionais, que eram e são organizados pela $\mathrm{CBF}$, quem fosse registrado na instituição.

Com relação ao contrato com a Nike em si, a análise da CPI apurou que o valor total estabelecido era de 326 milhões de dólares, mais previsão de pagamento de 43 milhões de dólares por prorrogação de contrato por mais quatro anos, alcançando o total de 369 milhões de dólares para 14 anos de contrato. Nos primeiros dez anos, somente seriam destinados para a entidade 160 milhões desse valor. O relatório da comissão mostra que 150 milhões eram destinados a atividades relacionadas a 
marketing, como publicidade, divulgação, promoção e exposição da seleção pelo mundo, e que esse valor era aplicado seguindo apenas a vontade da fornecedora, que se limitava a comunicar à CBF onde dinheiro foi gasto e investido. A CPI questionou, ainda, que os contratos feririam a legislação esportiva, porque mantinha o resultado esportivo vinculado a interesses comerciais e de marketing, ao contrário da valorização de resultados esportivos voltados para a educação, cidadania e eficiência, que eram previstos na lei Pelé.

Outra irregularidade encontrada foi a não indicação do local onde foi firmado o contrato. A justificativa de Ricardo Teixeira para tanto foi de que a assinatura ocorreu em Nova York, onde não seria necessário indicar o local da assinatura. Além de não constar o local no contrato, este também não apresentava assinaturas de testemunhas, firmas reconhecidas e registro de órgãos competentes.

O relatório da CPI aponta que a ingerência da Nike na CBF tomava proporções elevadas, expressas em cláusulas como a que garantia atuação da empresa “em todas as atividades da CBF". ${ }^{82}$ A multinacional ainda se eximia da responsabilidade de possíveis acidentes ou danos sofridos por atletas da seleção em decorrência do uso de seus produtos. E ia além na sua participação nos negócios do time brasileiro, se tornando a responsável por organizar os jogos e pela escolha dos adversários para os jogos. E mais, tornava obrigatória a presença de ao menos oito dos considerados principais jogadores do time titular em tais partidas.

No que diz respeito à relação com a legislação brasileira, a Nike colocava uma cláusula no contrato que a dava o direito de terminar o contrato de forma unilateral, em caso de situações como uma redução dos valores e benefícios cedidos à empresa, provocada por efeito de algum regulamento, decisão judicial ou lei. A CPI destacou que a Nike cometia um crime previsto pela lei 8137/1990, na medida que se dava ao direito de cancelar o contrato na ocasião de recebimento de alguma notificação de autoridades fiscais para retenção de impostos relativos a pagamentos previstos no contrato com a CBF. O argumento do representante da Nike depoente na CPI, Ingo Ostrovsky, era de que não se deixaria de cumprir decisões judiciais ou fiscais, mas

\footnotetext{
${ }^{82}$ Câmara dos Deputados. Comissão Parlamentar de Inquérito Destinada a Apurar a Regularidade do Contrato Celebrado entre a CBF e a Nike. Brasília, junho de 2001. pp. 74.
} 
que, caso qualquer uma delas que resultasse em diminuição dos direitos adquiridos da $\mathrm{CBF}$, o resultado seria a rescisão do contrato.

Foi discutido também o ponto da participação da empresa Traffic no contrato entre CBF e Nike. A princípio, a empresa de J. Hawilla era apenas uma intermediária entre a entidade e a multinacional norte-americana. No entanto, a comissão apurou que a Traffic era parte do acordo, sendo titular de marcas registradas e direitos de propriedade da CBF. Como a Nike queria obter tais direitos da entidade, a Traffic teria de fazer parte do contrato, o que foi confirmado no depoimento de um representante da Nike na CPI.

Saltava aos olhos dos membros da comissão o crescimento da empresa após o início da relação com a CBF. Segundo o relatório, em 1989, tratava-se de uma empresa modesta e, após onze anos de parceria com a $\mathrm{CBF}$, se tornaria a quinta maior empresa de marketing esportivo do mundo, com faturamento de 262 milhões de dólares no ano de $2000 .{ }^{83}$ Também teve aumento vertiginoso o patrimônio de J. Hawilla, que passou de $\mathrm{R} \$ 3,7$ milhões em 1995 para $\mathrm{R} \$ 76$ milhões, em 1999. Hawilla considerava que o contrato com a CBF ajudou a empresa apenas institucionalmente, e não financeiramente:

"O SR. JOSÉ HAWILLA - Não. Eu confesso que o contrato com a CBF, depois mais amplo, ele foi muito importante pra nossa empresa internacionalmente. Embora financeiramente não tenha sido um bom contrato, um ótimo contrato pra nós, ele institucionalmente foi muito importante, porque a Seleção Brasileira, todos nós sabemos, é famosa no mundo inteiro. É o melhor futebol do mundo, é a que tem mais tradição no mundo inteiro. Então, pra nós, institucionalmente, era muito importante ser a empresa de marketing da CBF. Pra fora do Brasil, isso, pra nós, tinha um valor muito grande e representou muita coisa, embora, repito, não seja... não tenha sido significativa a parte econômica e financeira. " 84

Os direitos adquiridos pela Traffic foram: o de transmissão, em todo mundo, exceto no Brasil, por televisão aberta, dos jogos da seleção nas eliminatórias para a Copa do Mundo de 2002 a serem realizados no Brasil; exclusividade nos direitos de publicidade estática nos estádios; exclusividade para comercialização de transmissões por pay per view para as cidades onde fossem realizados os jogos; direitos de negociação, que acabou abrindo caminho para o rompimento com a Umbro

\footnotetext{
${ }^{83}$ Ibid. pp. 83.

${ }^{84}$ Ibid. pp. 86.
} 
(patrocinadora de material esportivo da seleção antes da Nike). Depois que o negócio com a Nike foi firmado, a Traffic começou a receber 5\% dos US\$16 milhões recebidos anualmente pela CBF. A entidade foi autuada pela Receita Federal por sonegação fiscal, devido à omissão de faturamento, referente aos US\$10 milhões pagos pela Nike diretamente à Umbro, que entraram como receita da CBF.

Com os contratos de patrocínio e de direitos de transmissão, a CBF aumentou sua receita gradativamente, de $\mathrm{R} \$ 18$ milhões em 1997 para $\mathrm{R} \$ 79$ milhões em 2000. Aumentou-se muito o gasto com gratificações, doações, salários e juros. A diretoria que, pelo Estatuto da $\mathrm{CBF}^{85}$, não poderia ser remunerada, passa a ser em 1998.

Dois elementos importantes que o relatório da CPI levanta se destacam, por dar à $\mathrm{CBF}$ um poder político relevante. Em primeiro lugar, a relação com as federações filiadas à entidade. Em segundo lugar, a relação com parlamentares. Quanto às federações, grande parte das despesas da confederação era destinada ao que era chamado de "auxílios eventuais", ou "auxílio a federações filiadas". O valor, em 1997, foi de R \$1,6 milhão; em 1998, R \$5 milhões; em 1999, R \$4,1 milhões; e, em 2000, 7,2 milhões. Além disso, taxas e contribuições devidas pelas federações foram renunciadas voluntariamente pela $\mathrm{CBF}$, segundo o próprio Ricardo Teixeira afirmou em seu depoimento à CPI. ${ }^{86}$

A entidade faria tais doações e ato generoso para que as federações não interferissem em decisões tomadas nas votações da Assembleia Geral da CBF, tornando-se apenas corroboradoras das decisões da confederação. Em paralelo à realização de doações para federações e para parlamentares, a CBF montou uma casa em Brasília, a fim de atender congressistas. O relatório da CPI usa o termo "Bancada da CBF" e ressalta que as doações aos políticos seriam ilegais - segundo a Lei 9504/97, art. 24, VII - pela entidade, juridicamente, ser sem fins lucrativos, e por receber recursos do exterior.

A outra ponta do poder político da CBF é externa aos seus domínios e diz respeito a parlamentares. Parte dos valores de doações da entidade se destinava a

\footnotetext{
${ }^{85}$ Art. 13 - Os membros dos poderes e órgãos não serão, de qualquer forma, remunerados pelas funções que exercerem na $C B F$.

${ }^{86}$ Câmara dos Deputados. Comissão Parlamentar de Inquérito Destinada a Apurar a Regularidade do Contrato Celebrado entre a CBF e a Nike. Brasília, junho de 2001. pp. 100.
} 
candidatos a eleições parlamentares e majoritárias. A CPI apresentou uma lista com os candidatos - com os respectivos valores - que receberam doações da CBF para a campanha das eleições de 1998:

\begin{tabular}{|c|c|c|}
\hline Parlamentar & Valor doado (R\$) & Data da doação \\
\hline Antônio Carlos Amorim Jr. & 50.000 & $18 / 9 / 1998$ \\
\hline Antônio Delfim Neto & 5.000 & 21/8/1998 \\
\hline Paulo Cardoso de Almeida & 50.000 & $30 / 9 / 1998$ \\
\hline \multirow[t]{2}{*}{ Antônio Aquino Lopes } & 25.000 & 25/9/1998 \\
\hline & 32.500 & $30 / 10 / 1998^{*}$ \\
\hline \multirow[t]{2}{*}{ Maurício Magalhães } & 25.000 & $11 / 9 / 1998$ \\
\hline & 25.000 & $30 / 9 / 1998$ \\
\hline Carlos Augusto A. Santana & 50.000 & 09/10/1998* \\
\hline \multirow[t]{2}{*}{ Darcísio Paulo Perondi*** } & 50.000 & $11 / 9 / 1998$ \\
\hline & 50.000 & $30 / 9 / 1998$ \\
\hline José Agripino Maia & 50.000 & $11 / 9 / 1998$ \\
\hline $\begin{array}{l}\text { Hugo Napoleão do Rego } \\
\text { Neto }\end{array}$ & 50.000 & $11 / 9 / 1998$ \\
\hline $\begin{array}{l}\text { Arthur Henrique G. } \\
\text { Ferreira }\end{array}$ & 50.000 & $11 / 9 / 1998$ \\
\hline $\begin{array}{l}\text { Eurico Ângelo de O. } \\
\text { Miranda }\end{array}$ & 50.000 & $11 / 9 / 1998$ \\
\hline Ravena Napoleão do Rego & 50.000 & $30 / 11 / 1998 *$ \\
\hline Total & 612.500 & \\
\hline
\end{tabular}

*Doações fora do prazo legal. Fonte: Câmara dos Deputados. Comissão Parlamentar de Inquérito Destinada a Apurar a Regularidade do Contrato Celebrado entre a CBF e a Nike. Brasília, junho de 2001. pp. 159.

**Membros da CPI na Câmara. 
Além de o relatório destacar que a CBF não teria condições legais para realizar tais doações, mostra também que, mesmo que elas fossem permitidas por lei, a lei 9504/97 previa que o limite para doações de uma empresa era de $2 \%$ do faturamento bruto, e estes valores doados pela CBF representavam 2,18\% do faturamento da entidade, configurando mais uma ilegalidade.

As doações se intensificavam nos períodos eleitorais, chegando ao valor de R \$1.885.768,00 no ano de 1998. No ano 2000, novamente ano eleitoral, as doações chegaram, em dezembro, a $\mathrm{R} \$ 2.178 .093,00 .{ }^{87}$ Especificamente para partidos, a CBF doou $\mathrm{R} \$ 100$ mil para o diretório municipal do PFL de Natal, em setembro de 2000. O relatório argumenta que a CBF fazia doações para campanhas políticas através de recursos para a Federação do Rio Grande do Norte. O presidente da Federação de Futebol do Mato Grosso, Carlos Orione, confirmava, em seu depoimento, que era comum a confederação enviar dinheiro às federações para campanhas eleitorais:

"O SR. CARLOS ORIONE - Eu tô entendendo V.Exa. como isso, como fins eleitorais. Para quê fins eleitorais? Eu recebi, eu recebi da CBF, do Dr. Ricardo Teixeira, uma importância de 50 mil reais que eu pedi que era pra mim ajudar alguns candidatos a Deputado estadual, federal, a Governador do Estado."

“O SR. CARLOS ORIONE - Esses 50 mil foi pra eleitorais, não meu nem dele, foi pra fins eleitorais de candidatos ligados ao futebol de Mato Grosso, (...)"88

Eram realizadas doações para campanhas de presidentes de federações, que disputavam prefeituras, como em Sergipe, onde o presidente era prefeito da cidade de Macambira; no Mato Grosso do Sul, onde o prefeito da cidade de Rio Negro era presidente da federação; na Paraíba, onde o marido da presidente da federação era prefeito de Sossego e também já havia sido presidente da federação; e no Piauí, na cidade de Regeneração, que teve como prefeito eleito o então vice-presidente da CBF, Alfredo Nunes.

Em relação às federações de futebol dos Estados, também foi identificada relação entre dirigentes e a política, caso, por exemplo, do Maranhão, que tinha como

\footnotetext{
${ }^{87}$ Câmara dos Deputados. Comissão Parlamentar de Inquérito Destinada a Apurar a Regularidade do Contrato Celebrado entre a CBF e a Nike. Brasília, junho de 2001. pp. 168. ${ }^{88}$ Ibid., pp. 170
} 
presidente da Assembleia Legislativa o presidente do clube Sampaio Correia. Não só relações políticas foram destacadas no relatório, mas também fatos como domínio de grupos familiares em algumas das federações, caso da de Minas Gerais que, conforme o relatório, empregava 27 parentes ${ }^{89}$ do presidente. A análise da situação administrativa das entidades mostrou, ainda, que havia muitas deficiências de gestão, como falta de orçamento, de prestação de contas, balanços, registros contábeis e pagamento de imposto de renda. Também foi constatada falta de transparência, mesmo com os recursos recebidos da CBF. A CPI chegou até a, nesse momento, mencionar a proposta de criar uma lei, com o intuito de democratizar as relações da CBF e dela com as federações, novamente considerando o futebol como um assunto de relevância para a sociedade brasileira, a despeito do fato das entidades serem, juridicamente, organizações privadas.

Por fim, a CPI faz uma série de sugestões em respeito à administração das federações, como encaminhamentos para o Ministério Público realizar investigações, como denúncias de compras de voto de algumas entidades na eleição de Ricardo Teixeira; encaminhamentos para a Receita Federal analisar possíveis sonegações de impostos; e, para praticamente todas as federações, os membros da comissão recomendaram reformas estatuárias para democratizar a política das entidades, e reformas administrativas para que houvesse, segundo eles, melhorias na gestão, aproximando tais gestões a administrações profissionais. Destaca-se a análise sobre a Federação do Rio de Janeiro, que estava há 16 anos sob a presidência de Eduardo Viana, que fazia duras críticas à Lei Pelé, creditando a ela o momento de crise que se achava que vivia na época.

No que diz respeito às relações de trabalho, a CPI abordou a questão do êxodo de muitos jogadores para países da Europa, inserida num contexto de imigração ilegal, que abrangia não somente jogadores de futebol, mas pessoas das mais variadas profissões, que acabavam vivendo em condições subumanas em tais países. Ficou constatada uma rede de falsificação de passaportes, que envolvia clubes, dirigentes, empresários e jogadores. Os clubes fugiriam da reserva de mercado para jogadores extracomunitários no futebol europeu, os empresários lucrariam com as transações e os jogadores com a valorização de seus direitos econômicos. Dirigentes, como da

${ }^{89}$ Ibid., pp. 194. 
Federação Maranhense de Futebol e de dois clubes do estado, Americano de Bacabal e Motoclube de São Luís, e empresários, como Antônio Oliveira (o Careca), Edmar Bernardes, Jimmy Martins, Roberto Gambaster, Juan Figer, José Mario Pavan, Antônio Cassas de Lima, Clóvis Dias e Edino Nazareth Filho (Edinho), participariam do esquema.

Destaca-se, por fim, que figuras famosas no mundo do futebol prestaram depoimento na CPI, como o empresário Juan Figer, que foi questionado sobre transações de jogadores de clubes pequenos do Uruguai (seu país de origem), que receberiam apenas uma pequena porcentagem dos negócios, para clubes brasileiros, além do fato de os valores envolvidos em tais negociações não aparecerem nas declarações de renda de Figer. Também prestaram depoimento Eurico Miranda voluntariamente -, por duas vezes e Kleber Leite, que foi presidente do Flamengo, para comentar a parceria de sua empresa, a Klefer Produções e Promoções Ltda, com a Traffic, e também sua participação para viabilizar o contrato da CBF com a CocaCola. Outra figura bastante conhecida que prestou depoimento foi Wanderley Luxemburgo, que falou de temas como a ingerência da Nike e de empresários nas convocações e escalações da seleção, além de movimentações financeiras de altos valores em sua conta e de um crescimento muito rápido de seu patrimônio, em poucos anos.

Desta CPI nasce o embrião do projeto de lei para a criação do Estatuto do Desporto. É proposto um “Estatuto do Esporte”, baseado nas análises realizadas pelos deputados, ao ouvir depoimentos e escutar especialistas em audiências públicas. Diversos temas foram propostos, como a definição do papel do Estado em relação ao esporte, integrando o dispositivo constitucional; o conceito de clube formador de atleta; a regulamentação sobre patrocínio e o disciplinamento da atuação de agentes e empresários; medidas protecionistas para a formação das categorias de base; a responsabilidade dos dirigentes esportivos; e o detalhamento nas condições contratuais trabalhistas dos agentes desportivos. Os deputados queriam que as entidades, como as federações, os clubes e a CBF prestassem contas à sociedade brasileira, se comprometendo a praticar administrações consideradas responsáveis e modernas, deixando claro o discurso que ia ao encontro da ideia de modernização do esporte. Achavam que uma nova legislação deveria ir além das questões das relações 
de trabalho e do clube-empresa, que foram temas bastante debatidos ao longo da década de 1990, por isso a ideia de um estatuto, para reunir as mais diversas questões, ideia que seria melhor trabalhada nos próximos anos, especialmente a partir do aqui chamado de "período regulagório".

\section{b) CPI do Futebol no Senado}

No Senado, o presidente da CPI era Álvaro Dias (PSDB-PR), Gilberto Mestrinho (PMDB-AM) era o vice-presidente e o relator era Geraldo Althoff (PFLSC). Destaca-se a participação de parlamentares ligados a entidades desportivas, como Maguito Vilela (PMDB-GO), que foi dirigente do clube Jataiense-GO e teve seu nome emprestado à lei que fez alterações na lei Pelé, e Leomar Quintanilha (PMDB-TO). A comissão teve o apoio de órgãos como o Ministério Público, o Ministério da Justiça, o Ministério da Previdência e Assistência Social, o INSS, o COAFI (Conselho de Controle da Atividades Financeiras), a Procuradoria Geral da República, o Banco Central, o Tribunal de Contas da União, a Receita Federal e consultorias legislativas.

Ela é criada no dia 14 de setembro de 2000 e a primeira reunião é realizada no dia 19 de outubro do mesmo ano. Prestaram depoimentos muitos nomes de destaque do meio futebolístico brasileiro, como o ex-jogador Wilson Piazza, o jornalista Juca Kfouri, o técnico Wanderley Luxemburgo, o presidente da Traffic J. Hawilla, o presidente da CBF Ricardo Teixeira, o contador da entidade Aldo Ferreira, o expresidente do Vasco da Gama Agarthyno da Silva Gomes, também o ex-conselheiro fiscal do clube Ivon Bernardo Morgado, o empresário de futebol Juan Figer, o então presidente da Federação Paulista de Futebol Eduardo José Farah, o então presidente da Federação de Futebol do Rio de Janeiro, Eduardo Viana, os ex-presidentes do Flamengo Márcio Braga e Kleber Leite, além do então presidente do clube Edmundo Santos Silva. Foram realizadas audiências públicas envolvendo nomes importantes do futebol, como o ex-jogador Sócrates, o advogado especialista em direito esportivo Marcílio Krieger, o representante do Clube dos 13 João Bosco Luz de Moraes, o jurista Valed Perry, o promotor Fernando Capez, o ex-jogador e então deputado Roberto Dinamite, o advogado especialista em legislação esportiva e ex-presidente do São Paulo Carlos Miguel Aidar, o jornalista Flávio Prado e Pelé. 
O discurso, assim como na Câmara, também era de que o futebol não envolvia somente os interesses das entidades privadas que participavam dele, mas também os interesses da sociedade brasileira, como um todo:

“(...) Embora constituam entidades de direito privado, a CBF, as federações estaduais e os clubes de futebol lidam com elementos de valor que envolvem não apenas o interesse específico dos associados ou das pessoas que integram seus quadros, mas que dizem respeito, igualmente, aos direitos de cidadania de grandes porções da população. Por sua importância para a formação de nossa identidade, o futebol está nitidamente atrelado à cultura do País, integrando, sem dúvida, o patrimônio cultural coletivo." 90

Além disso, também argumentava-se que propostas de mudanças do cenário do futebol brasileiro deveriam ser resultantes da CPI:

“(...) ouso vaticinar que o futebol brasileiro não será o mesmo após esta CPI. Nada terá valido a pena se não sairmos deste inquérito legislativo com a cultura que envolve o futebol realmente transformada e a consciência da sociedade brasileira sobre o universo que o cerca realmente amadurecida. Essa a contribuição que a CPI do Futebol espera estar legando ao País. Que o panorama desvelado no curso das investigações e os mecanismos legais indicados para a correção dos desvios proporcionem o pleno desenvolvimento do futebol brasileiro como atividade desportiva social e economicamente relevante. Esse o nosso desejo, essa a nossa esperança." 91

O relator acreditava que uma CPI poderia resultar numa nova proposição legislativa e que o papel dos parlamentares envolvia até mesmo poderes de autoridades judiciais, não para julgar ou estabelecer penas, mas para realizar diligências, requisitar documentos de órgãos públicos, convocar ministros de Estado, tomar depoimentos de autoridades, inquirir testemunhas, ouvir indiciados, solicitar quebras de sigilo bancário, requerer ao Tribunal de Contas da União realização de inspeções e auditorias e, seu papel fundamental, informar.

\footnotetext{
${ }^{90}$ Senado Federal. Relatório Final da Comissão Parlamentar de Inquérito. Criada por meio do Requerimento $n$. 497, de 2000-SF, "destinada a investigar fatos envolvendo as associações brasileiras de futebol”. Brasília, 2001. Volume I. pp. 5

${ }^{91}$ Geraldo Althoff, relator da CPI. Em: Senado Federal. Relatório Final da Comissão Parlamentar de Inquérito. Criada por meio do Requerimento n. 497, de 2000-SF, "destinada a investigar fatos envolvendo as associações brasileiras de futebol”. Brasília, 2001. Volume I. pp. 31
} 
Assim como na Câmara, temas como a administração de entidades como clubes, federações e CBF, doações eleitorais da CBF, o patrimônio de seu então presidente, a atuação de empresários do futebol, o patrimônio de Wanderley Luxemburgo, etc, também foram alvo dos trabalhos dos senadores. Também se considerava que as entidades procuravam levar ao extremo o argumento de que tinham caráter privado, sem fins lucrativos, portanto, não deveriam maiores explicações ao público em geral, desconsiderando que isso não lhes dava o direito de fazer o que bem entendessem, como deixar de recolher à Previdência Social a contribuição de 5\% da receita bruta vinda dos jogos em território nacional, e de 5\% sobre os contratos de patrocínio, licenciamento de uso de marcas e símbolos, publicidade, propaganda e transmissão dos jogos, bem como deixar de recolher contribuição sobre o desconto efetuado de seus atletas e demais empregados, inclusive décimo terceiro salário.

Contrário à instalação da CPI, Eurico Miranda tentou evitar que ela existisse, cometendo, segundo o relatório, "manobras diversionistas e de intimidação aos trabalhos da CPI"92, o que resultou na abertura de algumas representações contra o então deputado, por parte da comissão. $\mathrm{O}$ documento afirma que o então deputado fazia declarações ofensivas aos membros da comissão, recusava-se a prestar esclarecimentos e a apresentar documentos quando solicitado, e ameaçava assessores da CPI. O trecho de uma matéria do Jornal de Brasília é utilizado para confirmar tal ameaça:

“A um grupo de jornalistas, na quarta-feira, o deputado Eurico Miranda destilou seu ódio contra um assessor da CPI do Futebol, do Senado, dizendo, inclusive, que não vai àquela comissão "para não dar uma porrada nele"”, (grifo nosso). ${ }^{93}$

A despeito de tal resistência de Miranda, a CPI avançou e abordou um tema que dizia respeito, inclusive, ao clube do então deputado, o Vasco da Gama. O assunto era a relação entre entidades desportivas e empresas privadas. Em 1997, o Banco Excel-Econômico associou-se aos clubes de futebol do Corinthians e do Vitória (BA), realizando contratos de $\mathrm{R} \$ 5$ milhões com o clube paulista e $\mathrm{R} \$ 2$ milhões com o clube baiano, por ano. Já em 1998, o Vasco firma uma parceria com o

\footnotetext{
${ }^{92}$ Senado Federal. Relatório Final da Comissão Parlamentar de Inquérito. Criada por meio do Requerimento $n$. 497, de 2000-SF, "destinada a investigar fatos envolvendo as associações brasileiras de futebol”. Brasília, 2001. Volume I. pp. 46.

${ }^{93}$ Ibid. apud. Jornal de Brasília, 23 de março de 2001.
} 
Nations Bank/Banco Liberal, em que o banco exploraria todos os contratos de marketing, lincenciamento e direitos de imagem do clube, sendo criada uma empresa especialmente para tal operação, denominada Vasco Lic.; ainda em 1998, o Banco Opportunity comprou $51 \%$ das ações do Bahia (que se tornava Bahia S.A.).

O relatório ressalta que essas empresas passaram, após certo tempo, a se tornarem investidores no mercado do futebol brasileiro e não apenas patrocinadores. A ideia era dividir os lucros do negócio. As empresas que mais se destacaram nessas experiências, foram a Hicks Muse Tate \& Furst e a International Sports Leisure (ISL), a qual acabava de entrar em processo de falência. Depois do término da experiência com o Banco Excel, o Corinthians passou a se relacionar com a Hicks Muse, que assumia o departamento de futebol do clube por dez anos, num contrato de $\mathrm{R} \$ 53$ milhões mais a construção de um estádio multiuso que, como o tempo mostrou, não foi tirado do papel. O grupo também realizou parcerias com o Cruzeiro. Já a ISL, antes de falir, explorou a marca do Flamengo, bastante valorizada no futebol nacional, fechando um contrato que chegava a R \$137 milhões, incluindo também a construção de um estádio, para 60 mil torcedores, e que também não saiu do papel. A empresa ainda fechou contratos com o Grêmio.

Com o tempo, as parcerias foram se desfazendo, e os clubes continuavam a ter de lidar com problemas administrativos, tributários e dívidas. O senador Álvaro Dias (PSDB-PR) informava que a Receita Federal já havia multado jogadores, técnicos e clubes por sonegação fiscal em valores que, somados, chegavam a $\mathrm{R} \$ 100$ milhões, envolvendo desconto de Imposto de Renda sobre salários em valores inferiores aos necessários, entrada de produtos estrangeiros no país sem pagamento do imposto devido e sonegação em operações de compra e venda de jogadores ${ }^{94}$.

Alguns parlamentares queriam que saísse uma lei após a CPI do Futebol, no Senado, envolvendo a responsabilidade administrativa para os dirigentes de clubes e uma lei de responsabilidade para infratores. Álvaro Dias queria uma medida provisória, para evitar influência da bancada ligada aos clubes, na Câmara dos Deputados. Senadores da CPI tinham algumas propostas para uma nova legislação, como a proposta de Maguito Vilela, que sugeria colocar o TCU para fiscalizar a CBF;

\footnotetext{
${ }^{94}$ CPI já tem papel que liga futebol a paraíso fiscal. Folha de São Paulo, Esportes, 12 de outubro de 2000.
} 
os senadores ainda queriam limitar os mandatos dos dirigentes de clubes, com apenas uma reeleição permitida e, por fim, evitar que os dirigentes gastassem mais do que recebiam, para não permitir que deixassem dívidas para as futuras administrações, medida considerada como uma Lei de Responsabilidade Fiscal para o esporte ${ }^{95}$.

As duas CPIs abordaram muitos assuntos relativos ao futebol brasileiro, em especial temas relacionados à administração de entidades desportivas, fazendo uma análise detalhada da situação financeira e administrativa de clubes, federações e da $\mathrm{CBF}$, investigando seus dirigentes, ações destes em relação a atletas, notadamente no que diz respeito às relações trabalhistas. As discussões no Congresso inspiraram ideias para mudanças na administração das entidades e em aspectos do futebol, em geral, no país, destacando-se o que se tornaria, mais à frente, uma proposta de legislação, o Estatuto do Desporto. Os trabalhos da CPI mostraram que, em diversos momentos decisivos de possíveis alterações na estrutura vigente do esporte no Brasil, grupos interessados em tais questões se manifestaram e procuraram agir para barrar ou para incentivar mudanças. A própria CPI foi alvo da ação dos grupos, tanto para apoio às investigações, no caso de alguns atletas, ex-atletas, jornalistas e alguns dirigentes, quanto para oposição a elas, no caso de alguns clubes, federações e seus dirigentes, como Eurico Miranda, e CBF, representada por Ricardo Teixeira.

\section{2) Período Regulatório}

No período aqui chamado de "regulatório", as interferências do governo passam a ser maiores. O período anterior, denominado "liberal", foi marcado por muitas ações por parte do governo, como a criação de uma secretaria de esportes no governo Collor, a formação de um ministério extraordinário para os esportes no governo Fernando Henrique Cardoso, e a preocupação de ambos em alterar o status jurídico do esporte e, especificamente, do futebol no país. No entanto, tais ações se deram com o intuito de liberalizar o esporte. Extinguir a lei do passe siginificava colocar os jogadores de futebol na esfera do trabalhador comum, que é livre para decidir como administrar sua carreira, pode procurar um local de trabalho diferente quando não está satisfeito, ou quando recebe uma proposta de trabalho melhor em relação ao seu emprego no momento. Esse tipo de liberdade, acreditavam esses

\footnotetext{
${ }^{95}$ Senado quer ajuda de FHC para editar nova MP do esporte. Folha de São Paulo, Esportes, 27 de novembro de 2000.
} 
governos, não era possível com o passe, que prendia os atletas. O governo agiu, portanto, assim como o poder legislativo, para que se pudesse ter mais liberdade de ação dentro do futebol. O mesmo se passou em relação à administração dos clubes, área em que se tentou equiparar a situação jurídica das entidades a de empresas. Porém, não se criou uma política em si para o esporte.

Já no período a ser estudado agora, as ações governamentais, adotadas pela administração Lula e, posteriormente, Dilma Rousseff, serão mais diretas. Existirão políticas criadas pelo próprio governo para as diretrizes que o esporte seguirá no país. Quanto aos temas específicos que dizem respeito à modernização do futebol brasileiro, uma série de medidas será proposta para regular a questão administrativa dos clubes, envolvendo a forma como os dirigentes lidam com a gestão do futebol, bem como a maneira como respondem ao governo sobre suas ações, especialmente no que diz respeito ao pagamento de impostos. Sobre as relações de trabalho, a lei Pelé e a lei Maguito Vilela acabaram, de certa maneira, consolidando a questão. Porém, alguns pontos ainda ficaram soltos e também foram alvo de discussão no período.

\subsection{1) Estatuto do Desporto e Projeto de Lei 5186/05}

Esta seção reconstituirá o debate em torno dos projetos do Estatuto do Desporto, do Projeto de Lei 5186/05 e, com menor ênfase, do Estatuto do Torcedor. Não se desconsidera a importância deste último, no entanto ele não teve como foco as principais questões abordadas aqui. Não entrou na questão do passe e, quanto à administração dos clubes propôs sanções a entidades esportivas que não prestassem contas e colocou a oportunidade de renegociação de dívidas com o governo. Essas questões não foram essenciais ao projeto, que tinha como objetivo principal garantir direitos aos torcedores de futebol, especialmente aqueles relacionados aos direitos destes como consumidores, o que não deixa de ser uma face da modernização do futebol, mas que não será abordada nesta dissertação.

As principais propostas do Estatuto eram: criar uma lei do esporte de maneira geral, não apenas do futebol; a obrigação dos clubes apresentarem balanços; a limitação de mandatos de dirigentes a dois anos; durante a tramitação do projeto, clubes tentaram trazer o passe de volta, sem sucesso. Foram apresentadas 123 emendas, sendo 71 elaboradas pelo Clube do 13 e houve muitos debates e seminários 
na Câmara. A votação foi adiada por várias vezes. O ponto da limitação dos mandatos foi retirado pelo relator do projeto, depois de pressão dos dirigentes da CBF. Além disso, os clubes que possuíssem departamentos profissionais deveriam criar departamentos financeiros, com contabilidade.

Quanto ao projeto de lei 5186/05, de origem do poder executivo, os objetivos principais eram dar tratamento especial ao futebol; a definição de novas regras de relacionamento profissional entre atletas e entidades desportivas; e o aumento no repasse de recursos para os clubes formadores de atletas, tanto das modalidades olímpicas quanto do futebol. Ele passa por análise de uma comissão especial na Câmara e passa a tramitar em regime de urgência urgentíssima. Em 2008, outra comissão é criada para analisar o projeto, da qual participam dirigentes de futebol, exatletas, empresários e jornalistas. O parecer do relator da comissão que foi aprovado trazia os seguintes pontos: estabelecimento de uma cota de 5\% para os clubes formadores, em relação aos valores de transferências nacionais de jogadores. Para aqueles que contribuíram com a formação dos atletas dos 14 aos 17 anos, a cota seria de $1 \%$ do total da negociação, para cada ano de investimento no jogador. Para os que investiram na formação entre 18 e 19 anos, uma cota de 0,5\% do valor da transferência; possibilidade de assinar contratos aqueles atletas que possuíssem 16 anos ou mais; impedimento de ações judiciais de dívidas das entidades serem executadas, caso a cobrança comprometesse o funcionamento dos clubes; indenizações para atletas e clubes nas transferências; e restrição a ação de empresários.

O novo governo, do PT, tinha um projeto para uma nova lei, o Estatuto do Desporto, mas que também previa punições para a não publicação de balanços e outras irregularidades por parte dos dirigentes de clubes, que poderiam ficar afastados por até oito anos. Isso apesar da esperança de alguns dirigentes de que o governo do PT não fosse tão rigoroso com a fiscalização dos clubes, o que era negado pelo futuro ministro, Agnelo Queiroz ${ }^{96}$. O novo ministro era um entusiasta dos esportes de alto rendimento, mas tinha como meta voltar as atenções para os projetos sociais do

\footnotetext{
${ }^{96}$ Lei preferida pelo PT também prevê punições. Folha de São Paulo, Esportes, 27 de dezembro de 2002.
} 
esporte. Mostrava ${ }^{97}$ também alguns pontos de concordância com o presidente da CBF, Ricardo Teixeira, no sentido de acreditar que não deveria intervir na entidade e em outras confederações, por se tratarem de patrimônios privados.

No ano de 2003, entraria em vigor, sancionado pelo presidente Lula, o Estatuto de Defesa do Torcedor. As regras colocadas pelas novas medidas incluíam a vigilância do Ministério Público sobre a segurança nos estádios e o afastamento de dirigentes que não prestassem contas da situação financeira dos clubes. $\mathrm{O}$ estatuto deveria induzir clubes e entidades a se tornarem empresas com a promessa de incentivos, como acesso ao Refis, programa de refinanciamento de dívidas com a Receita $^{98}$, do qual a Federação Paulista de Futebol participou, para pagar pagar ${ }^{99} \mathrm{R} \$ 5$ milhões em impostos atrasados para o governo, bem como a empresa de Pelé ${ }^{100}$, a Pelé Sports \& Marketing Ltda, que devia R $\$ 2,2$ bilhões em impostos, não recolhidos entre 1992 e 1999, além do técnico Wanderley Luxemburgo ${ }^{101}$ e Luiz Estevão, o primeiro autuado pela Receita Federal em $\mathrm{R} \$ 1,3$ milhão, após não saber explicar, na CPI do Futebol, depósitos não declarados em torno de R \$10 milhões em suas contas, e o segundo, fundador do Brasiliense Futebol Clube e ex-senador, que tinha dívidas relativas às suas empresas. Clubes também aderiram ao Refis, como o Flamengo, que

${ }^{97}$ CBF ganha salvaguarda do novo ministro do Esporte. Folha de São Paulo, Esportes, 24 de dezembro de 2002.

98 “O Programa de Recuperação Fiscal foi instituído pela Medida Provisória n ${ }^{\circ}$ 1.923, de 6 de outubro de 1999, posteriormente convertida na Lei ${ }^{\circ}$ 9.964, de 10 de abril de 2000. Este diploma legal estabeleceu duas modalidades de parcelamento unificado dos débitos de responsabilidade de pessoas jurídicas, vencidos até 29 de fevereiro de 2000 e relativos a tributos administrados pela Secretaria da Receita Federal do Brasil (RFB) e, na época, pelo Instituto Nacional do Seguro Social (INSS). No art. $2^{\circ}$ desta Lei, foi criado parcelamento sem prazo definido cujas parcelas são calculadas com base na receita do devedor. Alternativamente a este parcelamento foi definido no art. 12 da Lei $\mathrm{n}^{\circ}$ 9.964, de 2000, parcelamento em 60 parcelas iguais e sucessivas.

A opção pelo Programa de Recuperação Fiscal aberta com a edição da Medida Provisória ${ }^{\circ}$ 1.923, de 1999, encerrou-se no ultimo dia útil de abril de 2000. Posteriormente, a Lei $\mathrm{n}^{\circ}$ 10.002, de 14 de setembro de 2000, reabriu o prazo para adesão a este programa até o dia 13 de dezembro de 2000.)" Fonte: http://www.pgfn.fazenda.gov.br/divida-ativa-da-uniao/todosos-servicos/informacoes-e-servicos-para-pessoa-fisica/copy_of_parcelamentos/refis

${ }^{99}$ Painel FC, Folha de São Paulo, 28 de outubro de 2003.

${ }^{100}$ Painel FC, Folha de São Paulo, 10 de novembro de 2003.

${ }^{101}$ Receita autua em R\$4mi a gestão de Farah na FPF. Folha de São Paulo, Esportes, 12 de novembro de 2003. 
possuía dívidas de $\mathrm{R} \$ 26$ milhões, o Fluminense, que acabou excluído do programa, por falta de pagamento, o Atlético Mineiro e o Palmeiras, que gastaria quase $\mathrm{R} \$ 6$ milhões com o parcelamento de suas dívidas.

A medida provisória número 39 foi rejeitada no plenário da Câmara e foi aprovado, em comissão especial, e encaminhado para votação em plenário, o projeto de lei 4874/2001, que instituiria o Estatuto do Desporto, que seria a estrutura da política para os esportes do governo Lula. O Partido dos Trabalhadores achava que o governo FHC havia priorizado o futebol, em detrimento dos outros esportes e da educação esportiva, voltada para o desenvolvimento social. Gilmar Machado, deputado pela sigla e relator do projeto do estatuto, afirmou que o PT achava que "futebol é esporte, não que esporte é futebol, como fez $\mathrm{FHC}^{102} \mathrm{em}$ seu governo" 103 , que o governo não deveria entrar nas disputas dos clubes de futebol, e que empresas públicas poderiam patrocinar times de futebol, mas também deveriam financiar projetos sociais.

Por outro lado, o deputado do mesmo partido, Dr. Rosinha, achava que não seria possível conciliar financiamentos a projetos sociais com a utilização de recursos vindos dos bingos. Essa prática deveria ser afastada do universo dos esportes, segundo o deputado. Machado considerava ${ }^{104}$ que a utilização do dinheiro dos bingos poderia ser discutida e revista. Já Eurico Miranda, que não havia conseguido se reeleger para a Câmara, era a favor ${ }^{105}$ do uso de tais recursos, bem como dos financiamentos das empresas públicas para projetos sociais, e ainda do Estatuto em si, que considerava que teve a discussão apropriada no Congresso, durante seis meses.

Em 2003, o projeto foi encaminhado a uma comissão do Ministério do Esporte, que sugeriria emendas e alterações ao documento. Tal comissão seria coordenada pela assessora especial Virgínia Mesquita, que havia colaborado com a Comissão de Educação, Cultura e Desporto da Câmara dos Deputados. Os deputados

\footnotetext{
${ }^{102}$ Governo que havia investido, em seu segundo mandato, $\mathrm{R} \$ 421,3$ milhões, valor baixo, comparado às outras áreas, por exemplo, os gastos com passagens aéreas e diárias, que, somente no ano de 2002, giraram em torno de R\$690 milhões. Folha de São Paulo, Painel FC, 04 de dezembro de 2002.

${ }^{103}$ PT fala em vetar mais uma vez MP e já aprova estatuto. Folha de São Paulo, Esportes, 07 de novembro de 2002.

${ }^{104}$ Painel FC, Folha de São Paulo, 09 de novembro de 2002.

${ }^{105}$ Eurico Miranda dá apoio ao documento. Folha de São Paulo, Esportes, 08 de novembro de 2002.
} 
petistas mais otimistas em relação ao andamento do projeto acreditavam que ele seria votado até o mês de abril, enquanto os outros consideravam que o tempo seria de seis meses, após passar por debates, alterações e tramitação ${ }^{106}$.

Em paralelo ao andamento do projeto do Estatuto do Torcedor, corria, em regime de urgência, a tramitação do projeto de lei número 7262/03, enviado ao Congresso na gestão FHC, denominado Código de Defesa do Torcedor, renomeado pelo Ministério do Esporte para Estatuto de Defesa do Torcedor, em relação ao qual o PT pretendia tirar o caráter de urgência e incorporá-lo ao debate do Estatuto do Desporto $^{107}$, projeto considerado ideal pelo partido. Mas o governo aceitava 108 aprovar o Estatuto de Defesa do Torcedor, principalmente porque este projeto equiparava o torcedor ao consumidor comum.

O projeto previa multas e destituição para dirigentes, em caso de falhas na transparência de suas finanças, como na divulgação de seus balanços nos prazos corretos. Alguns dirigentes, como Marcelo Portugal Gouvêa, então presidente do São Paulo, pediam mais tempo para tais divulgações. Dirigentes criticavam também o que eles consideravam exageradas alterações nas leis, dentre elas, uma recente, que estava inserida em mudanças ocorridas no Código Civil, em 2002, e dizia respeito à estrutura das associações esportivas, especificamente com relação aos seus processos eleitorais, no sentido de não mais manter dirigentes em mandatos muito longos, como acontecera com Mustafá Contursi (Palmeiras) e Alberto Dualib (Corinthians). A escolha dos novos dirigentes ficaria a cargo de uma assembleia geral dos sócios e não de um conselho fechado, como era até então. Os clubes, mais uma vez, alegavam que a Constituição de 1988 garantia autonomia a eles para decidirem sobre seus processos eleitorais $^{109}$.

O ponto da equiparação do torcedor ao consumidor comum foi aprovado e contribuiu para a modernização do futebol brasileiro, pois permitia que o torcedor

\footnotetext{
${ }^{106}$ Painel FC, Folha de São Paulo, 28 de janeiro de 2003.

${ }^{107}$ Painel FC, Folha de São Paulo, 07 de fevereiro de 2003.

${ }^{108}$ Esporte vira "bola da vez" no Congresso. Folha de São Paulo, Esportes, 17 de fevereiro de 2003.

${ }^{109}$ Dirigentes fazem críticas e pedem mudanças. Folha de São Paulo, Esportes, 17 de fevereiro de 2003.
} 
pudesse pedir indenização ${ }^{110}$ por danos materiais e morais em situações como não conseguir sentar no lugar marcado em seu ingresso, não encontrar sanitários considerados adequados em quantidade e limpeza, pagar preços abusivos por alimentos no interior dos estádios, e passar por alguma situação de briga em seus territórios, o que poderia resultar na paralisação de uma competição, por meio de pedido do torcedor.

Já o projeto do Estatuto do Desporto receberia uma série de cortes, acertados por Agnelo Queiroz e a bancada do PT na Câmara. Os pontos mais polêmicos seriam retirados, mas trazidos novamente no momento da regulamentação do projeto pelo Ministério do Esporte. O objetivo era votar o texto até o final de maio - previsão posteriormente adiada para junho ${ }^{111}$-, unificando a legislação esportiva, pela incorporação da MP79 e do Estatuto de Defesa do Torcedor ${ }^{112}$. Seria introduzido um ponto que daria incentivos fiscais a empresas que investissem em esportes.

Lideranças de dirigentes do futebol brasileiro planejavam ${ }^{113}$ ida à Brasília, com o objetivo de participar ativamente da elaboração do Estatuto do Desporto, alegando que já tinham ficado de fora da lei do torcedor. Em agosto, o projeto ainda não havia sido votado e a participação destes dirigentes - de clubes, federações e da CBF - se intensificou. O presidente interino da CBF, Nabil Abi Chedid ${ }^{114}$, no evento da reeleição do então presidente da Federação de Futebol do Estado do Rio de Janeiro, Eduardo Viana, discursou contra o fim da lei do passe, com o apoio de Viana, alegando que os clubes estavam tendo prejuízos e deixando de formar jogadores, e pediu para que o mecanismo fosse trazido de volta pelo Estatuto do Desporto:

\section{“(...)Temos que nos unir para derrubar o fim do passe livre no Estatuto do Desporto." $" 115$}

Além disso, o novo presidente da Federação Paulista de Futebol, Marco Polo del Nero, teria pedido, em visita à cidade de Ribeirão Preto, ao então prefeito Gilberto

\footnotetext{
${ }^{110}$ Torcedor ganha status de consumidor. Folha de São Paulo, Esportes, 20 de fevereiro de 2003.

${ }^{111}$ Senado remarca para hoje votação da MP 79. Folha de São Paulo, Esportes, 02 de abril de 2003.

112 Painel FC, Folha de São Paulo, 23 de fevereiro de 2003.

${ }^{113}$ Painel FC, Folha de São Paulo, 18 de abril de 2003.

${ }^{114}$ Já havia sido presidente do Clube Atlético Bragantino e da Federação Paulista de Futebol.

${ }^{115}$ CBF começa ofensiva pela volta do passe. Folha de São Paulo, 01 de agosto de 2003.
} 
Magioni, do Partido dos Trabalhadores - partido do governo -, ajuda política para que o passe fosse ressuscitado no Estatuto do Desporto, conforme noticiava a Folha de São Paulo ${ }^{116}$. Foram organizados, pelo deputado Gilmar Machado, cinco seminários para discutir o estatuto ${ }^{117}$, envolvendo atletas e dirigentes, antes de o projeto entrar em votação na Câmara. Seria candidato a presidir a comissão especial que seria instalada na Câmara para analisar o projeto o deputado Deley (PV-RJ), apadrinhado por Machado. As notícias ${ }^{118}$ davam conta de que o projeto tinha poucas chances de ser aprovado ainda em 2003 e a CBF sugeria a Gilmar Machado a proibição ${ }^{119}$ de transferências de jogadores com o campeonato brasileiro em andamento, e que houvesse a criação de janelas de negociações, abertas após o término do torneio.

O Clube dos 13, com ajuda da CBF e da FGV, tentou aprovar 30 emendas ${ }^{120}$ ao Estatuto. Dezesseis emendas foram entregues por deputados que concordavam com as ideias da entidade. Queriam evitar que os dirigentes fossem responsabilizados por más administrações. Na primeira tentativa, mandaram as emendas para o Ministério do Esporte, que passou para o deputado Marcelo Ortiz (PV-SP), mas ele mandou em nome das entidades e só deputados poderiam apresentar emendas. Ele foi criticado e retirou as emendas. Depois, mandaram diretamente para o relator, que engavetou as propostas. Mandaram ainda por Marcelo Guimarães Filho (PFL-BA), filho do então presidente do Esporte Clube Bahia, que enviou as que considerou mais importantes, como as que propunham limitar a ação dos empresários no futebol e manter a autonomia das entidades esportivas.

Antônio Roque Citadini, então vice-presidente de futebol do Corinthians, escreveu dez propostas a serem enviadas para os deputados introduzirem como emendas ao projeto e reclamava que os clubes seriam exageradamente taxados:

"É taxa e mais taxa para a gente, 20\% de direito de arena, $1 \%$ para Justiça esportiva, $5 \%$ de tudo o que o clube arrecada para o Fundo de Desenvolvimento do Esporte. Até ex-atletas querem que os clubes sustentem." 121

\footnotetext{
${ }^{116}$ Painel FC, Folha de São Paulo, 27 de agosto de 2003.

117 Painel FC, Folha de São Paulo, 10 de setembro de 2003.

${ }^{118}$ Painel FC, Folha de São Paulo 03 de outubro de 2003.

119 Painel FC, Folha de São Paulo, 07 de dezembro de 2003.

${ }^{120}$ Clubes jogam cartada final em estatuto. Folha de São Paulo, 10 de dezembro de 2003.

${ }^{121}$ Futebol age contra olímpicos na Câmara. Folha de São Paulo, 11 de dezembro de 2003.
} 
No final das contas, foram apresentadas 123 emendas ao projeto, das quais o Clube dos 13 reivindicava autoria de 71, com o apoio da CBF, da Federação Paulista de Futebol e da FGV. A imprensa afirmava que o Clube dos 13 queria formar uma nova bancada da bola, que teria como objetivo defender as 71 emendas criadas pela entidade, que preparava uma cartilha ${ }^{122}$ com os problemas do futebol brasileiro, a ser entregue aos deputados em fevereiro, quando a matéria voltaria a ser discutida. Quanto a outras emendas, uma apresentada por Bismarck Maia (PSDB-CE) desagradava dirigentes de futebol, pois previa a limitação de seus mandatos, que não poderiam permanecer no poder por mais de oito anos - o que equivaleria a uma reeleição. Por outro lado, o mesmo deputado apresentou outra emenda, que dava ao Comitê Olímpico Brasileiro o status de entidade nacional de administração do desporto, o que faria com que a instituição passasse a ser alvo de fiscalizações pelas quais os clubes de futebol também passariam o que agradou a estes. As notícias, agora, davam conta de que o projeto só deveria ser votado em maio de $2004^{123}$, apesar de Gilmar Machado pretender levar para votação em abril, pois em maio começaria a se preparar para a disputa da prefeitura da cidade de Uberlândia ${ }^{124}$. Em junho, o projeto ainda não havia sido votado e representantes da CBF e do Clube dos 13 acreditavam que a votação não aconteceria em 2004. O diretor jurídico da entidade dos grandes clubes, Celso Rodrigues, apostava que não seria votada a matéria nem em 2005.

A comissão que analisaria o projeto era composta por quatro parlamentares do PMDB, quatro do PSDB, cinco do PFL e seis do PT, que contava também com o relator, e se empenhava em conseguir que o PMDB, seu aliado, ficasse com a presidência, mas a chance maior ${ }^{125}$ era que tal posto fosse designado ao PFL.

Em setembro, alguns resultados da pressão exercida por dirigentes da CBF e do Comitê Olímpico Brasileiro sobre o Congresso e o governo começavam a surgir. O relator, Machado, resolveu tirar do texto o ponto que limitava a dois os mandatos de presidentes das entidades de administração do esporte:

\section{"Resolvemos tirar para amenizar a pressão dos dirigentes. Voltaremos a}

\footnotetext{
${ }^{122}$ Painel FC, Folha de São Paulo, 29 de dezembro de 2003.

${ }^{123}$ Painel FC, Folha de São Paulo, 12 de dezembro de 2003.

${ }^{124}$ Painel FC, Folha de São Paulo, 11 de janeiro de 2004.

${ }^{125}$ Painel FC, Folha de São Paulo, 04 de janeiro de 2004.
} 
discutir o assunto nos simpósios que serão realizados. Se os parlamentares acharem que é o caso de haver limitação, o item voltará"126

No entanto, o relator não disse quem teria cedido às pressões e nem o motivo para tal. A Folha de São Paulo afirmava que a pressão teria atingido ${ }^{127}$ também o $^{2}$ ministro do Esporte, Agnelo Queiroz, e o ministro da Coordenação Política, Aldo Rebelo. Queiroz se dizia a favor da limitação dos mandatos, mas críticos ao ministro diziam que ele não contrariaria Carlos Artur Nuzman, presidente do COB, que tivera todas as suas reivindicações atendidas pelo ministério. Por outro lado, Rebelo se mostrava a favor da limitação, elemento que estava presente no relatório da CPI, o qual destacava a necessidade da alternância no poder nas entidades, e representava uma ameaça aos dirigentes, devido à sua força dentro do governo.

Entidades esportivas seguiam demonstrando interesse na matéria e promovendo discussões sobre o tema, a fim de chegar a conclusões a respeito dele e defender seus interesses. A Federação Paulista de Futebol patrocinava um evento na Câmara dos Deputados, coordenado pela deputada Mariângela Duarte (PT-SP), que buscou a federação, para discutir o que poderia ser a nova lei do esporte nacional. A entidade, assim como outras federações, continuava batalhando para manter o que chamava de autonomia garantida pela constituição federal, assim como para evitar que tivesse muitos encargos, como trabalhistas e fiscais, além de tentar garantir financiamentos com o governo. Era noticiado que a ligação ${ }^{128}$ entre a deputada e a federação se dava por intermédio do então vice-presidente da entidade e diretor do porto de Santos - que seria a base eleitoral de Duarte -, Mauro Marques. A parlamentar e o presidente da federação, Marco Polo del Nero, não entendiam o patrocínio como conflito de interesses, alegando que o evento ouviria todas as partes interessadas.

Nesse evento, em São Paulo, o governo, por meio do então secretário executivo do Ministério do Esporte, Orlando Silva, anunciou que tinha planos de criar algo na legislação especialmente para o futebol, conforme pediam alguns dirigentes

\footnotetext{
${ }^{126}$ Após lobby, limitação de mandato some de estatuto. Folha de São Paulo, Esportes, 19 de setembro de 2004.

127 Ibid.

${ }^{128}$ Parte interessada, FPF paga debate da Câmara sobre lei. Folha de São Paulo, Esportes, 10 de novembro de 2004.
} 
de clubes e de federações, com a concordância de advogados, como João Zanforlin e Piraci Oliveira, advogado do Palmeiras, ambos especialistas em futebol. O secretário anunciaria que seria criada a Timemania, programa de loteria que financiaria o pagamento das dívidas dos clubes, prometendo ainda valorizar os clubes formadores de atletas e criar legislação trabalhista adaptada às condições do futebol ${ }^{129}$. Oliveira criticou $^{130}$ fortemente a proposta da Timemania, alegando que a carga tributária dos clubes passaria de $4 \%$ para $30 \%$ do faturamento. Aconteciam ainda conferências regionais em Fortaleza, Florianópolis, Belém, Campo Grande e Rio de Janeiro.

Ao mesmo tempo, a CBF vinha sendo alvo de fiscalização da Procuradoria Geral do Instituto Nacional do Seguro Social (INSS), por meio de um grupo de trabalho específico para analisar as questões do futebol. O órgão havia detectado que a entidade não estaria recolhendo os $5 \%$ das partidas que organiza, conforme era obrigada pela nova interpretação da lei 8641/93, que dizia respeito ao recolhimento de tributos das rendas dos jogos. O diretor do grupo de trabalho, Sérgio Falcão, dizia ter tentado contato com a CBF para realizar reuniões, mas não teria recebido respostas ou, quando recebeu, o encontro teria sido cancelado de última hora. A partir daí, Falcão desistia de convidar a entidade, deixando a decisão a cargo dela, e prometendo fiscalizá-la. Caso o não recolhimento fosse provado, Ricardo Teixeira seria denunciado pelo Ministério Público, afirmava o diretor. Segundo ele, a dívida, com o INSS, da CBF mais a das federações somava $\mathrm{R} \$ 45$ milhões e a dos clubes somariam R\$387 milhões, envolvendo 441 clubes de futebol.

Já os jogadores, que não se articulavam tanto para defender seus interesses, tinham como representante mais atuante o Sindicato dos Atletas Profissionais de São Paulo, que pressionou, por meio de seu presidente, Rinaldo Martorelli, para conseguir que houvesse uma alteração no projeto do estatuto para igualar os valores da cláusula penal e da multa rescisória, pois, até então, em caso de rompimento de contrato, os atletas pagavam duas mil vezes o valor de seus salários e os clubes quatrocentas. Tratou-se de uma vitória para os atletas e Martorelli prometia continuar acompanhando a comissão que analisava o projeto, conversando constantemente com

\footnotetext{
${ }^{129}$ Loteria para salvar os clubes sai este ano. O Estado de São Paulo, Esportes, 09 de novembro de 2004.

${ }^{130}$ Pacote do esporte recebe críticas. O Estado de São Paulo, 10 de novembro de 2004.
} 
políticos participantes dela, pois temia a pressão ${ }^{131}$ exercida pelos clubes.

O Clube dos 13 iria propor uma série de sugestões a serem apresentadas à comissão. Outra sugestão que entrou foi a do Banco Central ${ }^{132}$, de obrigar o reconhecimento, por instituições chanceladas pelo órgão, do dinheiro obtido com a venda de jogadores, jogos e premiações no exterior, ao entrar no Brasil. Porém, as discussões sobre o estatuto se arrastaram por muito tempo, sem que fossem tomadas decisões. As reuniões já se esvaziavam ${ }^{133}$, como quando, em uma delas, apenas cinco deputados, Nabil Abi Chedid e Rinaldo Martorelli aceitaram convite da Câmara para debater a matéria.

Em 2004, os clubes voltaram a pedir a reabertura do programa de refinanciamento das dívidas tributárias, o Refis, para parcelarem suas dívidas de acordo com o faturamento mensal. $\mathrm{CBF}$, federações e clubes reativavam a bancada de parlamentares que defendiam os interesses dos clubes. Queriam dinheiro, por meio leis de benefício ao futebol. Pretendiam ganhar $1 \%$ do total com as loterias federais e um "Refis" especial para o futebol. Clubes falariam com prefeitos, deputados federais e políticos influentes de suas cidades, em busca de benefícios fiscais. O Corinthians iria atrás de José Genoíno, conselheiro vitalício do clube. A Federação Paulista de Futebol falaria com Geraldo Alckmin e Antônio Palocci e sua aproximação com a CBF fortalecia os clubes e federações ${ }^{134}$. A CBF tinha doado $\mathrm{R} \$ 1,13$ milhão a 14 parlamentares em 2002, entre eles os senadores Renan Calheiros (PMDB-AL), Delcídio Amaral (PT-MS), Leomar Quintanilha (na época, no PFL-TO) e José Rocha (PFL-BA) que, já como deputado, foi membro suplente da Comissão de Turismo e Desporto da Câmara dos deputados.

O último destino do projeto de lei do Estatuto do Desporto na Câmara foram reuniões na comissão especial, que analisava o projeto. O relator, Gilmar Machado, reconheceu que foi dado tratamento separado ao futebol em alguns momentos, pois tal esporte teria caraterísticas próprias. Além de, anteriormente, ter salientado que foi retirada do projeto a ideia de limitar em dois o número máximo de mandatos de

\footnotetext{
${ }^{131}$ Painel FC, Folha de São Paulo, 10 de abril de 2005.

${ }_{132}$ Painel FC, Folha de São Paulo, 27 de junho de 2005.

${ }^{133}$ Painel FC, Folha de São Paulo, 12 de abril de 2005.

${ }^{134}$ Dinheiro leva futebol a reativar "bancada da bola". Folha de São Paulo, Esportes, 06 de fevereiro de 2004.
} 
dirigentes de entidades esportivas, Machado ${ }^{135}$ argumentava que os parlamentares resolveram garantir a liberdade de associação dos clubes, baseando-se no artigo 217 da Constituição, e considerando que muitos clubes não tinham interesse em se transformar em empresas. No entanto, ressaltava que os que possuíssem departamentos profissionais deveriam criar departamentos financeiros, de acordo com o que estabelecia o Código Civil, ou seja, com contabilidade, na forma de associação.

Ao mesmo tempo em que o relator afirmava que apenas alguns itens seriam especialmente dedicados ao futebol, outro projeto, de origem do poder executivo, entrou em pauta e os deputados da comissão sentiam que tal projeto poderia atrapalhar toda a discussão realizada por eles durante muito tempo. Tratava-se do projeto de lei 5186/05, que foi entregue com pedido de urgência, e previa a definição de novas regras de relacionamento profissional entre atletas e entidades desportivas e o aumento no repasse de recursos para os clubes formadores de atletas, tanto das modalidades olímpicas quanto do futebol. O deputado Silvio Torres (PSDB), que foi relator da CPI da CBF/Nike, a qual resultou no projeto do Estatuto do Desporto, considerava ${ }^{136}$ que o projeto do Executivo tratava de assuntos que poderiam ser contemplados pelo Estatuto, pois a intenção era fazer uma legislação que abarcasse todos os esportes.

O deputado Dr. Rosinha, que participou das discussões do projeto da lei Maguito Vilela, e dizia que muitos interesses entraram em jogo na ocasião, considerava que, no caso do debate sobre o estatuto, os parlamentares conseguiram muitos avanços e que o projeto 5186/05 prejudicaria o trabalho realizado por eles. Rosinha propôs uma articulação política para derrubar o regime de urgência no qual o projeto tramitava:

"Sei que houve um requerimento para que o projeto fosse apensado. Como esse projeto já esteve na pauta para receber emendas e saiu de pauta, não poderia mais ser apensado, por questão regimental, e não por questão de mérito. Então, se regimentalmente não é possível apensá-lo - solicitação do nosso Relator - nós podemos então fazer o trabalho político com as nossas bancadas, e nós 2 principalmente temos um papel importante por sermos da base do Governo, para

${ }^{135}$ Em discurso na reunião ordinária da comissão especial que analisou o projeto do estatuto, no dia 22 de junho de 2005. Disponível em: http://www.camara.leg.br/internet/sitaqweb/TextoHTML.asp?etapa=11\&nuSessao=0927/05 ${ }^{136}$ Ibid. 
retirar esse regime de urgência. E que nos seja dado algum prazo, porque tenho absoluta certeza de que, com o trabalho que nós temos, rapidamente conseguiremos saber o que é útil e o que é bom trazer para cá."137

Torres não queria dar continuidade à votação de seu projeto, temendo que o novo projeto pudesse prejudicar a decisão tomada pelos deputados naquela votação. Porém, o deputado Marcelo Guimarães Filho (PFL-BA) indagou o relator se o projeto do Estatuto do Desporto, caso aprovado, não revogaria a lei Pelé. Com a resposta positiva de Machado, Guimarães propôs seguir com a votação do estatuto, já que ele, se aprovado, revogaria a lei Pelé, o que impediria que houvesse alguma alteração em tal lei, que era justamente o que o projeto do Executivo sugeria. Ou seja, a lei Pelé não poderia ser alterada pelo novo projeto, porque outra legislação entraria em vigor. O argumento convenceu Silvio Torres e o projeto do estatuto foi aprovado na Comissão.

Contudo, não foi evitado que o projeto 5186/05 entrasse em tramitação. Ele entrou para análise de uma comissão especial na Câmara, porém com o pedido de urgência para apreciação do projeto cancelado ${ }^{138}$. Em 2006, a pedido do ministro Agnelo Queiroz, o projeto entra em regime de urgência urgentíssima. Enquanto isso, Gilmar Machado entra com um pedido para apensação ao projeto 4874/2001 (Estatuto do Desporto). No entanto, o pedido é negado e, em 2008, outra comissão é criada para analisar o projeto. Dela participaram muitos convidados pela Câmara, como dirigentes de futebol, por exemplo, Ricardo Teixeira, Fabio Koff, Marco Aurélio Cunha (então superintendente de futebol do São Paulo Futebol Clube), Andres Sanchez, Marco Polo del Nero e Roberto Dinamite (então presidente do Vasco da Gama); ex-jogadores, como Wilson Piazza e Rinaldo Martorelli (que era presidente do Sindicato dos Atletas Profissionais do Estado de São Paulo); jornalistas, como Milton Neves; e empresários, como Helio Viana e Leo Rabello, então presidente da Associação Brasileira de Agentes de Futebol.

Em 16 de dezembro de 2008, foi dado o parecer do relator da comissão, José Rocha, que foi aprovado ${ }^{139}$, estabelecendo medidas como o estabelecimento de uma

\footnotetext{
${ }^{137}$ Ibid.

${ }^{138}$ Mensagem número 397, de 2005, da Presidência da República.

${ }^{139}$ Câmara conclui votação de mudanças na Lei Pelé. Câmara Notícias, 02 de março de 2010.
} 
cota de 5\% para os clubes formadores, em relação aos valores de transferências nacionais de jogadores. Para aqueles que contribuíram com a formação dos atletas dos 14 aos 17 anos, a cota seria de $1 \%$ do total da negociação, para cada ano de investimento no jogador. Receberiam, ainda, os que investiram na formação entre 18 e 19 anos, uma cota de $0,5 \%$ do valor da transferência. Poderiam assinar contratos aqueles que possuíssem 16 anos ou mais, o que contrariou uma emenda proposta por Silvio Torres, que permitia a realização de contratos com 14 ou 15 anos. Os clubes foram beneficiados com um artigo que impedia que ações judiciais de dívidas das entidades fossem executadas, para casos em que a cobrança comprometesse o funcionamento dos clubes.

Os contratos de trabalho entre jogadores e clubes deveriam prever indenizações tanto para clubes quanto para atletas, respeitando limites. Em caso de transferências para clubes dentro do Brasil, o valor da indenização giraria em torno de duas mil vezes o valor médio do salário. Já em caso de transferências para o exterior, não haveria limites estabelecidos. Os clubes teriam que pagar compensação, correspondente, no mínimo, ao total de salários mensais de direito dos jogadores até o fim do contrato e, no máximo, ao equivalente a 400 vezes o salário mensal, aos atletas que tivessem seus contratos rescindidos por falta de pagamento de salário e dispensa sem motivos. Por fim, havia uma medida que procuraria restringir abusos de empresários, proibindo que estes exigissem valores parciais ou totais das indenizações recebidas dos clubes nas transferências, além de proibir o gerenciamento de carreiras dos jogadores menores de 18 anos.

Portanto, os deputados da comissão do Estatuto do Desporto tentaram impedir a tramitação do projeto 5186/05, mas não conseguiram e tal projeto alterou pontos da lei Pelé, que não foi revogada pelo estauto. A princípio, os parlamentares conseguiram retirar a urgência, mas o projeto tramitou na Câmara, o que mostrava vontade do governo em tratar separadamente de questões ligadas ao futebol, como questões de contrato de trabalho entre clubes e atletas, e a situação jurídica e fiscal dos clubes. O projeto foi para o Senado (PLC 9/2010) e sofreu apenas pequenas alterações, voltando à Câmara, onde foi aprovado. 


\subsection{2) Timemania}

O governo, em 2005, elaborava o projeto que resultaria na Timemania ${ }^{140}$, que não abordava muito a questão das relações de trabalho, já muito trabalhadas em discussões e leis anteriores. Os clubes continuavam tentando promover mudanças no quesito relações trabalhistas e o governo estava disposto a dar algumas garantias a eles. Inclusive, era noticiado que estaria nos planos do Ministério dos Esportes um pacote de medidas que poderia aumentar o valor das multas de jogadores formados nos clubes em $500 \%$, favorecendo os clubes que investissem mais em categorias de base, que teriam compensação maior nas negociações ${ }^{141}$. A proteção ao clube formador estava no projeto da Timemania, mas a loteria foi separada para tramitar mais rapidamente. Lula sinalizava priorizar tal proteção. Enquanto isso, a CBF procurava se aproximar da presidência da Câmara e expandir sua base aliada, pois havia sofrido algumas perdas, como Pedro Corrêa (PP-PE) e Bispo Rodrigues (PL$\mathrm{RJ}$ ), que tinham sido cassados e José Janene (PP-PR) corria o mesmo risco. Weber Magalhães (PFL), vice-presidente da confederação no centro-oeste, seria candidato a deputado federal e acompanhava Teixeira nas visitas ao Planalto e ao Congresso. Ainda havia dois presidentes de federações no parlamento: Marco Antônio Vicente, deputado federal do PTB-ES e Leomar Quintanilha, senador agora pelo PMDB$\mathrm{TO}^{142}$.

Em 2005, viria a Timemania, loteria criada para ajudar os clubes a equilibrarem suas contas, que entrava como medida provisória (MP n. 249/05). A ideia também era usar parte dos recursos arrecadados - talvez metade da arrecadação - para suprir os atrasados com a União. Os clubes não entendiam muito bem como seus débitos seriam liquidados pela loteria. O prazo para os pagamentos seria de 60 meses, o que também era alvo de reclamação dos clubes, que não achavam possível e

\footnotetext{
${ }^{140} \mathrm{Na}$ década de 70, um instrumento semelhante à Timemania foi utilizado. Tratava-se da Loteria Esportiva, que era formada por bilhetes que continham os jogos da rodada, que eram alvo das apostas daqueles que jogavam em tal loteria. Os valores arrecadados serviriam para ajudar nas finanças dos clubes. No entanto, foi descoberto, pela revista Placar, um esquema de manipulação na loteria, envolvendo as mais variadas personagens, que acabou reduzindo significativamente a importância de tal jogo. Chiarioni, Bruno e Kroehn, Márcio. Onde o esporte se reinventa: histórias e bastidores dos 40 anos de Placar. Primavera Editorial. São Paulo, 2010. pp. 147-192.

${ }^{141}$ Novos contratos penalizam cofre de times e CBF. Folha de São Paulo, Esportes, 27 de maio de 2005.

${ }^{142}$ Confederação articula no Congresso. Folha de São Paulo, Esportes, 07 de abril de 2006.
} 
já pediam nova renegociação de suas dívidas. A Caixa previa que a loteria renderia $\mathrm{R} \$ 500$ milhões no primeiro ano. $\mathrm{O}$ início estaria previsto para dali a 6 meses. Do que fosse arrecadado com a Timemania, 25\% iriam para os clubes (65\% para os times da série A, 25\% para os da B e 10\% para os da C). $46 \%$ pagariam a premiação, $20 \%$ iria para o custeio e manutenção, $5 \%$ para projetos sociais do esporte, $3 \%$ para o fundo penitenciário nacional e $1 \%$ para a seguridade social. Os dirigentes tentavam, no Senado, aumentar o prazo para pagar as dívidas na Timemania - que já aumentara para 120 -, para 240 meses. Ofereciam como contrapartida mecanismos de fiscalização do pagamento dos impostos atuais.

O senado aprovou a loteria, com uma emenda, de autoria de Álvaro Dias, que vetava a adesão à loteria dos clubes dirigidos por presidentes que já tinham sido condenados em qualquer esfera da Justiça por crime doloso ou contravenção. A extensão do prazo para pagamentos foi estendida, mas não para 240, como queriam os clubes, e sim para 180 meses.

A Timemania foi aprovada em setembro. Mas os clubes queriam avanços na questão da proteção aos que perdiam jogadores sem remuneração. Também queriam a regulamentação do contrato de direito de imagem, que tinha o reconhecimento da Justiça Trabalhista como direito trabalhista, o que gerava indenizações milionárias contra os clubes. Ao mesmo tempo, jogadores, por meio de advogados e da Federação Nacional de Atletas Profissionais, queriam que o dinheiro fosse usado para sanar dívidas trabalhistas. O vice da federação, Rinaldo Martorelli, orientava os jogadores a buscarem direitos sobre a Timemania e dizia que poderiam até entrar com uma ação coletiva para requisitar a penhora. Se a ação vingasse, o Clube dos 13 alegava que os clubes teriam que pagar as dívidas do próprio bolso. O percentual que cada clube receberia ainda seria acertado na regulamentação da lei. $\mathrm{O}$ que era certo era que todos teriam direito a $22 \%$ do arrecado pela Timemania. A comissão que regulava a Timemania avaliava que o dinheiro poderia ser realmente penhorado, porque a legislação dava prioridade às dívidas trabalhistas em relação às fiscais. O principal objetivo da comissão era regular a lei da loteria para evitar tal penhora.

Em 2007, Lula sancionava a Timemania, vetando emenda que permitia aos clubes parcelarem dívidas que seguiriam questionadas na Justiça. O Ministério da Fazenda alegava que os clubes já haviam sido muito beneficiados com a loteria. Mas, 
em 2010, seus resultados não atingiram o que era esperado. A expectativa era que a loteria arrecadasse cerca de $\mathrm{R} \$ 540$ milhões. O resultado ficou em cerca de $\mathrm{R} \$ 112$ milhões, apenas $20,7 \%$ do pretendido. Após três anos de atividade da loteria, as dívidas, ao invés de diminuírem, aumentaram de $\mathrm{R} \$ 2,57$ bilhões para $\mathrm{R} \$ 3,24$ bilhões. Aumentava também, em 19\%, o volume das dívidas somente contando o período com a Timemania, apesar do crescimento do valor total do endividamento ter sido menor, colocando a Timemania nas contas de 2009 a 2011, segundo estudo de Somoggi (2012), publicado em balanço da $\mathrm{BDO}^{143}$ sobre as finanças dos clubes em $2011 \mathrm{e}$ 2012.

Em 2012, já no governo de Dilma Rousseff, uma proposta de reforma da lei Pelé ameaçava os dirigentes de responder solidária e ilimitadamente por gestão temerária e atos ilícitos ou contrários ao previsto no estatuto dos clubes. Em 2013, é aprovado projeto para limitar o mandato dos dirigentes esportivos. Eles só poderiam ser reeleitos uma vez a mandatos de até quatro anos e cônjuges e parentes de segundo grau não poderiam ser eleitos. O autor da proposta, Cássio Cunha Lima (PSDB-PB) disse que tentavam aprovar esse projeto há 30 anos, mas a "bancada da bola" impedia. A CBF temia que o deputado federal Romário (PSB-RJ), ex jogador, incluísse a entidade máxima na lei. $\mathrm{O}$ diretor de assessoria legislativa da CBF trabalhava com políticos nessa meta e conseguiu atingi-la, já que o projeto falava apenas em entidades que recebessem apoio estatal, que não era o caso da $\mathrm{CBF}$, mas sim de alguns clubes, que possuíam patrocínios vinculados ao Estado, e também dos clubes que poderiam renegociar suas dívidas com o governo. A aprovação do projeto que limitava os mandatos dos dirigentes teve como destaque uma grande mobilização de atletas e ex atletas, com a ajuda da entidade "Atletas pelo Brasil", que foram fundamentais para tal aprovação, assim como a presidenta da República, a ministra Ideli Salvati e a senadora Ana Rita (PT-ES).

${ }^{143}$ BDO é uma empresa de origem britânica, que presta consultorias e realiza auditorias, e, no Brasil, tem a filial BDO RCS, que faz auditorias independentes. Foi utilizada aqui pois fez estudos sobre as finanças dos clubes brasileiros nos últimos anos. O objetivo foi utilizar esses dados para mostrar a evolução das dívidas dos clubes. 
Atualmente, a dívida dos clubes está na pauta das discussões do Congresso Nacional. Há projetos que tratam da renegociação das dívidas dos clubes com o Instituto Nacional do Seguro Social (INSS), Imposto de Renda, Fundo de Garantia do Tempo de Serviço (FGTS) e Banco Central, destacando-se o projeto da Lei de Responsabilidade Fiscal do Esporte, que já chegou à Câmara, mas ainda aguarda para ser votado.

Antes de tratar de tal projeto, deve-se olhar para o parâmetro das dívidas que os clubes alcançaram. As receitas de muitos dos grandes clubes cresceram, porém, segundo o estudo da BDO 2012, feito com base na análise dos balanços dos clubes, o endividamento também cresceu e, na realidade, cresceu mais do que as receitas, com aumento de $126 \%$, e o total devido está em cerca de $\mathrm{R} \$ 4$ bilhões. Esse número não é muito exato, pois, em determinados momentos, se fala em $\mathrm{R} \$ 3$ bilhões, outros em $\mathrm{R} \$ 5$ bilhões, e nem o próprio governo sabe com clareza qual é o montante que está em débito.

A evolução das receitas, com o peso do custo dos departamentos de futebol, pode ser acompanhada no Gráfico 2, desenvolvido por tal estudo da BDO:

\section{Gráfico 1:}

\section{Receita Total, Custo do Departamento de Futebol e \% Custo Futebol 20 Clubes - Em R\$ milhões}

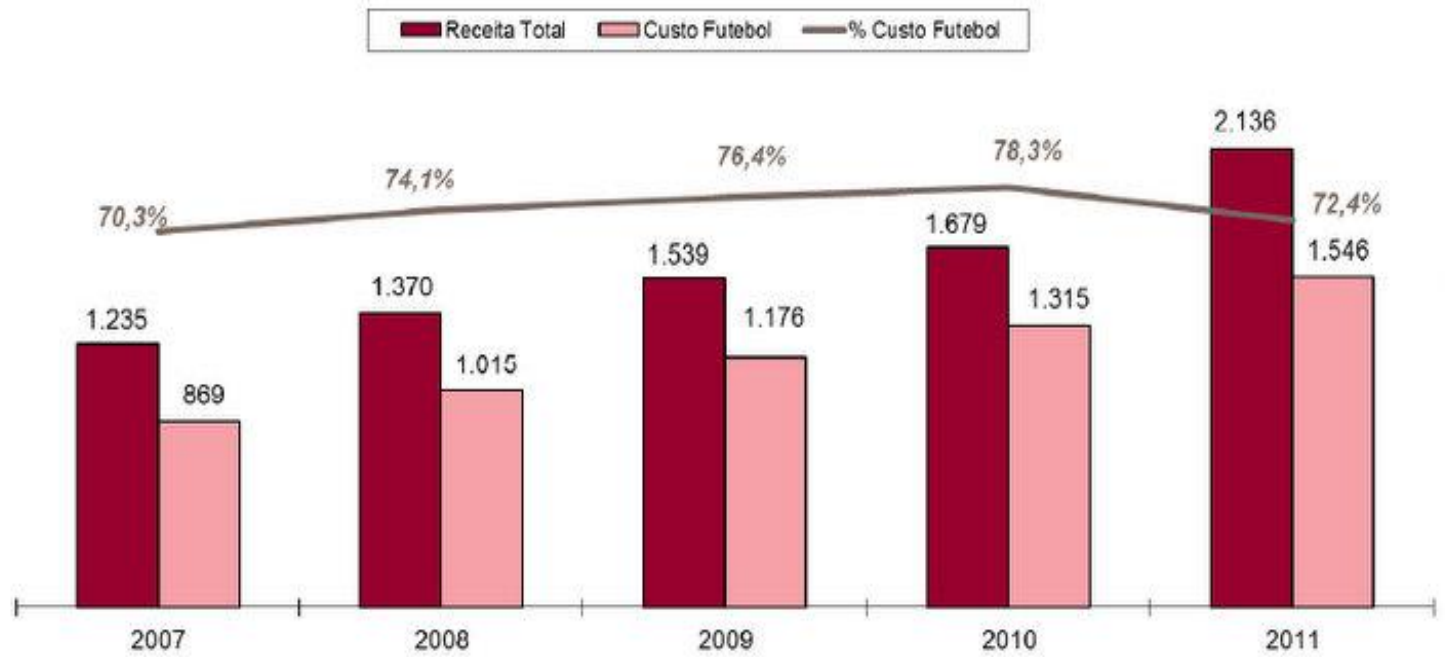

Fonte: Somoggi, Amir. Finanças dos Clubes de Futebol do Brasil em 2011 e 2012. BDO, Maio de 2012. 
Como pode ser visto, a maior parte do que se gasta das receitas arrecadadas pelos clubes vai para o futebol, que já chegou a representar quase $80 \%$ dos custos das entidades. O mesmo estudo mostra que as dívidas, de 2009 a 2011, aumentaram em 42\%. O estudo da BDO para 2013 mostra que as dívidas continuaram crescendo, alcançando o patamar de 5,6 bilhões. Estendendo o período anterior considerado (2009-2011), para 2009-2013, o crescimento das dívidas foi de 98\% (de praticamente $\mathrm{R} \$ 2,8$ bilhões para $\mathrm{R} \$ 5,68$ bilhões $)^{144}$.

Os dados mais recentes confirmam o aumento das dívidas e os gastos com o futebol, conforme informam os dados da BDO de $2014^{145}$, que mostrou que os custos com os departamentos de futebol dos 23 clubes estudados aumentaram em $\mathrm{R} \$ 365$ milhões de 2012 para 2013, enquanto que as receitas aumentaram $\mathrm{R} \$ 58$ milhões.

Em outras palavras, os clubes recebem cada vez mais dinheiro, mas, ao mesmo tempo gastam cada vez mais, e numa proporção maior do que o que recebem. Esse estilo de administrar não tem agradado os jogadores que, por vezes, acabam prejudicados, pois acabam deixando de receber o que teriam direito. Ao mesmo tempo, aceitam, nas negociações, os valores superestimados que os dirigentes oferecem para conseguirem contratar atletas que agradariam as torcidas. Mas, os jogadores exigem mudanças nas práticas administrativas dos clubes, assim como o governo, pois uma parcela elevada das dívidas são dívidas fiscais, que atualmente

\footnotetext{
${ }^{144}$ Reportagem da Espn Brasil, que teve acesso à lista dos devedores da Procuradoria Geral da Fazenda Nacional, mostrou o endividamento das grandes equipes do sul e sudeste: 1) Atlético-MG: R \$ 272 milhões 2) Flamengo: R\$ 253 milhões 3) Botafogo: R\$ 199 milhões 4) Corinthians: R\$ 172 milhões 5) Fluminense: $R \$ 162$ milhões 6) Vasco: $R$ \$ 153 milhões 7) Santos: R \$ 65 milhões 8) Palmeiras: R 46 milhões 9) Grêmio: $\mathrm{R} \$ 40$ milhões 10) Cruzeiro: $\mathrm{R} \$ 14$ milhões 11) Internacional: $\mathrm{R} \$ 8$ milhões 12) São Paulo: $\mathrm{R} \$ 7,8$ milhões. Neste ranking não estão incluídas as dívidas com Imposto de Renda, cujos valores não podem ser divulgados. De acordo com a Procuradoria Geral da Fazenda Nacional, "os valores informados referem-se, somente, ao montante da Dívida Ativa inscrita cobrada pela Procuradoria-Geral da Fazenda Nacional. A Dívida Ativa alberga todos os créditos públicos para com a União não pagos a tempo e modo devidos". http://espn.uol.com.br/noticia/431880_sao-paulo-deve-trocado-para-governo-atletico-mgfortuna

${ }^{145}$ Daniel, Pedro. “7o Valor das Marcas dos Clubes Brasileiros”. BDO. 2014.
} 
estão na casa dos $\mathrm{R} \$ 2,7$ bilhões (47\% do total devido) ${ }^{146}$ e cresceram $33 \%$ em três anos.

O governo, por meio da Procuradoria Geral da Fazenda Nacional, já vem tomando algumas medidas a fim de renegociar os débitos que os clubes têm com ele, bloqueando o dinheiro da venda de jogadores e das cotas de televisão. Mesmo após a renegociação, o dinheiro que já está bloqueado fica retido em juízo, para o caso de o clube não honrar com o acordo.

\subsection{3) Lei de Responsabilidade Fiscal do Esporte}

Ainda assim, esses números incentivaram a criação de um novo projeto, o da Lei de Responsabilidade Fiscal do Esporte, em 2014, que propunha o parcelamento em 25 anos de tais dívidas, como maneira de os clubes conseguirem pagar o que devem, com a contrapartida de apresentarem uma Certidão Negativa de Débitos (CND), a cada seis meses, que comprove que estão em dia com seus encargos, para que possam receber incentivos fiscais. O projeto foi muito defendido pelo Bom Senso Futebol Clube, movimento de jogadores de futebol recém criado, que pede melhorias na gestão do esporte no país. Porém, o movimento tentava articulações no Congresso, pois, da maneira como estava desenhado o projeto, agradava os clubes, já que a única contrapartida exigida a eles, para que pudessem receber recursos do governo, era a apresentação da Certidão Negativa de Débitos, sem que houvesse responsabilização dos dirigentes por más administrações, sem punições desportivas, como queda de divisão no campeonato nacional, e sem sanções por atos que desrespeitem compromissos feitos com jogadores, como atrasos longos de pagamentos e más condições de trabalho.

Os atletas exigiam contrapartidas mais rigorosas aos clubes, em caso de não pagamento de impostos e salários em dia, envolvendo responsabilização pessoal aos dirigentes dos clubes, perda de pontos, descenso de divisão e tetos salariais - medida pensada na estratégia dos clubes de fazerem contratações com valores muito elevados, como forma de responder às pressões das torcidas, repatriando jogadores de grande prestígio, porém sem possuir recursos financeiros suficientes para bancar tais

\footnotetext{
${ }^{146}$ Ibid.
} 
investimentos, por vezes até mesmo aumentando suas dívidas. Os dirigentes dos clubes queriam que o projeto passasse como estava, inclusive pressionando para que entrasse como medida provisória, para que fosse aprovado mais rapidamente, e esse grupo de jogadores tentava colocar suas reivindicações.

Em julho, Toninho Nascimento, secretário de futebol do Ministério do Esporte, participou de reunião no Palácio do Planalto, em Brasília, com representantes de clubes e do governo para discutir o projeto e já havia se reunido com representantes dos jogadores. A avaliação dele foi que, antes de o texto ser votado no Congresso, seria preciso que houvesse consenso entre clubes, jogadores, governo, Legislativo e Advocacia Geral da União (AGU), para garantir a legitimidade do projeto. O líder da comissão dos clubes junto à $\mathrm{CBF}$, presidente do Coritiba, e chefe da delegação da seleção durante a Copa do Mundo, Vilson Ribeiro, dizia que as propostas do Bom Senso estavam praticamente todas inseridas no que propunham os clubes e que as propostas dos clubes eram até mais radicais que a do movimento, que discordou, afirmando que defendiam a criação de um órgão fiscalizador independente para acompanhar as atividades financeiras dos clubes, a prestação de conta trimestrais, que, se não efetivadas, gerariam punições desportivas aos clubes e responsabilização pessoal dos dirigentes, a obrigatoriedade de manter em dia carteira de trabalho, direitos de imagens e salários dos funcionários, a avaliação anual de endividamento e fiscalização anual, o controle do custo com o futebol, e a apresentação da Certidão Negativa de Débitos com frequência de um mês antes de cada competição. O Bom Senso ainda rebatia a afirmação de Ribeiro, dizendo que os clubes sim queriam algo conservador, com aprovaçao imediata da lei, com poucas contrapartidas a eles ${ }^{147}$.

Havia uma expectativa de o projeto ser votado no início de agosto de 2014, mas não foi para o plenário da Câmara dos Deputados e teve adiamento para setembro, muito por conta da insatisfação do Bom Senso com o texto final apresentado pelo deputado Otavio Leite, o relator. As principais críticas foram a falta de controle e fiscalização das contrapartidas em relação ao parcelamento que seria oferecido aos clubes, a definição de quem seria o responsável por tais acompanhamentos e a falta de proposição para a questão do atraso de pagamentos dos clubes com os atletas. No

${ }^{147}$ Governo espera aprovar lei fiscal dos clubes até setembro, diz secretário. Filipe Matoso. Do G1, em Brasília, 25 de julho de 2014. 
Congresso, houve protesto e apresentação de ideias dos atletas ${ }^{148}$.

No entanto, um outro ponto foi tão responsável, ou até mais, pelo atraso na votação, uma disputa entre governo e deputados a respeito dos juros a serem pagos pelos clubes. A taxa de juros que estava no texto, que os clubes queriam, era a TJLP (Taxa de Juros de Longo Prazo), de 5\% ano. O governo queria a Selic, de 11\%. Uma dívida de R 4 bilhões, com a TJLP, passaria para R \$ 4,2 bilhões depois de 12 meses, e para R \$ 4,42 bilhões, utilizando a Selic. Segundo o presidente do Coritiba, antes de discutir qualquer outra coisa, como por exemplo a fiscalização das contrapartidas da lei, era preciso definir essas questões. Além disso, o governo queria que o tempo do prolongamento do pagamento fosse menor do que o que estava no projeto. No entanto, desde as reuniões dos clubes e do Bom Senso com a presidenta Dilma Rousseff, o governo não mais se pronunciou. O relator do projeto, Otavio Leite, se preocupava com conversas que corriam nos batidores do Congresso, sobre a possibilidade de o governo fazer uma Medida Provisória para passar o projeto, o que, até o momento, não aconteceu ${ }^{149}$.

Ao mesmo tempo em que aconteciam conversas intra-Congresso, os grupos também se movimentavam entre eles. A CBF fazia reunião com clubes das duas primeiras divisões do futebol nacional, em determinado momento, e, posteriormente, séries C e D para discutir diferentes temas sobre a o futebol. Um dos assuntos abordados foi a Lei de Responsabilidade Fiscal do Esporte. A entidade pediu que dirigentes fizessem pressão sobre parlamentares de seus Estados. A Rede Globo também conversou com os clubes das série C e D, mostrando-se favorável à aprovação do dispositivo no formato que estava e fazendo campanha para que permanecesse de tal forma. O diretor da Globo Esporte, Marcelo Campos Pinto, falou aos clubes sobre a importância do mecanismo para o futuro da modalidade, defendendo o argumento de que a sobrevivência da gestão de clubes brasileiros dependeria do refinanciamento das dívidas. Na relação com os parlamentares, os

\footnotetext{
${ }^{148}$ Governo promete contraproposta ao Bom Senso, e votação deve acontecer em setembro. Camila Mattoso, de Brasília (DF), do ESPN.com.br, 05 de agosto de 2014.

${ }^{149}$ Juro camarada e prazo fazem governo travar ajuda a clubes. Camila Mattoso, de Brasília, para o ESPN.com.br, 05 de agosto de 2014
} 
atletas foram apoiados pelo deputado federal Romário (PSB-RJ) e pelo senador Randolfe Rodrigues (PSOL-RN), que fazia corpo a corpo com parlamentares. Enfrentam a resistência de clubes, federações e CBF, apoiados pela "bancada da bola", liderada pelo deputado Vicente Cândido (PT-SP), vice-presidente da Federação Paulista de Futebol (FPF) ${ }^{150}$.

Recentemente, o Bom Senso enviou uma carta para os candidatos à presidência da República, pedindo compromisso com as pautas defendidas pelo movimento. Dilma Rousseff, reeleita, se mostrava a favor dos atletas. Por outro lado, eles foram supreendidos com uma série de mudanças no texto, promovidos com a ajuda do advogado Álvaro de Melo Filho, que trabalha junto à CBF e aos clubes há um bom tempo. Os clubes decidiram não comparecer a uma reunião com representantes do governo, em Brasília e enviaram o texto - sem a garantia do teto salarial que os jogadores pediam, sem a punição de exclusão de campeonatos por razões financeiras da lei, com o prazo de 5 anos para a lei entrar em vigor e o recebimento de benefícios imediato, somente com a contrapartida da apresentação anual da CND -, para a Câmara dos Deputados, pedindo regime de urgência para a votação $^{151}$.

Houve uma reunião entre representantes do Bom Senso, o jogador Paulo André e o técnico Paulo Autuori, com o ministro da Casa Civil, Aloizio Mercadante. Os porta-vozes do movimento mostraram otimismo com o encontro, em que Mercadante se mostrou a favor da reivindicação do Bom Senso de democratização no poder do esporte no país, com participação de atletas em decisões e eleições. Ficou prometida uma consulta ao movimento antes da Casa Civil enviar o texto final ao Congresso $^{152}$.

O projeto avançou no ano de 2015 e foi aprovado, pela Câmara e pelo Senado, e sancionado pela presidência, com vetos a ainda serem apreciados pelo Congresso,

${ }^{150}$ Lei de Responsabilidade Fiscal do Esporte ameaça o futebol. José Antonio Lima, Esporte Fino, 07 de agosto de 2014.

${ }^{151}$ Carta aberta aos candidatos à presidência da República. Juca Kfouri, 21/10/2014

${ }^{152} \mathrm{http} / / /$ blogdojuca.uol.com.br/2014/11/o-bom-senso-fc-na-casa-civil/ 
como o veto à transformação dos clubes em sociedades comerciais ${ }^{153}$.

A aprovação, até então, se deu com características muito próximas ao que agradava as reivindicações do grupo de jogadores do Bom Senso e de uma boa parcela da imprensa. Os pontos aprovados foram o financiamento das dívidas fiscais dos clubes em 240 meses, seguindo a taxa Selic. Os clubes que deixarem de pagar três parcelas perderão o refinanciamento. Terão ainda os clubes que se limitar a gastar $80 \%$ das suas receitas totais para pagar salários e direitos de imagem de atletas, apresentar Certidão Negativa de Débitos à Receita Federal para disputar competições, sob pena de rebaixamento de divisão, não poderão antecipar verbas, como as de direito de televisão, modificar seus estatutos para prever possibilidade de afastamento e inelegibilidade de dirigentes que praticarem gestão temerária, limitar o tempo de mandato dos presidentes a quatro anos e uma reeleição, manter um conselho fiscal autônomo e regularizar obrigações trabalhistas e tributárias. ${ }^{154}$

No entanto, esses eventos não serão aqui analisados, pois o recorte de tempo aqui utilizado foi até o primeiro mandato de Dilma Rousseff, e os acontecimentos ainda são muito recentes, o que indica a possibilidade de ser cedo para avaliar quais são os impactos que a aprovação do projeto irá trazer para o futebol brasileiro.

Muito foi feito, ou muitas tentativas foram feitas, com o objetivo de mudar a situação da administração dos clubes, desde a Lei Zico, que tentou colocar os clubes oficialmente no contexto da modernização, ao propor a transformação facultativa das entidades em empresas, o que faria com que tivessem que pagar impostos como qualquer outra empresa. Esse item do projeto de Zico não entrou na lei e Pelé tentou novamente, conseguindo alguns avanços, mas com muitas restrições, colocadas pelos clubes, que se organizaram tanto dentro como fora do Congresso para garantir que seus interesses prevalecessem.

Essa atuação continuou com as tentativas seguintes de mexer na forma como as entidades administravam o futebol e na questão das dívidas cada vez maiores que

153 http://blogdojuca.uol.com.br/2015/09/decisao-no-congressonacional/?utm_source=dlvr.it\&utm_medium=facebook

154 http://blogdojuca.uol.com.br/2014/12/gambiarra-da-cartolagem-tem-chance-zero-devigorar/ http://www.lancenet.com.br/minuto/MP-Profut-aprovadaSenado_0_1393060830.html http://www12.senado.leg.br/noticias/materias/2015/08/06/mp-do-futebol-e-sancionada-comvetos 
elas faziam com o governo. Não foi formada uma convergência de interesses, como no caso das relações de trabalho entre clubes e jogadores, favorável a mudanças significativas no status quo. Os grupos contrários a tais mudanças se movimentaram para evitá-las. Em alguns momentos, até aceitaram pequenas mudanças, mas para que a estrutura de poder que eles mantêm não fosse alterada e, ainda, para que medidas que trouxesse benefícios a eles estivessem dentro dessas pequenas mudanças. Até hoje, os clubes continuam devendo muito dinheiro aos cofres públicos, alguns ainda não cumprem seus compromissos com os atletas, apesar de já sentirem o peso de sanções impostas pelo governo, e as federações, e a CBF, continuam com sua estrutura de poder, sem que demais interessados, como jogadores, possam participar de decisões ou de processos eleitorais, que definem quem será responsável pela administração dos clubes e do futebol, de maneira geral, no país. 


\section{Capítulo 4: Grupos de interesse e modernização do futebol brasileiro}

Reconstituído o debate que ocorreu em torno de questões chave relativas ao processo de modernização do futebol brasileiro nos últimos anos, interessa agora realizar uma análise dos acontecimentos, a luz das referências teóricas inseridas nos debates da ciência política, anteriormente citadas. Este último capítulo será dividido em duas partes, uma com a descrição dos grupos de interesse envolvidos nas questões abordadas, e a outra com a análise em si.

\section{1) Os grupos de interesse envolvidos}

Como a parte empírica do trabalho mostrou, alguns grupos de interesse estiveram envolvidos nas discussões, dentro do universo político, dos momentos chave do processo de modernização do futebol brasileiro. Importa mostrar quais são as características dos grupos, se for o caso suas histórias, como se relacionam com a atuação na arena política, e as particularidades dentro de cada grupo (por exemplo, o grupo "clubes de futebol” talvez não seja tão homogêneo o tempo todo, assim como jogadores, meios de comunicação, etc). Os grupos analisados serão: CBF; federações estaduais; clubes; jogadores; meios de comunicação (TV, jornalistas, etc).

\section{a) $\mathrm{CBF}$}

A Confederação Brasileira de Futebol, órgão maior do futebol brasileiro ${ }^{155}$, que o organiza e o comanda, tendo como filiados federações, clubes e atletas, organizando campeonatos (suas tabelas, calendários, formas de disputa, etc) e, basicamente, decidindo todos os destinos de nosso futebol, talvez tenha sido o grupo de interesse com atuação mais organizada e enfática em torno de suas preferências com relação a questões colocadas em discussão na arena política (e também fora dela) que poderiam alterar a situação vigente da entidade.

A CBF se movimentou intensamente para alcançar seus objetivos, procurando atuar sobre as diversas instâncias decisórias do poder público, por vezes através de

${ }^{155}$ Para um estudo mais completo sobre a CBF ver Sarmento (2006). 
doações eleitorais - boa parte delas, como mostraram os relatórios das CPIs - a parlamentares; viabilizando uma estrutura física em Brasília, a fim de facilitar o funcionamento de seus mecanismos de pressão sobre quem decidiria nas questões que a interessavam; realizando viagens de seu presidente para conversar com políticos; enviando dirigentes para participar de debates na Câmara dos Deputados,bem como na então Secretaria de Desportos, comandada por Zico; atuando em questões internas à entidade, mas que interfeririam no seu poder fora do seus domínios também, como no caso da mudança de seu regimento interno, a fim de garantir a reeleição de Ricardo Teixeira; reunindo-se com clubes e federações e fazendo doações também a estes; encomendando seminários em fundações.

Trata-se de um grupo de interesse coeso na defesa de suas preferências, que sempre procurou atuar de maneira homogênea sobre as instâncias decisórias, dos diferentes poderes.

\section{b) Federações estaduais}

As federações são entidades desportivas, vinculadas à Confederação Brasileira de Futebol, que administram o futebol nos estados, à qual os clubes estão filiados. Elas organizam os campeonatos regionais, montando as tabelas e o calendário, e guardam registros dos clubes, jogadores e árbitros filiados. Elas foram alvo de críticas contundentes das investigações das CPIs do futebol, que apontaram que praticamente todas as entidades tinham graves problemas administrativos e financeiros, que deveriam ter atenção do Ministério Público e da Receita Federal, por exemplo.

Quanto à atuação das federações como grupos de interesse, não se pode dizer que se organizaram e se movimentaram tanto como a $\mathrm{CBF}$, mas tiveram uma atuação importante e procuraram, muitas delas, em vários momentos, apoiar as decisões e posições da $\mathrm{CBF}$ em relação às questões aqui abordadas. Atuaram participando de, e patrocinando, debates na Câmara dos Deputados e de seminários em fundações, assim como a CBF; participando de reuniões com a entidade máxima do futebol brasileiro; se relacionando com políticos, em alguns casos com os próprios dirigentes de federações ocupando cargos proporcionais ou majoritários, ou, em outros casos, ocupando tais postos parentes de alguns dirigentes; realizando discursos dentro e fora do campo político, etc.

Trata-se de um grupo não tão bem estruturado quanto à CBF, mas que buscou, em grande parte dos eventos aqui analisados, apoiar tal entidade e que, dificilmente, 
se mostrou pouco coeso ou homogêneo. Em geral, o posicionamento das federações em relação a possíveis mudanças propostas na estrutura do futebol brasileiro coincidiam e elas atuavam no mesmo sentido.

\section{c) Clubes}

Comparando com as organizações anteriores, pode-se dizer que os clubes são onde o futebol é mais "visível", onde os atletas atuam, são os que disputam os campeonatos, que têm a empatia do torcedor. Em sua grande maioria, são vinculados às federações e à $\mathrm{CBF}$, e dependem destas para poder confirmar participação nos principais campeonatos.

Ao decorrer das discussões que se deram no âmbito político sobre a modernização do futebol brasileiro, os clubes também foram um grupo de interesse que atuaram de maneira significativa, afinal de contas, os principais temas envolvidos nas discussões dos projetos de lei e das leis afetariam diretamente a forma como os clubes lidavam com suas administrações e com as relações com seus atletas. Dentre as maneiras como os clubes procuraram defender seus interesses diante do poder público, destaca-se a representação de parlamentares, tanto na Câmara dos Deputados, como no Senado, que procuravam defender as preferências de alguns clubes, votando contra projetos de lei, emendas, instalação de CPIs, etc, que contrariassem tais preferências e a favor de matérias que as favorecessem. Em alguns casos, podiam contar com o apoio de relatores de comissões que analisariam projetos, que são figuras importantes no processo legislativo (Santos e Almeida, 2005); a participação em debates na Câmara e seminários em fundações; reuniões com a CBF e com as federações; reuniões com membros do poder executivo; reuniões com relatores de projetos de lei de seus interesses; discursos na imprensa; e reuniões com a Rede Globo.

O grupo de interesse "clubes", como se percebe, foi bastante atuante, mas não se pode dizer que se trata de um grupo tão coeso e homogêneo quanto $\mathrm{CBF}$ e federações. Por diversas vezes, a grande maioria dos clubes e seus representantes atuaram no mesmo sentido nas decisões que envolviam questões relevantes do futebol nacional, mas isso, de maneira alguma foi uma regra. Em certos casos, alguns se posicionaram mais a favor de mudanças (como nas relações de trabalho e questões administrativas) e, outros, contra elas, caracterizando uma atuação não conjunta. 
Há de se enfatizar também que a figura do dirigente de futebol tem diferenças, ao longo do tempo. Antes, na fase amadora do futebol brasileiro e ainda um bom tempo depois da consolidação da fase profissional, entrando no processo de modernização, muitos eram vistos como o que o senso comum via como "políticos tradicionais brasileiros", ou seja, mandonistas, coronelistas ou populistas, por exemplo, figuras como Eurico Miranda ${ }^{156}$, Vicente Matheus (ex-presidente do Corinthians), Juvenal Juvêncio (ex-presidente do São Paulo) e Mustafá Contursi (expresidente do Palmeiras). Depois, com o paradigma do futebol moderno cada vez mais consolidado, em que o futebol deveria seria tratado como qualquer outro negócio, muitos dirigentes buscam se aproximar dos perfis de empresários, focados nos resultados financeiros do clube, responsáveis e profissionais, por exemplo o atual presidente do Palmeiras, Paulo Nobre, o ex-presidente do Flamengo, Márcio Braga, o atual presidente do Flamengo, Eduardo Bandeira de Mello, e dirigente com cargos como o de diretor de futebol, caso do atual palmeirense e ex-cruzeirense, Alexandre Matos, o ex-vascaíno e atual flamenguista, Rodrigo Caetano, e o atual corintiano, Edu Gaspar.

\section{d) Jogadores}

São os que praticam o esporte, talvez tão visíveis - em alguns casos, até mais quanto os clubes. Tradicionalmente, o jogador, com as notáveis exceções de alguns como Sócrates e Afonsinho, era visto como malandro e, ao mesmo tempo, inocente, quando se tratava de questões como as financeiras e as relações de trabalho com os clubes. Mais recentemente, também com a transformação do futebol em uma atividade estritamente profissional e cada vez mais voltada para o mundo empresarial, nota-se algumas mudanças neste perfil, surgindo jogadores considerados "esclarecidos", com discursos mais polidos, preparados por assessores de imprensa, casos, por exemplo do zagueiro do Cruzeiro, Paulo André, do goleiro do São Paulo, Rogério Ceni e muitos outros que se caracterizam pelo discurso pasteurizado.

Como grupo de interesse, em relação às questões abordadas no processo decisório aqui analisado, a atuação dos atletas foi pouco incisiva, na maior parte do tempo. A defesa de seus interesses se deu mais por meio dos seus sindicatos, referentes a cada estado da federação que os atletas trabalhavam, sendo os mais atuantes o dos atletas profissionais de São Paulo e o do Rio de Janeiro. Os jogadores,

${ }^{156}$ Para entender melhor a figura de Eurico Miranda ver Revista Piauí, Edição 19. Eurico, \#@*!. Rio de Janeiro, abril de 2008. 
sem o trabalho dos sindicatos, mas mesmo com a ajuda dessas organizações, se mostraram pouco homogêneos e coesos. Participaram de reuniões, audiências e debates com o poder legislativo e com o Executivo, mas não em peso, apenas com presenças esporádicas de alguns. Foram auxiliados, em muitos casos, e com sucesso no sentido de aprovar medidas favoráveis a eles, por boa parte da imprensa e pelo governo. Atualmente, se mostram um pouco mais ativos, com a criação do Bom Senso Futebol Clube, que ainda é majoritariamente formado por atletas das principais divisões do futebol brasileiro, o que representa uma pequena parcela da categoria dos jogadores, mas que vem crescendo e atua frequentemente nas decisões do poder público.

\section{e) Meios de comunicação}

Basicamente, a referência aos meios de comunicação aqui é a imprensa esportiva. Boa parte dela cobria os acontecimentos, mas procurava tomar posições sobre eles. Até por isso, é colocada aqui também como grupo, também como parte atuante nas questões. De maneira geral, atuava escrevendo e publicando muito sobre os assuntos, como a administração dos clubes e as relações de trabalho entre estes e os atletas, deixando clara sua posição a favor das mudanças no sentido da modernização.

Em geral, ao menos os veículos que foram analisados aqui, se mostraram como um grupo homogêneo no sentido favorável às mudanças citadas anteriormente. Uma divergência, em alguns pontos, pode ser a Rede Globo, nos momentos em que apoia os grupos contrários a algumas mudanças, como nos casos mais recentes, que dizem respeito à Lei de Responsabilidade Fiscal do Esporte.

\subsection{2) Bancada da Bola}

Cabe destacar que, ao longo desses anos analisados na pesquisa, percebeu-se que muitos membros dos grupos de interesses estudados tiveram representação na arena política, contando com a atuação em seu favor de deputados e senadores. Tal grupo de parlamentares ficou popularmente conhecido como "Bancada da Bola", o que não significa que existiu, ou existe, uma bancada uníssona e homogênea que defenda determinado grupo de interesse do meio futebolístico. São parlamentares ligados aos diversos grupos, como jogadores, federações, CBF e clubes. Por diversas 
vezes, como foi visto, as preferências de alguns grupos eram distintas das de outros, o que não permite classificar como uma bancada que atua sempre no mesmo sentido.

No entanto, em muitos casos, como interesses convergiam, especialmente os de federações e CBF e, em vários casos, também os de clubes, a atuação da bancada acabou por se dar no mesmo sentido. E foram esses os grupos que mais tiveram representantes, notadamente os clubes e a CBF.

A "Bancada da Bola" não é um grupo de interesse, mas cabe destacar seu papel aqui, na defesa de grupos de interesse. Diferente do que analisa Silva (2013), ao estudar a bancada da bola no legislativo carioca, focando no apelo de figuras conhecidas do meio do futebol para efeitos nas eleições, aqui destaca-se a atuação no parlamento para defender os interesses de grupos ligados ao futebol, sejam clubes, federações, $\mathrm{CBF}$ ou jogadores, nos momentos chave do processo de modernização do futebol brasileiro, que passaram pelas instâncias legislativas e de governo.

Existem vários exemplos de nomes de parlamentares que formaram as bancadas da bola ao longo do tempo, alguns deles até ocupando espaços de mais destaque, como relatorias de comissões que analisariam projetos importantes para a área e participação em comissões, tanto as temáticas, como as de inquérito. Os políticos que representaram os diferentes grupos de interesse identificados neste trabalho são os seguintes:

Tabela 1 - Bancadas da bola desde a Lei Zico

\begin{tabular}{|l|l|l|l|l|l|}
\hline Parlamentar & Partido & Cargo & Legislaturas & $\begin{array}{l}\text { Grupo } \\
\text { representado }\end{array}$ & $\begin{array}{l}\text { Matéria } \\
\text { atuação }\end{array}$ \\
\hline $\begin{array}{l}\text { Arnaldo } \\
\text { Faria de Sá }\end{array}$ & $\begin{array}{l}\text { PRN/ } \\
\text { PPB-SP }\end{array}$ & $\begin{array}{l}\text { Presidente } \\
\text { da } \\
\text { Portuguesa/ } \\
\text { Deputado } \\
\text { federal }\end{array}$ & $1990-98$ & Clubes & Lei Zico/ Lei Pelé \\
\hline $\begin{array}{l}\text { Bispo } \\
\text { Rodrigues }\end{array}$ & PL-RJ & $\begin{array}{l}\text { Deputado } \\
\text { federal }\end{array}$ & $1999-05$ & CBF & Timemania \\
\hline Carlos & PT-RJ & Deputado & $1995-98$ & CBF e clubes & Lei Pelé \\
\hline
\end{tabular}




\begin{tabular}{|c|c|c|c|c|c|}
\hline Santana & & federal & & & \\
\hline $\begin{array}{l}\text { Darcísio } \\
\text { Perondi }\end{array}$ & $\begin{array}{l}\text { PMDB- } \\
\text { RS }\end{array}$ & $\begin{array}{l}\text { Deputado } \\
\text { federal }\end{array}$ & $1995-2015$ & $\begin{array}{l}\text { Federações e } \\
\mathrm{CBF}\end{array}$ & $\begin{array}{l}\text { Lei Pelé/ CPI CBF- } \\
\text { Nike }\end{array}$ \\
\hline $\begin{array}{l}\text { Eurico } \\
\text { Miranda }\end{array}$ & $\begin{array}{l}\text { PL/ } \\
\text { PPB-RJ }\end{array}$ & $\begin{array}{l}\text { Deputado } \\
\text { federal }\end{array}$ & 1990-2002 & $\begin{array}{l}\text { Clubes } \\
\text { CBF }\end{array}$ & $\begin{array}{l}\text { Lei Zico/ Lei Pelé/ } \\
\text { CPI CBF-Nike e } \\
\text { CPI do Futebol }\end{array}$ \\
\hline $\begin{array}{l}\text { Germano } \\
\text { Rigotto }\end{array}$ & $\begin{array}{l}\text { PMDB- } \\
\text { RS }\end{array}$ & $\begin{array}{l}\text { Deputado } \\
\text { federal }\end{array}$ & $1990-2002$ & Clubes & Lei Pelé \\
\hline $\begin{array}{l}\text { Inocêncio } \\
\text { Oliveira }\end{array}$ & $\begin{array}{l}\text { PFL/ } \\
\text { PL/ PR- } \\
\text { PE }\end{array}$ & $\begin{array}{l}\text { Deputado } \\
\text { federal }\end{array}$ & $1975-2015$ & Clubes & Lei Pelé \\
\hline José Janene & PP-PR & $\begin{array}{l}\text { Deputado } \\
\text { federal }\end{array}$ & 2003-06 & $\mathrm{CBF}$ & Timemania \\
\hline José Rocha & PFL-BA & $\begin{array}{l}\text { Deputado } \\
\text { federal }\end{array}$ & $2003-2010$ & $\mathrm{CBF}$ & $\begin{array}{l}\text { CPI CBF-Nike/ } \\
\text { Estatuto } \\
\text { Desporto e Projeto } \\
\text { de Lei } 5186\end{array}$ \\
\hline $\begin{array}{l}\text { Jovair } \\
\text { Arantes }\end{array}$ & $\begin{array}{l}\text { PSDB/ } \\
\text { PTB- } \\
\text { GO }\end{array}$ & $\begin{array}{l}\text { Vice- } \\
\text { presidente do } \\
\text { conselho } \\
\text { deliberativo } \\
\text { do Atlético } \\
\text { Goianiense/ } \\
\text { Deputado } \\
\text { federal }\end{array}$ & $1995-2015$ & Clubes & $\begin{array}{l}\text { Lei Pelé/ Lei de } \\
\text { Responsabilidade } \\
\text { Fiscal do Esporte }\end{array}$ \\
\hline $\begin{array}{l}\text { Leomar } \\
\text { Quintanilha }\end{array}$ & $\begin{array}{l}\text { PPB/ } \\
\text { PFL/ } \\
\text { PMDB- } \\
\text { TO }\end{array}$ & $\begin{array}{l}\text { Deputado } \\
\text { Federal/ } \\
\text { Senador }\end{array}$ & $1990-2011$ & $\begin{array}{l}\text { Federações e } \\
\mathrm{CBF}\end{array}$ & $\begin{array}{l}\text { Lei Pelé/ CPI do } \\
\text { Futebol/ } \\
\text { Timemania }\end{array}$ \\
\hline
\end{tabular}




\begin{tabular}{|c|c|c|c|c|c|}
\hline $\begin{array}{l}\text { Luciano } \\
\text { Bivar }\end{array}$ & PSL-PE & $\begin{array}{l}\text { Presidente } \\
\text { do Sport/ } \\
\text { Deputado } \\
\text { federal }\end{array}$ & 1999-2002 & Clubes & CPI CBF-Nike \\
\hline $\begin{array}{l}\text { Maguito } \\
\text { Vilela }\end{array}$ & $\begin{array}{l}\text { (PMDB- } \\
\text { GO) }\end{array}$ & $\begin{array}{l}\text { Ex-vice } \\
\text { presidente } \\
\text { da CBF/ } \\
\text { Dirigente do } \\
\text { Jataiense- } \\
\mathrm{GO} / \\
\text { Senador }\end{array}$ & 1999-2006 & CBF e clubes & $\begin{array}{l}\text { Lei Maguito Vilela/ } \\
\text { CPI do Futebol }\end{array}$ \\
\hline $\begin{array}{l}\text { Marcelo } \\
\text { Guimarães } \\
\text { Filho }\end{array}$ & PFL-BA & $\begin{array}{l}\text { Deputado } \\
\text { federal }\end{array}$ & 2003-06 & Clubes & $\begin{array}{l}\text { Estatuto do } \\
\text { Desporto e Projeto } \\
\text { de lei } 5186\end{array}$ \\
\hline $\begin{array}{l}\text { Márcio } \\
\text { Braga }\end{array}$ & $\begin{array}{l}\text { PMDB- } \\
\text { RJ }\end{array}$ & $\begin{array}{l}\text { Deputado } \\
\text { federal }\end{array}$ & 1983-1990 & $\begin{array}{ll}\text { Clubes } & \mathrm{e} \\
\text { jogadores } & \end{array}$ & Lei Zico \\
\hline $\begin{array}{l}\text { Marco } \\
\text { Antônio } \\
\text { Vicente }\end{array}$ & PTB-ES & $\begin{array}{l}\text { Presidente } \\
\text { da } \\
\text { Federação } \\
\text { do Espírito } \\
\text { Santo/ } \\
\text { Deputado } \\
\text { federal }\end{array}$ & $2002-05$ & Federações & Timemania \\
\hline $\begin{array}{l}\text { Mendes } \\
\text { Ribeiro } \\
\text { Filho }\end{array}$ & $\begin{array}{l}\text { PMDB- } \\
\text { RS }\end{array}$ & $\begin{array}{l}\text { Deputado } \\
\text { federal }\end{array}$ & 1995-2002 & Clubes & Lei Pelé \\
\hline $\begin{array}{l}\text { Pedro } \\
\text { Corrêa }\end{array}$ & PP-PE & $\begin{array}{l}\text { Deputado } \\
\text { federal }\end{array}$ & 2003-05 & $\mathrm{CBF}$ & Timemania \\
\hline $\begin{array}{l}\text { Ricardo } \\
\text { Gomyde }\end{array}$ & $\begin{array}{l}\text { PCdoB- } \\
\text { PR }\end{array}$ & $\begin{array}{l}\text { Deputado } \\
\text { federal }\end{array}$ & 1995-98 & Clubes & Lei Pelé \\
\hline
\end{tabular}




\begin{tabular}{|c|c|c|c|c|c|}
\hline $\begin{array}{l}\text { Ronaldo } \\
\text { Aragão }\end{array}$ & $\begin{array}{l}\text { PMDB- } \\
\text { RO }\end{array}$ & Senador & 1990-94 & $\mathrm{CBF}$ & Lei Zico \\
\hline Romário & PSB-RJ & $\begin{array}{l}\text { Deputado } \\
\text { federal/ } \\
\text { senador }\end{array}$ & $\begin{array}{l}\text { 2011-14/ } \\
2015-\end{array}$ & Jogadores & $\begin{array}{l}\text { Lei de } \\
\text { Responsabilidade } \\
\text { Fiscal do Esporte }\end{array}$ \\
\hline $\begin{array}{l}\text { Vicente } \\
\text { Cândido }\end{array}$ & PT-SP & $\begin{array}{l}\text { Deputado } \\
\text { federal/ } \\
\text { vice- } \\
\text { presidente } \\
\text { da } \\
\text { Federação } \\
\text { Paulista de } \\
\text { Futebol }\end{array}$ & 2011- & Federações & $\begin{array}{l}\text { Lei de } \\
\text { Responsabilidade } \\
\text { Fiscal do Esporte }\end{array}$ \\
\hline $\begin{array}{l}\text { Zezé } \\
\text { Perrella }\end{array}$ & $\begin{array}{l}\text { PFL- } \\
\text { MG }\end{array}$ & $\begin{array}{l}\text { Deputado } \\
\text { federal/ } \\
\text { Senador }\end{array}$ & $\begin{array}{l}\text { 1999-2002/ } \\
\text { 2011- }\end{array}$ & Clubes & $\begin{array}{l}\text { Lei Pelé/ Lei } \\
\text { Maguito Vilela }\end{array}$ \\
\hline
\end{tabular}

Alguns nomes ajudaram em questões pontuais, sendo considerados aqui parte da "bancada da bola" pois, em algum momento, tentaram ajudar diferentes grupos nas questões abordadas. No entanto, o destaque fica para alguns nomes frequentes, bastante atuantes, seja participando das discussões de várias questões, seja participando de uma ou duas questões específicas com muita intensidade, e acumulando cargos em entidades desportivas, ou mantendo relações com elas. Eurico Miranda talvez seja o maior exemplo. Foi vice-presidente, depois presidente do Vasco da Gama e exerceu vários mandatos como deputado federal, se posicionando e tentando barrar por diversas vezes o fim do passe e a criação do clube-empresa, na tramitação da Lei Zico e também da Lei Pelé, além de tentar barrar a instalação da CPI do Futebol e participar, como integrante, da CPI da CBF-Nike. Outros destaques que exerceram mandatos de deputados federais foram Darcísio Perondi, irmão do presidente da Federação Gaúcha de Futebol, Emídio Perondi, na época da Lei Pelé, e que recebeu doações da CBF para as eleições de 1998; Zezé Perrella, que foi presidente do Cruzeiro e tentou barrar o fim do passe, na tramitação da Lei Pelé; 
Jovair Arantes, exercendo mandato atualmente, ativo nas discussões da Lei de Responsabilidade Fiscal do Esporte e que já havia defendido os clubes na época da Lei Pelé e foi dirigente do Atlético Goianiense.

No caso dos senadores, dois nomes se destacam. Leomar Quintanilha, que foi presidente da Federação de Futebol do Tocantins, recebeu doações da CBF e foi relator do projeto da lei Pelé na Comissão de Constituição e Justiça, propondo amenizações no fim da lei do passe e a prerrogativa de os clubes poderem escolher se tornarem empresas ou não. Além dele, Maguito Vilela teve atuação bastante relevante. Foi dirigente do clube Jataiense, de Goiás e participou das discussões do projeto de Pelé, também tentando barrar questões como o fim do passe e medidas que pressionassem os clubes. Propôs mudanças importantes na lei aprovada, que diminuía os prejuízos dos clubes, tornando-se, inclusive nome da nova lei, que alterou a lei Pelé.

Os parlamentares que representam ou representaram interesses de grupos do meio futebolístico foram importantes, portanto, nos resultados finais que se deram após as diversas discussões em torno das mudanças no futebol brasileiro na arena política. Hoje, alguns nomes ainda se destacam, como Jovair Arantes, Vicente Cândido e Romário, que procuraram atuar constantemente nas discussões da Lei de Responsabilidade Fiscal do Esporte, os dois primeiros mais próximos de clubes, de federações e da $\mathrm{CBF}$, e o último mais próximo da defesa dos interesses dos jogadores e da imprensa esportiva.

\section{2) Atuação dos grupos de interesse}

O primeiro passo da pesquisa, em relação às duas áreas específicas que envolvem o processo de modernização do futebol no Brasil, as relações de trabalho entre atletas e clubes, e a administração destes, foi reconstituir o debate que se deu em diversos momentos, desde a idealização da Lei Zico - e alguns momentos importantes que a antecederam -, até os dias de hoje. Foi visto que houve transformações nas duas áreas, a primeira com mudanças mais profundas e a segunda com mudanças pontuais, que não alteraram incisivamente elementos centrais que envolvem a área. Além disso, 
foi visto também que os grupos de interesse atuaram no desenrolar das duas questões, de maneira decisiva, alterando o status quo de ambas, de maneiras distintas e com pesos diferentes de suas influências nelas.

Os grupos que aparecem na história dessas duas áreas se encaixam na definição de grupos de interesse aqui adotada. Tanto atletas, como clubes, federações e confederações se constituíram como conjuntos de indivíduos ou organizações que compartilharam características. Os clubes, as federações e a CBF contaram com organizações formais durante todo o tempo, enquanto os jogadores apenas em alguns momentos e todos procuraram, de maneira mais ou menos acentuada, influenciar as decisões públicas, para mudar o status quo ou preservá-lo, de acordo com seus interesses. Os jogadores não se organizaram de maneira tão incisiva, sendo representados pelos sindicatos estaduais e, posteriormente, criando uma associação nacional, mas participavam pouco dessas organizações. Apenas recentemente, com a criação do Bom Senso FC, que se formou uma mobilização maior e que pressiona mais os clubes, federações, confederações e poder público. Já os clubes, as federações e a CBF se organizaram praticamente o tempo todo, por meio de relações entre eles mesmo, com parlamentares, por meio de financiamento de campanhas ou relações corpo a corpo, e com outros atores, como instituições de ensino (FGV) e meios de comunicação (TV Globo).

A atuação dos grupos de interesse aqui analisados, ainda que possa não ter sido organizada tão minuciosamente quanto se costuma organizar, por exemplo, o setor industrial, o qual possui um procedimento sistemático de acompanhamento e pressão em relação às atividades legislativas que podem ser de seu interesse, através da vigilância das matérias que lhe dizem respeito, do acompanhamento das mesmas e suas alterações, da análise delas, da tomada de posição em relação a elas, da comunicação orientativa, divulgando sua posição, e do exercício de pressão (Mancuso, 2004), provocou uma atividade de pressão bastante significativa, com variações entre os diferentes grupos, ao longo do tempo.

A ação dos grupos se deu junto aos diversos atores, tanto em relação ao poder legislativo, algumas vezes diretamente, outras não, com os deputados, como em relação ao poder executivo, diretamente com a presidência ou com os ministérios, por vezes devido à proximidade ideológica, por vezes por meio de financiamentos de 
campanhas, ou apenas relações próximas por meio de reuniões, físicas ou não, conforme argumentou parte da literatura sobre grupos de interesse (Baird, 2012; Rasmussen e Lindeboom, 2013). Como outra parte da literatura (Pedersen, 2013) enfatizou, o próprio poder público chegou a convocar os grupos para debater as questões envolvidas, por meio de audiências, debates e seminários, que são meios explícitos de discussão. Mas também ocorreram relações menos aparentes, com proximidade entre o poder público e representantes de grupos.

Todas as políticas que envolveram os momentos-chave do processo de modernização do futebol brasileiro passaram por diversas fases, desde sua idealização, passando pela apresentação aos parlamentares, por sua tramitação nas diferentes casas, até suas aprovações ou rejeições por parte dos legisladores e do poder executivo e, finalmente, pela regulamentação e possíveis alterações. Os grupos de interesse buscaram atuar em todas elas, conforme argumenta a literatura (Mancuso, 2004; Ripley, 1995), por exemplo, nos casos da Lei Zico e da Lei Pelé, que já sofreram resistência antes mesmo de entrarem na pauta de votação da Câmara dos Deputados, assim como as CPIs, que foram alvos de tentativas de serem barradas, especialmente por Eurico Miranda. Outras sofreram mudanças após o processo de tramitação, como a Lei Pelé, que acabou sendo alterada por outra lei, a Maguito Vilela, em decorrência da insistência de grupos, como alguns clubes, federações e a CBF de colocar contrapartidas nas medidas que os desfavoreciam.

O que mais se quer destacar, no que diz respeito da relação com a literatura, é a inspiração teórica que a teoria das coalizões de militância provocou neste trabalho. Em primeiro lugar, a ideia das coalizões é utilizada aqui, mas ponderando que talvez o caso não seja exatamente como propõe o modelo de Sabatier e Jenkins Smith (1999), principalmente porque há compartilhamento de ideias sobre uma política, como o modelo prevê, no entanto, não se pode dizer, em todos os casos, que grupos se uniram com o objetivo específico de influenciar tal política. O caso mais próximo da ideia da coalizão é o da união entre CBF e federações, que partilharam ideias semelhantes e atuaram de maneira conjunta na defesa delas. Já a relação dos clubes com estes outros grupos não foi tão constante, pois alguns atuaram do outro lado, apoiando medidas modernizantes. A relação entre os outros grupos foi algo mais próximo a uma convergência de interesses, a qual levou alguns grupos a atuarem no mesmo sentido, 
mas não a se unirem para tal. Atuaram no mesmo sentido, mas não de maneira conjunta. No entanto, essa diferença em relação ao modelo não faz com que se abandone por completo a referência teórica.

Alguns grupos, como CBF e federações (por vezes os clubes também), e jogadores e meios de comunicação acabaram racionalizando suas preferências (Olson, 1999) e atuando, por vezes, de maneira conjunta, ao menos na conformidade de interesses. Esses exemplos de convergências de grupos podem ser vistos como um compartilhamento de visões muito próximas com relação a determinadas questões (Sabatier e Jenkins Smith, 1999), mesmo que os grupos não tenham se comportado de maneira engessada o tempo todo, seguindo estritamente os interesses envolvidos nessas convergências. Muitos clubes, por exemplo, se mostraram a favor de mudanças em suas estruturas administrativas, alguns deles até vendo de forma positiva a transformação em empresas. Também houve casos de jogadores que não concordavam com o fim do passe, apesar de o grupo que os representa, os sindicatos, se posicionar a favor. Já no caso das federações e da CBF, a convergência foi mais uniforme ao longo do tempo.

Ainda se pode dizer que os embates entre os grupos acontecem num processo de mudança de uma política, que é o processo de modernização do futebol brasileiro inserido no meio político, alvo de leis e políticas específicas durante um longo período de tempo, desde o final da década de 1980 até os dias de hoje.

No modelo de Sabatier e Jenkins Smith (1999), é importante, além das decisões dos poderes legislativo e executivo, o papel da comunidade científica, como acadêmicos, analistas e consultores, pois informações científicas podem ser uma boa base para dar legitimidade aos discursos das coalizões, criando novos paradigmas para determinados temas, que podem se tornar vigentes por um bom tempo. Os novos paradigmas podem estabelecer um novo sistema de valores, concretizados com a criação de elementos institucionais, como leis, decretos e políticas. No caso do processo aqui analisado, é difícil encontrar uma comunidade científica em torno de temas relacionados ao futebol. Mas, em geral, considera-se tudo aquilo que é feito no futebol europeu como "o certo", o modelo a ser seguido, o que não deixa de ser uma base para estabelecimento de novos paradigmas, que, no caso seria o da crescente associação do futebol ao mundo dos negócios, da racionalização e do profissionalismo. Estes elementos serem majoritários na Europa servia, e serve de base para o argumento de que aqui também deve ser assim. 
Quanto aos resultados decorrentes da reconstituição do debate das questões centrais da modernização do futebol no Brasil, no tocante às relações de trabalho, os atletas contaram com o apoio do governo, que estava empenhado em promover mudanças significativas, alterando o cenário anterior. As relações de trabalho entre clubes e atletas representavam um atavismo, uma relação que prendia os atletas aos clubes. Os jogadores, praticamente em nada, se equiparavam ao trabalhador comum brasileiro, já que não tinham seus direitos trabalhistas baseados na Consolidação das Leis Trabalhistas. Valia uma lei da década de 1970, de caráter anacrônico, que prendia os jogadores aos clubes a que eram ligados, não apenas por um contrato, com condições para a quebra do mesmo, mas pelo mecanismo do passe, que ia além dos limites do contrato, prevendo que os atletas só estariam livres aos 32 anos, e, mesmo que o contrato acabasse, a saída só poderia ser concretizada através do pagamento de um valor financeiro ao clube que possuísse o passe.

Desde a Lei Zico, houve bastante empenho de uma convergência de interesses, formada por governo - o propositor da mudança -, entidades representativas dos jogadores e também por alguns meios de comunicação, como jornais, que se mostravam favoráveis às demandas que beneficiavam os atletas. Essa convergência de interesses foi determinante nos resultados que se deram em todo o debate. Ela conseguiu, mesmo com resistências importantes da coalizão dos clubes, federações e $\mathrm{CBF}$, provocar mudanças significativas, que mudaram a realidade dos jogadores de futebol, equiparando-os, ainda que não totalmente, mas com grandes avanços, em direitos, ao trabalhador comum brasileiro, o que reafirma a hipótese lançada no início do trabalho. A Tabela 2, abaixo, ilustra resumidamente como se desenvolveu, ao longo do período estudado, a atuação dos grupos de interesse na questão das relações de trabalho. 
Tabela 2 - Grupos de interesse e relações de trabalho entre atletas e clubes

\begin{tabular}{|c|c|c|}
\hline Grupo de interesse & Formas de atuação & Resultados \\
\hline Clubes, federações e CBF & $\begin{array}{l}\text { Proximidade com } \\
\text { parlamentares, doações } \\
\text { para campanhas, reuniões } \\
\text { internas, reuniões com } \\
\text { governo }\end{array}$ & $\begin{array}{l}\text { Insucesso pontual } \\
\text { Prorrogação de prazos para } \\
\text { entrada em vigor de } \\
\text { medidas desfavoráveis, } \\
\text { amenização dos efeitos das } \\
\text { medidas, como a cláusula } \\
\text { penal (indenização nas } \\
\text { transferências). Em geral, } \\
\text { mais perdeu do que } \\
\text { ganhou. Fim do passe }\end{array}$ \\
\hline $\begin{array}{l}\text { Jogadores e associações } \\
\text { relacionadas }\end{array}$ & $\begin{array}{l}\text { Formação de entidades } \\
\text { para defesa dos interesses, } \\
\text { reuniões com governo e } \\
\text { parlamentares. Tiveram } \\
\text { apoio de jornalistas }\end{array}$ & $\begin{array}{l}\text { Sucesso definitivo } \\
\text { Aprovação de medidas } \\
\text { favoráveis, como liberdade } \\
\text { de trabalho. Em geral, } \\
\text { mais ganhou do que } \\
\text { perdeu. Fim do passe }\end{array}$ \\
\hline Meios de comunicação & $\begin{array}{l}\text { Discursos e textos } \\
\text { publicados; apoio ao } \\
\text { governo e aos atletas; } \\
\text { participação em debates, } \\
\text { audiências e seminários }\end{array}$ & $\begin{array}{l}\text { Sucesso definitivo } \\
\text { Aprovação de medidas } \\
\text { favoráveis, como o fim do } \\
\text { passe. Mais ganhou do que } \\
\text { perdeu }\end{array}$ \\
\hline $\begin{array}{l}\text { Governo (Não se trata de } \\
\text { um grupo de interesse. } \\
\text { Mas seus interesses } \\
\text { foram fundamentais) }\end{array}$ & $\begin{array}{l}\text { Proposição e aprovação de } \\
\text { leis, reunião com outros } \\
\text { grupos }\end{array}$ & $\begin{array}{l}\text { Aprovação de medidas } \\
\text { propostas. Mais ganhou do } \\
\text { que perdeu }\end{array}$ \\
\hline
\end{tabular}

Utilizando a classificação de sucessos e insucessos de Mancuso (2004), o argumento aqui é que os clubes, as federações e a CBF tiveram insucesso pontual na questão das relações de trabalho, porque acabaram tendo uma derrota significativa, já que o passe foi extinto e os jogadores não mais precisariam ficar ligados por muito tempo, mesmo a contragosto, aos clubes. No entanto, ao longo das decisões tomadas nessa área, considerando tramitação dos projetos, decisão das casas legislativas e 
vetos ou sanções da presidência, esse conjunto de grupos com interesses convergentes ( $\mathrm{CBF}$, clubes e federações) conseguiu que fossem prorrogados prazos de medidas desfavoráveis e que alguns efeitos de algumas medidas fossem amenizados, como no caso da cláusula penal, que fazia com que os clubes pudessem receber indenizações pelas transferências de atletas. Por outro lado, considera-se que os jogadores e os meios de comunicação tiveram sucesso definitivo, principalmente pela principal questão que os envolvia ter sofrido uma mudança significativa, com o fim do passe, que foi uma decisão final do poder público.

Já na questão da administração dos clubes, os jogadores pouco se envolveram para tentar realizar qualquer mudança ou para manter o status quo. Apenas com o crescimento do Bom Senso este grupo passou a pressionar mais para que os clubes alterassem suas formas de gerir o futebol e para que o governo levasse os dirigentes a tal objetivo. A forma como boa parte dos dirigentes administravam os clubes foi, ao longo do desenvolvimento do futebol no país, se tornando cada vez mais incompatível com as transformações pelas quais o esporte passava, tornando-se alvo do mercado, uma área de negócios de grandes números financeiros, que, portanto, acabaria gerando lucros e, consequentemente, tendo que mudar a maneira como eram tratados juridicamente e como eram administrados, aproximando-se mais das práticas empresariais. Não foram poucas as medidas institucionais tomadas pelo poder público para tentar mudar tal situação.

Foram propostas leis que alteravam o status jurídico das entidades desportivas que geravam lucro, leis estas que, ou diferiram em maior ou menor grau dos seus projetos originais, ou não foram respeitadas, quando em vigor, pelos clubes. Alguns até procuraram se adaptar, com mais ou menos sucesso. Também foram adotadas medidas, em alguns casos, também propostas leis, que criassem mecanismos para que os clubes pudessem pagar os impostos que deviam, através de renegociações de dívidas, que, para incentivar os clubes a aderir a elas, traziam benefícios a eles. Foi o caso da Timemania, bem como do Refis e da proposta atual da Lei de Responsabilidade Fiscal do Esporte.

No entanto, diferentemente do que aconteceu com o caso das relações de trabalho, não se formou uma convergência de interesses que atuasse de maneira incisiva no sentido da mudança. O governo atuou praticamente sozinho na questão da 
administração dos clubes. Não que este não seja ator muito forte, mesmo sozinho, pois conta com grandes recursos, como órgãos específicos da área fiscal, como a Procuradoria Geral da Fazenda Nacional. Mas não conseguiu trazer mudanças significativas. Por outro lado, pode-se dizer que formou-se uma convergência a favor do status quo, por uma parte dos clubes, aliada às federações, à CBF e à TV Globo. Essa coalizão, reafirmando a hipótese inicial do trabalho, aceitou pequenas mudanças - não sem receber benefícios em troca -, mas para que as coisas continuassem como estavam, com seus integrantes mantendo suas estruturas de poder e pagando as dívidas que possuem de maneira gradual, com contrapartidas favoráveis a eles, apesar de a tendência, com a aprovação da Lei de Responsabilidade Fiscal do Esporte, de se criar um cenário diferente. A Tabela 3 mostra, de maneira resumida, como foi a atuação dos grupos de interesse em relação à administração dos clubes. 
Tabela 3 - Grupos de interesse e administração dos clubes

\begin{tabular}{|c|c|c|}
\hline Grupo de interesse & Forma de atuação & Resultados \\
\hline Clubes, federações e CBF & $\begin{array}{l}\text { Proximidade com } \\
\text { parlamentares, doações } \\
\text { para campanhas, reuniões } \\
\text { internas, reuniões com } \\
\text { governo, relações com a } \\
\text { TV Globo }\end{array}$ & $\begin{array}{l}\text { Sucesso pontual parcial } \\
\text { Benefícios fiscais e } \\
\text { parcelamentos de dívidas } \\
\text { (Timemania, Refis e } \\
\text { LRFE), estruturas de poder } \\
\text { mantidas, apesar de } \\
\text { alguns bloqueios de } \\
\text { receitas e da obrigação de } \\
\text { apresentação dos balanços. } \\
\text { Mais ganhou do que } \\
\text { perdeu }\end{array}$ \\
\hline $\begin{array}{l}\text { Jogadores e associações } \\
\text { relacionadas }\end{array}$ & Bom Senso FC & $\begin{array}{l}\text { Insucesso pontual } \\
\text { Resultados ainda incertos, } \\
\text { mas deu força aos } \\
\text { interesses dos atletas. Por } \\
\text { enquanto, mais perdeu do } \\
\text { que ganhou }\end{array}$ \\
\hline $\begin{array}{l}\text { Governo (Não se trata de } \\
\text { um grupo de interesse, mas } \\
\text { seus interesses foram } \\
\text { fundamentais) }\end{array}$ & $\begin{array}{l}\text { Proposição e aprovação de } \\
\text { leis e medidas, reunião } \\
\text { com outros grupos, } \\
\text { incentivos fiscais }\end{array}$ & $\begin{array}{l}\text { Dívidas continuam, mas } \\
\text { programas e leis aprovadas } \\
\text { para receber valores dos } \\
\text { clubes. Perdeu e ganhou. } \\
\text { Difícil dizer em qual } \\
\text { proporção }\end{array}$ \\
\hline Meios de comunicação & $\begin{array}{l}\text { Discursos e textos } \\
\text { publicados; apoio ao Bom } \\
\text { Senso; no caso da Rede } \\
\text { Globo: relações, por meio } \\
\text { de reuniões com clubes, } \\
\text { incentivos financeiros } \\
\text { (detentora dos direitos de } \\
\text { transmissão e vendedora } \\
\text { das cotas de transmissão) }\end{array}$ & $\begin{array}{l}\text { Insucesso } \\
\text { pontual/Sucesso pontual } \\
\text { parcial } \\
\text { Medidas aprovadas com } \\
\text { pouco do que queriam. } \\
\text { Mais perderam do que } \\
\text { ganharam. No entanto, no } \\
\text { caso da Rede Globo, } \\
\text { mantem os direitos de } \\
\text { transmissão e ganha com } \\
\text { vitórias dos interesses dos } \\
\text { clubes }\end{array}$ \\
\hline
\end{tabular}


Parte dos clubes, CBF, federações tiveram sucesso pontual parcial, já que as decisões não provocaram mudanças que os afetassem, convergindo com seus interesses, não alterando as estruturas de poder das entidades, e recebendo benefícios fiscais e parcelamento de dívidas, apesar de terem que lidar com alguns bloqueios de receitas e divulgação de balanços. Os meios de comunicação tiveram tanto sucesso pontual parcial, já que a Rede Globo apoiava a convergência dos grupos clubes, CBF e federações, como também tiveram insucesso pontual, pois boa parte deles apoiava os jogadores. As medidas, até então, não foram favoráveis às demandas dos atletas e destes meios de comunicação, mas ainda estão em aberto, com possibilidade de se harmonizarem um pouco mais com tais demandas, com a lei aprovada em 2015.

Confirmam-se as hipóteses iniciais, portanto, de que houve mudanças significativas no caso das relações de trabalho e poucas mudanças no caso da administração dos clubes. Isso porque a atuação dos grupos de interesse, no primeiro caso, contou com a aproximação à agenda do governo, que se propôs a implantar medidas liberalizantes no futebol, caso claro da extinção do passe, resultando em sucesso definitivo da convergência de interesses entre jogadores e meios de comunicação nessa questão. Já no caso da administração dos clubes, não se tratou tanto de uma agenda do governo. Certamente, ele tentou regularizar a questão por várias vezes, por exemplo, com as propostas dos clubes se tornarem, facultativa ou obrigatoriamente, empresas, de terem que apresentar balanços anuais, bem como as federações e a CBF prestarem contas. Mas essas medidas acabaram não se consolidando de maneira tão clara quanto a extinção do passe, em razão de, até então, não se situarem como prioridade na agenda, ao menos esportiva, do governo, e também pelo forte empenho dos grupos alinhados para barrar tais mudanças, caso da convergência de interesses entre CBF e federações, e alguns clubes, que obtiveram sucesso pontual parcial nessa questão.

De qualquer maneira, considerando o longo prazo, mudanças significativas ocorreram no futebol brasileiro, consolidando o paradigma do futebol-negócio, o que seria uma visão moderna. E, nessa visão, está inserida a profissionalização por completo das relações de trabalho entre clubes e atletas, e a mentalidade empresarial na maneira de administrar os clubes, mesmo que apenas parte deles tenha procurado fazer tal adaptação. A tendência é que aumente o número de clubes que procurem 
realizar essa mudança, considerando também que, para o governo atual, está na agenda esportiva questões como a responsabilidade dos clubes por suas más administrações e o pagamento de suas dívidas. Além disso, se observa uma possibilidade de crescimento de clubes com administrações profissionais, próximas ao que seria o funcionamento de uma empresa, ainda mais após o período da Copa do Mundo, com alguns clubes adquirindo novos estádios, sempre muito parecidos com os modelos europeus, e procurando estabelecer gestões também próximas às da Europa, muito preocupadas com aumento de receitas, com marketing e resultados, mudando a relação dos próprios dirigentes com os clubes, dos atletas com os clubes e, por fim, dos próprios torcedores com suas agremiações, ficando estes mais próximos de uma relação de consumo do que de uma relação de torcida. Essas questões podem muito bem serem observadas no decorrer dos acontecimentos, e sugere-se que sejam alvos de pesquisas futuras, já que o processo de mudança no futebol brasileiro ainda está em andamento. 


\section{Considerações Finais}

Esta dissertação teve como objetivo principal analisar um processo de "modernização" do futebol brasileiro, caracterizado por transformações no esporte que o levaram de um fenômeno restrito ao lazer e à competição esportiva, ligado à paixão pelos clubes, para um fenômeno correspondente ao mundo do entretenimento, cada vez mais tomado pelo marketing e pelos negócios, envolvendo quantias relevantes de dinheiro, transformando aquilo que era apenas lazer, competição e paixão em atividade lucrativa e profissional.

A análise focou especialmente em dois aspectos do processo de modernização, as relações de trabalho entre clubes e atletas, e a administração dos clubes de futebol, os quais foram alvos de intensos debates no meio futebolístico e também fora dele, chegando à arena política. $\mathrm{O}$ primeiro aspecto aproximou $\mathrm{o}$ futebol ao profissionalismo, equiparando os jogadores aos trabalhadores comuns. Já o segundo, trouxe o esporte para mais perto do mundo dos negócios, passando de algo amador, de pequenas receitas, que pouco se envolvia com questões tributárias, para algo que passou a movimentar muito dinheiro, a gerar lucro, atrair investidores e, por consequência, ações de marketing, passando a se tornar um negócio, e, por tal, se envolvendo em questões tributárias, mudando sua relação com o Estado, sendo cada vez mais alvo deste, no sentido de ser cobrado por ele para que fosse taxado de acordo com a nova realidade.

Ambos foram discutidos dentro do tema geral da modernização, que não ficou restrito às discussões no meio do futebol, como se viu. A partir dos anos seguintes à redemocratização política do país, o esporte passou a ser assunto debatido também na política.

Já no início dos anos 1990, o projeto de lei que se tornaria a lei Zico propôs mudanças de grande porte na estrutura do futebol brasileiro, tentando extinguir a lei do passe, que acabava prendendo os atletas aos clubes, e tentando dar a possibilidade de os clubes se tornarem empresas. O segundo ponto foi aprovado após a tramitação do projeto, porém o primeiro ponto, após muita pressão de grupos de interesse 
contrários à medida, como alguns clubes, federações e a CBF, acabou sendo aprovado com diversas mudanças, adiando o fim do passe.

Após a lei Zico, o tema do esporte ganhou força e foi criado um ministério, que foi liderado por Pelé. Ele propôs uma nova lei, também propondo o fim da lei do passe e, dessa vez, propondo a obrigatoriedade da transformação dos clubes em empresas, o que foi rejeitado. Já o passe seria extinto, porém com um considerável período de carência para entrar em vigor.

Com o passe extinto, grupos contrários à medida continuaram se mobilizando e, por meio de parlamentares ligados a tais grupos, conseguiram algumas contrapartidas, principalmente pela aprovação da lei Maguito Vilela, de origem do senador de mesmo nome, que era ligado à $\mathrm{CBF}$ e a clubes de futebol. Ficou estabelecida a cláusula penal, que era uma recompensa aos clubes formadores e que investiram em atletas em caso de venda dos mesmos.

Essas foram as mudanças essenciais, mas o futebol continuou em pauta na arena política, sendo assunto de duas CPIs, para investigar os contratos da CBF com a Nike, na Câmara dos Deputados, e as entidades de administração do esporte, no Senado. As comissões apontaram uma série de irregularidades financeiras e administrativas, tanto por parte da $\mathrm{CBF}$, como das federações, dos clubes e também de empresários de futebol.

Daí, surgiu um novo projeto de lei, que resultou no Estatuto do Desporto, que, no governo Lula, deu as diretrizes da política de esportes nacional e se preocupou com questões administrativas das entidades esportivas, exigindo que elas apresentassem balanços financeiros anuais.

A partir daí, vieram outras medidas que diziam respeito à forma como clubes e federações eram administradas e como lidavam com as obrigações fiscais perante o governo federal. A Timemania, loteria esportiva, no governo Lula, apareceu para arrecadar dinheiro, numa tentativa de quitar as dívidas dos clubes, mas acabou não tendo o efeito esperado. Por fim, já no governo Dilma, foi criada a proposta da Lei de Responsabilidade Fiscal do Esporte, para refinanciar as dívidas dos clubes, com algumas contrapartidas a serem cumpridas por estes. Esta medida ainda está em debate atualmente, portanto, há de se esperar os resultados para uma análise mais 
profunda sobre o tema.

Todo a trajetória que foi reconstituída nesta dissertação teve como referência teórica o debate, dentro da ciência política, sobre os grupos de interesse. Em especial, a teoria das coalizões de defesa foi a base desta dissertação. A ideia das coalizões foi utilizada, ponderando que talvez o caso empírico não seja exatamente o que propõe o modelo de Sabatier e Jenkins Smith (1999), principalmente porque há compartilhamento de ideias sobre uma política, como o modelo prevê, no entanto, não se pode dizer, em todos os casos, que grupos se uniram com o objetivo específico de influenciar tal política. O caso mais próximo da ideia da coalizão é o da união entre CBF e federações, que partilharam ideias semelhantes e atuaram de maneira conjunta na defesa delas. Já a relação dos clubes com estes outros grupos não foi tão constante, pois alguns atuaram do outro lado, apoiando medidas modernizantes. A relação entre os outros grupos foi algo mais próximo a uma convergência de interesses, a qual levou alguns grupos a atuarem no mesmo sentido, mas não a se unirem para tal. Atuaram no mesmo sentido, mas não de maneira conjunta. No entanto, essa diferença em relação ao modelo não faz com que se abandone por completo a referência teórica.

As hipóteses que a dissertação confirmou foram que houve mudanças significativas no caso das relações de trabalho e poucas mudanças no caso da administração dos clubes. Isso porque a atuação dos grupos de interesse, no primeiro caso, contou com a aproximação à agenda do governo, que se propôs a implantar medidas liberalizantes no futebol, caso claro da extinção do passe, resultando em sucesso definitivo da convergência de interesses entre jogadores e meios de comunicação nessa questão.

Já no caso da administração dos clubes, não se tratou tanto de uma agenda do governo. Certamente, ele tentou regularizar a questão por várias vezes, por exemplo, com as propostas dos clubes se tornarem, facultativa ou obrigatoriamente, empresas, de terem que apresentar balanços anuais, bem como as federações e a CBF prestarem contas. Mas essas medidas acabaram não se consolidando de maneira tão clara quanto a extinção do passe, em razão de, até então, não se situarem como prioridade na agenda, ao menos esportiva, do governo, e também pelo forte empenho dos grupos alinhados para barrar tais mudanças, caso da convergência de interesses entre CBF e federações, e alguns clubes, que obtiveram sucesso pontual parcial nessa questão. 
Para analisar os resultados, foi utilizado o modelo de Mancuso (2004), sobre sucessos e insucessos dos grupos de interesse em determinadas questões de políticas públicas. A convergência de interesses entre os clubes, as federações e a CBF teve insucesso pontual na questão das relações de trabalho, porque acabaram tendo uma derrota significativa, já que o passe foi extinto e os jogadores não mais precisariam ficar ligados por muito tempo, mesmo a contragosto, aos clubes.

No entanto, ao longo das decisões tomadas nessa área, considerando tramitação dos projetos, decisão das casas legislativas e vetos ou sanções da presidência, esse conjunto de grupos com interesses convergentes $(\mathrm{CBF}$, clubes e federações) conseguiu que fossem prorrogados prazos de medidas desfavoráveis e que alguns efeitos de algumas medidas fossem amenizados, como no caso da cláusula penal, que fazia com que os clubes pudessem receber indenizações pelas transferências de atletas. Por outro lado, considera-se que os jogadores e os meios de comunicação tiveram sucesso definitivo, principalmente pela principal questão que os envolvia ter sofrido uma mudança significativa, com o fim do passe, que foi uma decisão final do poder público.

Na questão da administração dos clubes, a convergência de interesses entre parte dos clubes, e CBF e federações teve sucesso pontual parcial, já que as decisões não provocaram mudanças que os afetassem, convergindo com seus interesses, não alterando as estruturas de poder das entidades, e recebendo benefícios fiscais e parcelamento de dívidas, apesar de terem que lidar com alguns bloqueios de receitas e divulgação de balanços. A Rede Globo também teve sucesso pontual parcial, na medida em que apoiava essa convergência de grupos, pois interessa para ela, por uma questão de audiência, que os clubes possam se manter ativos, através da renegociação das suas dívidas. Já os jogadores e parte dos outros meios de comunicação tiveram insucesso pontual, já que as medidas, até então, não foram favoráveis às suas demandas, mas ainda estão em aberto, com possibilidade de se harmonizarem um pouco mais com tais demandas, com a lei aprovada em 2015.

Considerando o longo prazo, como propõe a teoria de Sabatier e JenkinsSmith (1999), mudanças significativas ocorreram no futebol brasileiro, consolidando o paradigma do futebol-negócio, que seria a visão moderna do esporte. Nessa visão, está inserida a profissionalização por completo das relações de trabalho entre clubes e 
atletas, e, por mais que ainda não esteja perfeitamente ajustado ao pensamento do futebol moderno, o ponto da administração dos clubes dá indicações de que pode se ajustar a este pensamento, considerando que, para o governo atual, está na agenda esportiva questões como a responsabilidade dos clubes por suas más administrações e o pagamento de suas dívidas.

Além disso, se observa uma possibilidade de crescimento de clubes com administrações profissionais, próximas ao que seria o funcionamento de uma empresa, ainda mais após o período da Copa do Mundo, com alguns clubes adquirindo novos estádios, sempre muito parecidos com os modelos europeus, e procurando estabelecer gestões também próximas às da Europa, muito preocupadas com aumento de receitas, com marketing e resultados, mudando a relação dos próprios dirigentes com os clubes, dos atletas com os clubes e, por fim, dos próprios torcedores com suas agremiações, ficando estes mais próximos de uma relação de consumo do que de uma relação de torcida.

A sugestão é que essas questões sejam observadas no decorrer dos acontecimentos, e sejam alvos de pesquisas futuras, já que o processo de mudança no futebol brasileiro ainda está em andamento e pode ser foco de um estudo comparativo entre o processo de modernização do futebol aqui no Brasil e em outros países que já consolidaram tal processo e, inclusive, serviram de modelo para o futebol brasileiro. 


\section{Referências Bibliográficas}

AIDAR, Antônio Carlos Kfouri e FAULIN, Evandro Jacóia. "Futebol e Desenvolvimento Socioeconômico.” In: Cadernos Ebape. Br, v. 4, n. 4, Dez. 2006.

ALVES, J. A. B.; PIERANTI, O. P. O Estado e a Formulação de uma Política Nacional de Esporte no Brasil. RAE - eletrônica, v. 6, n. 1, janeiro-junho, 2007.

ALBINO, José Coelho de Andrade; CARRIERI, Alexandre de Pádua; FIGUEIREDO, Diego; SARAIVA, Frederico Heitmann; e BARROS, Frederico Luiz Ribeiro Silva. "Sport Club Internacional e a constituição da identidade corporativa de 'clubeempresa"”. O\&S, v.16, n.48, Janeiro/Março 2009.

AZEVEDO, Paulo Henrique; BARROS, Jônatas de França; e SUAIDEN, Samir. "Caracterização do Perfil do Gestor Esportivo dos Clubes da Primeira Divisão de Futrbol do Distrito Federal e suas Relações com a Legislação Esportiva Brasileira. R. da Educação Física/UEM. Maringá, v.15, n.1, p. 33-42, 1 Sem. 2004.

BAIRD, Marcello Fragano. O lobby na regulação da propaganda de alimentos da Agência Nacional de Vigilância Sanitária-Anvisa. Diss. Universidade de São Paulo, 2012.

BOUDENS, Emile. “A Lei Pelé Não Existe Mais”. Consultoria Legislativa. Brasília. Outubro de 2000.

BOURDIEU, Pierre. Questões de sociologia. Rio de Janeiro: Marco Zero, 1983.

CADERNOS FGV PROJETOS “Futebol e desenvolvimento socioeconômico". Junho/Julho 2013; Ano 8; No 22; ISSN 19844883.

CHAIM, Aníbal Renan Martinot. "A bola e o chumbo: futebol e política nos anos de chumbo da ditadura militar brasileira". Dissertação de Mestrado. Faculdade de Filosofia, Letras e Ciências Humanas. Universidade de São Paulo, São Paulo, 2014.

CHIARIONI, Bruno e KROEHN, Márcio. Onde o esporte se reinventa: histórias e bastidores dos 40 anos de Placar. Primavera Editorial. São Paulo, 2010. pp. 147-192.

CORREIA, Carlus Augustus Jourand. As vozes do gramado: relato de ex-atletas sobre a formação do Sindicato de Futebolistas Profissionais do Rio de Janeiro (1971- 
1982) . Esporte e Sociedade. ano 5, n 15, Jul.2010/Out.2010

CORREIA DE MELO, Bruno Herrlein; CORREIA DE MELO, Pedro Herrlein. A Lei Pelé e o fim do "passe" no desporto brasileiro. In: Âmbito Jurídico, Rio Grande, IX, n. 35, dez 2006. Disponível em: < http://www.ambitojuridico.com.br/site/index.php?artigo_id=1523\&n_link=revista_artigos_leitura

COSTA, Carlos Everaldo Silva da e SILVA, Rosimeri Carvalho da. "Empresarização e controle organizacional: um estudo nos clubes de futebol em Santa Catarina".

CRUZ, Antonio Holzmeister Oswaldo. "A virada econômica do futebol: observações a partir do Brasil, Argentina e uma Copa do Mundo". Rio de Janeiro. 2010.

DANIEL, Pedro. “7o Valor das Marcas dos Clubes Brasileiros”. BDO. 2014.

FLORENZANO, José Paulo. Afonsinho e Edmundo: a rebeldia no futebol brasileiro. São Paulo: Musa, 1998.

GASPARETO, Thadeu Miranda. "O futebol como negócio: uma comparação financeira com outros segmentos”. Rev. Brasi. Ciênc. Esporte, Florianópolis, v.35, n.4, p. $825-845$, out/dez. 2013

GIGLIO, Sérgio Settani e RUBIO, Kátia. "Futebol profissional: o mercado e as práticas de liberdade". Rev Bras Educ Fís Esporte, (São Paulo) Jul-Set. 2013; 27(3):387-400

GONÇALVES, Julio Cesar de Santana e CARVALHO, Cristina Amélia. "A mercantilização do futebol brasileiro: instrumentos, avanços e resistências". Cadernos EBAPE. BR, v.4, n.2, Jun. 2006.

GURGEL, Anderson. Futebol S.A. - A Economia em Campo. São Paulo: Editora Sairava, 2006.

HAAG, Fernanda Ribeiro. "Futebol e o giro neoliberal: apontamentos e o caso brasileiro". PODIUM: Sport, Leisure and Tourism Review, São Paulo, v.2, n.1, p. 57 80, jan./jun. 2013.

HAJER, Maarten A (1993). "Discourse Coalitions and the Institutionalization of Practice: The Case of AcidRain in Britain." In: The Argumentative Turn, ed. FISCHER, F. and FORESTER, J. Durham, NC: Duke University Press, 43-76;

HIRATA, Edson e JUNIOR, Edson Archanjo Freitas Junior. "Bastidores do Jogo: as interferências na elaboração da Lei Pelé. Projeto História, São Paulo, n. 49, Abr. 2014. 
JONES, Michael and McBETH, Mark (2010). "Narrative Policy Framework: Clear Enough to be Wrong?" Policy Studies Journal38.2: 329-353;

KINGDON, John. Agendas, alternatives, and public policies. New York: Longman, 1995, capitulos 49 .

LEONCINI, Marvio Pereira e SILVA, Márcia Terra da. "Entendendo o futebol como um negócio: um estudo exploratório”. Gest. Prod. v.12 n.1 São Carlos jan./abr. 2005.

LIMONGI, Fernando e FIGUEIREDO, Argelina Cheibub. (1998), "Bases

Institucionais do Presidencialismo de Coalizão". Lua Nova, no 44.

MANHÃES, Eduardo Dias - 1986 - Política de Esportes no Brasil - Graal, Rio de Janeiro.

MANCUSO, W. P. 2004. O lobby da indústria no Congresso Nacional : empresariado e política no Brasil contemporâneo. Dados, Rio de Janeiro, v. 47, n. 3, p. 505-547. Disponível em : http://www.scielo.br/pdf/dados/v47n3/ a03v47n3.pdf.

MARQUES, Daniel Siqueira Pitta. “Administração de Clubes de Futebol Profissional e Governança Corporativa: um Estudo de Casos Múltiplos com Clubes do Estado de São Paulo”. Dissertação de Mestrado FEA-USP, São Paulo, 2005.

MARQUES, Renato Francisco Rodrigues; GUTIERREZ, Diego Monteiro; e ALMEIDA, Marco Antônio Bettine de. O SUB-CAMPO DO FUTEBOL: PRESIDENTES DE CLUBES EM FOCO. Universidade de São Paulo - USP, São Paulo - Brasil.

MARTINS, Mariana Zuaneti.'Democracia Corinthiana: sentidos e significados da participação dos jogadores”. Dissertação de Mestrado. Faculdade de Educação Física. Unicamp, Campinas, 2012.

McBETH, SHANAHAN, JONES. (2005). "The Science of Storytelling: Measuring Policy Beliefs in Greater Yellowstone". In: Society and Natural Resources 18: 41329. 
McBETH, SHANAHAN, ARNELL, HATHAWAY (2007). "The Intersection of Narrative Policy Analysis and Policy Change Theory" In: Policy Studies Journal 35.1: 87-108;

MELO FILHO, Álvaro. O Desporto na Ordem Jurídico-Constitucional Brasileira. São Paulo: Malheiros, 1995.

MEZZADRI, F.M. et al. "As interferências do Estado brasileiro no futebol e o estatuto de defesa do torcedor”. Rev. bras. Educ. Fís. Esporte, São Paulo, v.25, n.3, p.407-16, jul./set. 2011.

OLSON, Mancur. A logica da acao coletiva. Sao Paulo: EDUSP, 1999. Capitulos 1, 2, 5 e 6.

OURIQUES, Nilso. "O gol contra do rei: a Lei Pelé e suas consequências". Motrivivência, Ano XI, n.12, maio 1999.

PRONI, Marcelo Weishaupt. "Esporte Espetáculo e Futebol Empresa". Tese de doutorado apresentada à Faculdade de Educação Física da Universidade Estadual de Campinas. 1998

PEDERSEN, Helene Helboe (2013): Is measuring interest group influence a mission impossible? The case of interest group influence in the Danish parliament. In: Int Groups Adv 2 (1), S. 27-47.

PIERSON, Paul. "Public Policies as Institutions". In: SKOWRONEK, Stephen; GALVIN, Daniel; SHAPIRO, Ian (eds). Rethinking Political Institutions: The Art of the State, New York: New York University Press, 2006.

RALISCH, Guilherme e REBEHY, Perla Calil Pongeluppe Wadhy.Análise das decisões financeiras de clubes de futebol brasileiros. Faculdade de Economia, Administração e Contabilidade de Ribeirão Preto, USP, SP

RASMUSSEN, Anne and LINDEBOOM, Gert-Jan. Interest group-party linkage in the twenty-first century: Evidence from Denmark, the Netherlands and the United Kingdom. European Journal of Political Research 52: 264-289, 2013.

REVISTA PIAUÍ, Edição 19. Eurico, \#@ *!. Rio de Janeiro, abril de 2008.

REZENDE, Amaury José; DALMÁCIO, Flávia Zoboli; e PEREIRA, Carlos Alberto. A Gestão de Contratos de Jogadores de Futebol: uma Análise sob a Perspectiva da Teoria da Agência - O Caso do Clube Atlético Paranaense. Revista de Contabilidade e Controladoria, ISSN 1984-6266. Universidade Federal do Paraná, Curitiba, v. 2, n.3, p.95-123, set./ dez. 2010

RIPLEY, Randall. "Stages of the policy process". Daniel C. McCool (ed.). Public 
policy theories, models, and concepts: an anthology. New Jersey: Prentice Hall, 1995.

RODRIGUES, Francisco Xavier Freire. "A Lei Pelé e as Negociações de Jogadores de Futebol no Brasil". XIV CISO - Econtro de Ciências Sociais do Norte e Nordeste, GT 25 - Esporte e Sociedade. Recife, 2009.

ROE, Emery (1994). Narrative Policy Analysis: Theory and Practice. Durham, CT:

Duke University Press;

SABATIER, Paul; JENKINS-SMITH, Hank. "The advocacy coalition framework: an assessment". Paul Sabatier (ed.) - Theories of the policy process - Boulder: Westview Press, 1999.

SANTOS, Luiz Marcelo Vídero Vieira. "A evolução da gestão no futebol brasileiro". Dissertação de Mestrado em Administração Pública defendida na EAESP-FGV. Maio de 2002.

SANTOS, Fabiano e ALMEIDA, Acir. "Teoria Informacional e a Seleção de Relatores na Câmara dos Deputados". DADOS - Revista de Ciências Sociais, Rio de Janeiro, Vol. 48, n. 4, 2005, pp. 693 a 735.

SARMENTO, Carlos Eduardo. A regra do jogo: uma história institucional da CBF. Rio de Janeiro: FGV, 2006.

SHANAHAN, JONES, McBETH (2011). "Policy Narratives and Policy Processes" In: Policy Studies Journal 39.3: 535-561;

SILVA, Thiago M. da. A Bancada da Bola no Legislativo carioca: concepções, evidências e estratégias de uma representação singular. Rio de Janeiro: Fundação Getulio Vargas, 2013.

SOMMOGI, Amir. Finanças dos Clubes de Futebol do Brasil em 2011 e 2012. BDO, Maio de 2012.

Evolução das finanças dos clubes brasileiros- 2003-2012. Janeiro de 2013.

SOUZA, Fábio Augusto Pera de e ANGELO, Claudio Felisoni de. "O fim do passe e seu impacto sobre o desequilíbrio competitivo entre as equipes de futebol”. R.Adm., São Paulo, v.40, n.3, p.280-288, jul./ago./set. 2005 
SOUZA, Gabriel Menandro Evangelista de. "Adoção do Regime de Empresa e o Futebol Profissional. Monografia apresentada como requisito para conclusão do curso de bacharelado em Direito do Centro Universitário de Brasília. BRASÍLIA. 2005

SPESOTTO, Rubens Eduardo Nascimento. "Futebol profissional e administração profissional". Brasília. 2008

STONE, Deborah. (2002). Policy Paradox: The Art of Political Decision Making. Revised Edition, 3rd ed. New York: W. W. Norton;

VALENTE, Rafael e SERAFIM, Maurício C. "Gestão Esportiva: Novos Rumos Para o Futebol Brasileiro”. Rae Documento, vol. 46, n. 3, Jul./Set. 2006.

\section{Leis}

BRASIL. Lei no 6.354, de 02.09.76. Dispõe sobre as relações de trabalho do at profissional de futebol e dá outras providências.

BRASIL. Lei no 8.672, de 06.07.93. Institui normas gerais sobre desportos (Lei Zico).

BRASIL. Resolução/INDESP no 1, de 17.10.96. Regulamenta o art. 26 da Lei no 8.672, de 06.07.93, que institui normas gerais sobre desportos e dá outras providências.

BRASIL. Projeto de lei no 2.437 , de 1996. Dispõe sobre a cessão de contrato de trabalho de atleta profissional de futebol e dá outras providências.

BRASIL. Lei no 9.615, de 24 de março de 1998. Institui normas gerais sobre desporto e dá outras providências. Diário Oficial da República Federativa do Brasil

BRASIL. Decreto no 2.574, de 29.04.98. Regulamenta a Lei no 9.615, de 24.03.98.

BRASIL. Lei no 9.981, de 14.7.2000 - Altera dispositivos da Lei no 9.615, de 24.3.2000.

BRASIL. Medida Provisória no 39, de 14 de junho de 2002. Altera a Lei no 9.615 de 24 de março de 1998 que institui normas gerais sobre desporto e dá outras providências. Diário Oficial União, Brasília, no 216, Seção 1, p. 108, 7 de novembro de 2002.]

BRASIL. Medida Provisória No 79, de 27 de novembro de 2002. Dispõe sobre o direito ao ressarcimento dos custos de formação de atleta não profissional e a exploração comercial da imagem do atleta profissional, impõe vedações ao exercício de cargo ou função executiva em entidade de administração de desporto profissional, fixa normas de segurança nos estádios, adapta o tratamento diferenciado do desporto 
profissional à Lei no 10.406 , de 10 de janeiro de 2002 - Código Civil, estabelece diretrizes para o cumprimento da obrigação constante do art. 46-A da Lei n- 9.615, de 24 de março de 1998, altera o art. $8^{\text {o }}$ da Lei $\mathrm{n}^{\mathrm{o}}$ 10.359, de 27 de dezembro de 2001, e dá outras providência

BRASIL. Lei no 10.671, de 15 de maio de 2003. Dispõe sobre o Estatuto de Defesa do Torcedor e dá outras providências . Presidência da República, Casa Civil, seção Legislação, Leis. Publicado no Diário Oficial da União em 16/05/2003. Disponível em: 〈http://www.planalto.gov.br/ccivil/leis/2003/L10.671.htm>.

BRASIL. Projeto de Lei n. 5186/2005 - do Poder Executivo - que "altera a Lei ${ }^{\circ}$ 9.615, de 24 de março de 1998, que institui normas gerais sobre desporto e dá outras providências".

BRASIL. Lei $N^{o} 11.345$, de 14 de setembro de 2006. Dispõe sobre a instituição de concurso de prognóstico destinado ao desenvolvimento da prática desportiva, a participação de entidades desportivas da modalidade futebol nesse concurso e o parcelamento de débitos tributários e para com o Fundo de Garantia do Tempo de Serviço - FGTS; altera as Leis $\mathrm{n}^{\mathbf{0 s}}$ 8.212, de 24 de julho de 1991, e 10.522, de 19 de julho de 2002; e dá outras providências.

\section{Documentos Oficiais}

BRASIL. Diário Oficial da Câmara dos Deputados. 21 de novembro de 1995. pp. 5837-5843

27 de setembro de 1997. pp. 30038-30073

29 de novembro de 1997. pp. 38984-38988

10 de dezembro de 1997. pp. 41080-41085

11 de dezembro de 1997. pp. 41426-41503

CÂMARA DOS DEPUTADOS. Comissão Parlamentar de Inquérito Destinada a Apurar a Regularidade do Contrato Celebrado entre a CBF e a Nike. Brasília, junho de 2001.

SENADO FEDERAL. Relatório Final da Comissão Parlamentar de Inquérito. Criada por meio do Requerimento n. 497, de 2000-SF, "destinada a investigar fatos envolvendo as associações brasileiras de futebol”. Brasília, 2001

\section{PRONUNCIAMENTOS}

__Artur da Távola (PSDB), em 19 de janeiro de 1998, no Senado Federal. __Leomar 
Quintanilha (PPB), em 17 de janeiro de 1997, no Senado Federal. REQUERIMENTOS NA CÂMARA DOS DEPUTADOS __Eurico Miranda (PPB), em 7 de outubro de 1997.

__Germano Rigotto (PMDB), em 22 de outubro de 1997.

__Sandra Starling (PT), em 12 de novembro de 1996.

_ Vários Autores, em 10 de dezembro de 1997.

\section{Internet}

http://acervo.estadao.com.br

$\underline{\text { http://acervo.folha.com.br }}$

http://atletaspelobrasil.org.br/carta-aberta-aos-candidatos-a-presidencia/

http://blogdocitadini.com.br/?p=5060

http://blogdojuca.uol.com.br/2014/07/o-que-quer-o-bom-senso-fc-da-nova-lei/

http://blogdojuca.uol.com.br/2014/09/gol-dos-atletas-do-brasil/

http://blogdojuca.uol.com.br/2014/09/projeto-protege-jogadores-de-futebol-emformacao/

http://blogdojuca.uol.com.br/2014/10/carta-aberta-aos-candidatos-a-presidencia-darepublica/

http://blogdojuca.uol.com.br/2014/10/impasse-na-lei-da-responsabilidade-fiscal-doesporte/ 
http://blogdojuca.uol.com.br/2014/10/os-ultimos-assaltos-para-a-lei-daresponsabilidade-fiscal-no-eaporte/

http://blogdojuca.uol.com.br/2014/11/o-bom-senso-fc-na-casa-civil/

http://blogdojuca.uol.com.br/2014/12/assim-age-a-cartolagem/

http://blogdojuca.uol.com.br/2014/12/a-lrfe-nas-maos-da-casa-civil/

http://blogdojuca.uol.com.br/2014/12/gambiarra-da-cartolagem-tem-chance-zero-devigorar/

http://blogdojuca.uol.com.br/2014/12/houve-avanco-na-discussao-da-lei-daresponsabilidade-fiscal-do-esporte/

http://blogdojuca.uol.com.br/2014/12/lei-da-divida-dos-clubes-ainda-nao-temaprovacao-do-bom-senso-fc/

http://cadernodecampo.com/2014/07/28/5-pontos-fundamentais-da-lei-deresponsabilidade-doesporte/?utm_content=buffer05041\&utm_medium=social\&utm_source=twitter.com\& $\underline{\text { utm_campaign=buffer }}$

http://content.espn.com.br/assets/pdf/atletas-bom-senso-emendasirfe.pdf?_ga=1.33043902.1836422292.1398698094

http://espn.uol.com.br/noticia/430123 lei-de-responsabilidade-fiscal-entenda-o-queisso-muda-no-seu-clube

http://espn.uol.com.br/noticia/430264_so-com-previdencia-lei-rebaixaria-18-dos-20times-da-serie-a 
http://espn.uol.com.br/noticia/430305 bom-senso-apresenta-emendas-e-romariocompra-briga-com-jogadores-sobre-a-lei-das-dividas-dos-clubes

http://espn.uol.com.br/noticia/430332_governo-promete-contraproposta-ao-bomsenso-e-votacao-deve-acontecer-em-setembro

http://espn.uol.com.br/noticia/430365 juro-camarada-e-prazo-fazem-governo-travarajuda-a-clubes

http://espn.uol.com.br/noticia/431880_sao-paulo-deve-trocado-para-governo-atletico$\underline{\text { mg-fortuna }}$

http://espn.uol.com.br/noticia/432419_caixa-amplia-patrocinio-a-torneios-da-cbfespecialistas-dizem-que-e-dinheiro-publico

http://esporte.uol.com.br/futebol/ultimas-noticias/2014/08/06/cbf-usa-series-c-e-dpara-ampliar-alcance-geografico-de-lobby-do-proforte.htm

http://esporte.uol.com.br/futebol/ultimas-noticias/2014/08/06/em-reuniao-na-cbfglobo-defende-lei-que-refinancia-dividas-de-clubes.htm

http://esportefino.cartacapital.com.br/lei-de-responsabilidade-fiscal-do-esporteameaca-o-futebol/

http://esportes.estadao.com.br/noticias/futebol,receitas-dos-clubes-brasileirosatingem-r-3-1-bilhoes-mas-dividas-sobem, 1067228

http://www1.folha.uol.com.br/esporte/2014/09/1522881-fifa-decide-banirinvestidores-em-compra-de-jogadores.shtml?cmpid=\%22facefolha $\% 22$ 
http://g1.globo.com/politica/noticia/2014/07/governo-espera-aprovar-lei-fiscal-dosclubes-ate-setembro-diz-secretario.html

http://www.lancenet.com.br/minuto/MP-Profut-aprovadaSenado_0_1393060830.html http://www.pgfn.fazenda.gov.br/divida-ativa-da-uniao/todos-os-servicos/informacoese-servicos-para-pessoa-fisica/copy_of_parcelamentos/timemania/?searchterm=futebol

http://www.pgfn.fazenda.gov.br/divida-ativa-da-uniao/todos-os-servicos/informacoese-servicos-para-pessoa-fisica/copy_of_parcelamentos/lei-nb0-11-941-2009-mp-449

http://www.pgfn.fazenda.gov.br/divida-ativa-da-uniao/todos-os-servicos/informacoese-servicos-para-pessoa-fisica/copy_of_parcelamentos/refis

http://www.pgfn.fazenda.gov.br/divida-ativa-da-uniao/todos-os-servicos/informacoese-servicos-para-pessoa-fisica/copy_of_parcelamentos/mp-470-2009

http://placar.abril.com.br/revista/edicao-1301

http://placar.abril.com.br/revista/edicao-1317

http://www.receita.fazenda.gov.br/PessoaFisicaeJuridica/ParcelamentoLei11941/Defa $\underline{\text { ult.htm }}$

http://www12.senado.leg.br/noticias/materias/2015/08/06/mp-do-futebol-esancionada-com-vetos

http://www2.camara.leg.br

$\underline{\text { http://presidencia.gov.br }}$

http://www.senado.gov.br 
